University of Pennsylvania Carey Law School

Penn Law: Legal Scholarship Repository

Faculty Scholarship at Penn Law

$5-2002$

\title{
The Thirteenth Amendment and Slavery in the Global Economy
}

Tobias Barrington Wolff

University of Pennsylvania Carey Law School

Follow this and additional works at: https://scholarship.law.upenn.edu/faculty_scholarship

Part of the Civil Rights and Discrimination Commons, Constitutional Law Commons, Human Rights Law Commons, International Humanitarian Law Commons, and the Labor and Employment Law Commons

\section{Repository Citation}

Wolff, Tobias Barrington, "The Thirteenth Amendment and Slavery in the Global Economy" (2002). Faculty Scholarship at Penn Law. 2709.

https://scholarship.law.upenn.edu/faculty_scholarship/2709

This Article is brought to you for free and open access by Penn Law: Legal Scholarship Repository. It has been accepted for inclusion in Faculty Scholarship at Penn Law by an authorized administrator of Penn Law: Legal Scholarship Repository. For more information, please contact PennlawIR@law.upenn.edu. 


\title{
THE THIRTEENTH AMENDMENT AND SLAVERY IN THE GLOBAL ECONOMY
}

\author{
Tobias Barrington Wolff*
}

With increasing frequency, U.S. firms are carrying on their foreign operations through the exploitation of involuntary or slave labor. As a result, slavery has once again become an active component of some American industries. The Thirteenth Amendment to the Constitution proclaims that slavery shall not exist within the United States. But does the Amendment prohibit U.S. firms from exploiting foreign slave labor? An answer to that question will require a reexamination of the range of activities in American industry-and American participation in global industry—that the Amendment reaches. This Article begins that task. It analyzes the history of slavery and the slave trade in America in order to identify the principles that lie at the core of the Thirteenth Amendment. It describes how the Court has translated these core principles into a changing industrial context once before, in response to the rise of domestic peonage arrangements in the nineteenth and early twentieth centuries. It then offers a model for translating these same core principles into the emerging context of the global economy and, in the process, lays the foundation for a more modern and salient Thirteenth Amendment jurisprudence.

\section{INTRODUCTION}

The Thirteenth Amendment to the U.S. Constitution provides that "Neither slavery nor involuntary servitude, except as a punishment for crime whereof the party shall have been duly convicted, shall exist within the United States, or any place subject to their jurisdiction." Its language is capacious and its mandate broad. The prohibition embodied in the Amendment, not limited to the form of chattel slavery peculiar to pre-Civil War America, forbids almost all forms of compelled labor within the physical bounds of the United States and its possessions. But what of slave labor outside U.S. territory? When U.S. citizens participate in slave practices in foreign jurisdictions, does the Thirteenth Amendment im-

* Assistant Professor of Law, University of California Law School at Davis; J.D., Yale Law School, 1997; B.A., Yale University, 1992. I am especially grateful to Joel Paul, whose encouragement is largely responsible for the existence of this article; to Stephen Best, whose constant willingness to hear my thoughts in embryonic form is as indulgent as it is invaluable; and to Robert Paul Wolff, who reviewed the many drafts that preceded this finished product with a patience that one could only ask of a parent. Sincere thanks also go to Diane Amann, Kevin Bales, Alan Brownstein, Anupam Chander, Dick Fallon, Myriam Gilles, Jack Goldsmith, Ryan Goodman, Jill Hasday, Kevin Johnson, Larry Kramer, Gerard Magliocca, John Oakley, Charles Ogletree, Spencer Overton, Saskia Sassen, Madhavi Sunder, Eric Stone, Leti Volpp, and Cynthia Griffin Wolff for their valued comments and criticism, and to Dan Murphy, who provided superb research assistance. Finally, Laurence Borten provided outstanding editorial support.

1. U.S. Const. amend. XIII, $\S 1$. 
pose any interdiction? Can a U.S. citizen own a slave, so long as he does not bring the enslaved person to American shores?

These questions are emerging as matters of great importance, for the participation of U.S. citizens in foreign slave practices is on the rise. With increasing frequency, U.S.-based multinational corporations are carrying on their operations in some countries through the deliberate exploitation of involuntary or slave labor. The globalization of industry has carried with it a globalization of labor exploitation, occurring outside the ordinary jurisdiction of U.S. enforcement authorities. In countries such as Burma, Mauritania, Pakistan, and Ivory Coast, outright practices of slave labor have arisen, in varying forms and with varying levels of corporate involvement. ${ }^{2}$ American participation in such exploitation is often carried out indirectly - through intermediaries, with plausible deniability. And yet the abuse of foreign laborers under conditions of slavery is assuming an increasingly important position in the economics of some U.S. industries-notable among them the resource extraction and manufacturing industries, where the use of cheap, expendable, involuntary labor has markedly increased profitability.

This development in the foreign labor practices of U.S. entities heralds a new era of challenge and transformation for the Thirteenth Amendment and its prohibition on the existence of slavery or involuntary servitude. It has become necessary to reexamine the range of activities in American industry, and American participation in global industry, that the Amendment reaches. The inquiry is long overdue. Despite the importance of the principle that the Thirteenth Amendment embodies, its doctrinal landscape is severely underdeveloped and has not yet been meaningfully translated into the present industrial context.

The Amendment has faced such challenges before. One of the first came around the turn of the twentieth century, in response to the attempts of post-Civil War landowners and industrialists to reinstate the practical realities of slavery in a more legally palatable form through the practice of peonage. No longer able to exploit slave labor as a formal institution, some employers pressed the law into service in the decades following emancipation, enacting statutes that purported to aim at such evils as debt default and fraud but had the effect of tying disempowered workers to forced terms of labor under threat of prosecution and imprisonment. The Supreme Court rose to this challenge, elevating substance over form and striking down these peonage schemes. ${ }^{3}$ In doing so, it carried forward into a new industrial context the Thirteenth Amendment's dual promise to emancipate the slave laborer within American industry and to emancipate American industry from slave labor.

The present era of globalization has brought with it the next logical step in this progression: the pressing into involuntary service of foreign

2. See infra Part I.B.

3. See infra Part I.A. 
laborers by U.S.-based multinational entities. Corporations based in the United States can now export the slave dependent elements of their business operations to foreign lands and then retrieve the fruits of those operations for domestic use and profit. With that step, we are once again seeing the reintroduction of slave labor into American industry. It has thus become necessary once again to translate the command of the Thirteenth Amendment for a new industrial context.

I choose the language of translation advisedly. ${ }^{4}$ As Professor Guyora Binder has observed, anyone seeking to articulate a coherent approach to modern interpretations of the Thirteenth Amendment must address difficult questions of history. ${ }^{5}$ The enactment of the Reconstruction Amendments undermined the precepts on which earlier approaches to constitutional interpretation had rested, throwing into question the proper interpretive approach to the Amendments themselves. "It was the Reconstruction Amendments' command to abolish one of American culture's defining customs," Professor Binder has observed, "that rendered them peculiarly uninterpretable." 6

In the case of the Fourteenth Amendment, this interpretive dilemma has already played out on the constitutional stage. The road from Plessy v. Ferguson 7 to Brown v. Board of Education ${ }^{8}$ marked a journey between two distinct visions of the relationship between tradition and constitutional analysis. In Plessy, the Court explicitly rested its rejection of the equal protection challenge to legally enforced segregation upon "the estab-

4. As Professor Lessig has noted, the term "translation" has been used to describe the interpretation of the Constitution under changing historical conditions. Lawrence Lessig, Understanding Changed Readings: Fidelity and Theory, 47 Stan. L. Rev. 395, 400 \& n.26 (1995); see also Paul Brest, The Misconceived Quest for the Original Understanding, 60 B.U. L. Rev. 204, 205 (1980) (using concept of translation to resist rigid applications of original intent doctrine).

5. Guyora Binder, The Slavery of Emancipation, 17 Cardozo L. Rev. 2063, 2063-64 (1996).

6. Id. at 2066. Professor Binder discusses the interpretive problem in the following terms:

For much of the nation's history, elites shared a conception of legal reasoning as a pragmatic process of adapting legal rules to evolving social custom. . . . Adherents to this school disagreed about what were, to them, the important issues: the content of evolving custom, the institutions best suited to discern it, and most importantly perhaps, the arena in which social custom evolved-the bazaar, the forum, or the laboratory. All agreed, however, that the evolving needs and values of society were knowable and legally authoritative.

...

... [Because] the institution of slavery was deeply and persistently entrenched in American society and culture, . . . the condemnation of slavery challenged the legitimacy of the very traditions and customs on which constitutional interpreters had always relied for guidance.

Id. at 2064-66.

7. 163 U.S. 537 (1896).

8. 347 U.S. 483 (1954). 
lished usages, customs and traditions of the people." ${ }^{9}$ Under that tradition, the Court explained, a separation of the races in public facilities could be defended as "reasonable, and ... enacted in good faith for the promotion of the public good." 10 Custom and usage were a sufficient response to a constitutional challenge under the dispensation to which the Plessy majority subscribed. One of the revolutionary changes wrought by Brown was a deliberate rejection of this interpretive method. "In approaching this problem [of segregation]," the Court wrote in Brown,

we cannot turn the clock back to 1868 when the Amendment was adopted, or even to 1896 when Plessy $v$. Ferguson was written. We must consider public education in the light of its full development and its present place in American life throughout the Nation. Only in this way can it be determined if segregation in public schools deprives these plaintiffs of the equal protection of the laws. ${ }^{11}$

Thus, in concluding that legally enforced segregation in educational facilities is "inherently unequal," 12 the Brown Court dramatically rejected custom and tradition, holding that the Fourteenth Amendment embodied substantive principles that do not automatically defer to established social norms. ${ }^{13}$ A similar observation may be made about the Fifteenth Amendment, which has occupied an interpretive landscape that has recapitulated that of the Fourteenth in most relevant respects. ${ }^{14}$

In the case of the Thirteenth Amendment, the interpretive problem has at once been more straightforward and more opaque. There has never been any question that the Amendment, in eradicating slavery and elevating emancipation to the status of a constitutional imperative, embodied a substantive rejection of one of America's most pervasive customs

\footnotetext{
9. 163 U.S. at 550 .

10. Id.

11. 347 U.S. at $492-93$.

12. Id. at 495 .

13. The Court added rhetorical reinforcement to this holding in Bolling v. Sharpe, the federal companion case to Brown, where it pronounced that "Classifications based solely upon race must be scrutinized with particular care, since they are contrary to our traditions and hence constitutionally suspect." 347 U.S. 497, 499 (1954) (citing Korematsu v. United States, 323 U.S. 214, 216 (1944); Hirabayashi v. United States, 320 U.S. 81, 100 (1943)). From an historical point of view, of course, classifications based solely upon race were very much a part of our traditions. The Court must be understood here to refer, not to the history of social norms in America, but to the constitutional tradition that, following Brown, can now supplant contrary custom or usage.

14. See City of Mobile v. Bolden, 446 U.S. 55, 61-62 (1980) (holding that Fifteenth Amendment only prohibits intentional discrimination), superseded by statute on other grounds, 42 U.S.C. $\$ 1973$ (1994); Washington v. Davis, 426 U.S. 229, 241 (1976) (same for Fourteenth Amendment); Rome v. United States, 446 U.S. 156, 207 n.1 (1980) ("[T]he nature of the enforcement powers conferred by the Fourteenth and Fifteenth Amendments has always been treated as coextensive.”). But see Rice v. Cayetano, 528 U.S. 495, 522 (2000) (holding that Fifteenth Amendment requirement of race neutrality in voting qualifications has additional force independent of Fourteenth Amendment "one person, one vote" requirement).
} 
and traditions. ${ }^{15}$ In that respect, the Thirteenth Amendment directly implemented a reshaping of the constitutional landscape that would only take hold in the other Reconstruction Amendments after the passage of ninety more years. But in a broader sense, the Thirteenth Amendment has yet to travel the road marked out by Plessy and Brown. Consider Robertson $v$. Baldwin, ${ }^{16}$ one of the early post-Reconstruction Thirteenth Amendment decisions, which the Court handed down in the Term following Plessy. In Robertson, a merchant seaman challenged a federal statute that authorized the imprisonment and forcible return of sailors who wished to leave the employ of their vessels. ${ }^{17}$ In rejecting this Thirteenth Amendment claim, the majority embraced the same interpretive method that it had recently deployed in its Fourteenth Amendment analysis in Plessy. Despite the radical rejection of tradition around the subject of slavery and labor that was inherent in the Thirteenth Amendment itself, the Robertson Court relied uncritically upon pre-Civil War common law authorities to carve out a substantive exception to the scope of the Amendment's command, concluding that "the amendment was not intended to introduce any novel doctrine with respect to certain descriptions of service which have always been treated as exceptional." 18 Indeed, Robertson includes a vigorous dissent by Justice Harlan, who staked out the same interpretive ground that he had occupied in his Plessy dissent a year earlier, rejecting the use to which the Robertson majority put custom and tradition as inappropriate following the enactment of the Thirteenth Amendment. ${ }^{19}$

15. See infra Part II.A. Judge Waring, dissenting in one of the desegregation cases that served as a precursor to Brown, noted that following the ratification of the Constitution, "slavery was perpetuated and eventually became a part of the life and culture of certain of the States of this Union although the rest of the world looked on with shame and abhorrence." Briggs v. Elliott, 98 F. Supp. 529, 541 (E.D.S.C. 1951) (Waring, J., dissenting).

16. 165 U.S. 275 (1897).

17. Id. at $275-76$.

18. Id. at 282. The Court found that "military and naval enlistments" were among these "exceptional" categories of service that fell outside the Amendment's substantive scope, along with "the right of parents and guardians to the custody of their minor children or wards." Id.

19. Justice Harlan wrote:

It is said that the statute in question is sanctioned by long usage among the nations of the earth, as well as by the above act of July 20, 1790. In considering the antiquity of regulations that restrain the personal freedom of seamen, the court refers to the laws of the ancient Rhodians, which are supposed to have antedated the Christian era. But those laws, whatever they may have been, were enacted at a time when no account was taken of man as man, when human life and human liberty were regarded as of little value, and when the powers of government were employed to gratify the ambition and the pleasures of despotic rulers rather than promote the welfare of the people.

Is the existing statute to be sustained because its essential provisions were embodied in the act of 1790 ? I think not, and for the reason, if there were no other, that the Thirteenth Amendment imposes restrictions upon the powers of 
To articulate a Thirteenth Amendment jurisprudence that is both internally coherent and in step with the interpretive method now firmly established for the Fourteenth and Fifteenth Amendments, one must avoid a myopic hindsight that views the Amendment as accomplishing nothing more than the constitutionalization of emancipation. This is especially so in seeking out sources to identify the core values that the Amendment embodies. Binder poses the problem in the following terms: "When the Constitution condemns society, where can we turn for aid in construing it? What aspects of American society authorize the Thirteenth Amendment and what aspects are amended by it? What was the essential feature of the slavery that the Thirteenth Amendment commands us to disestablish?" 20 The Court made an initial gesture toward answering these interpretive questions early in the twentieth century when it employed the Thirteenth Amendment to strike down the peonage and "antifraud" statutes mentioned above. ${ }^{21}$ But since then, despite the interpretive revolution in the other Reconstruction Amendments heralded by Brown and its progeny, the Court has developed no approach to two basic questions of interpretation: "What was the essential feature of the slavery that the Thirteenth Amendment commands us to disestablish"; and "[W]here can we turn for aid in construing it?" 22

This Article examines the most pressing contemporary application of these questions: the increasingly important role played by multinational corporate entities in forced labor practices around the globe. In doing so, it offers an approach to addressing the broader implications of the Thirteenth Amendment's interpretive challenge. My principal contention is that the Thirteenth Amendment forbids the deliberate incorporation of slave labor into American industry. More precisely, I contend that the knowing use of slave labor by U.S. based entities in their foreign operations constitutes the presence of "slavery" within the United States, as that term is used in the Thirteenth Amendment, and hence that this practice renders such U.S. entities subject to the prohibitory authority of American courts through a private civil action. The term "slavery" as it is used in the Amendment entails more than the physical presence of enslaved individuals. Slavery is a multilayered practice. It creates a distinctive form of interpersonal relationship. It depends upon the existence of

Congress that did not exist when that act was passed. The supreme law of the land now declares that involuntary servitude, except as a punishment for crime of which the party shall have been duly convicted, shall not exist anywhere within the United States.

Id. at 293-97 (Harlan, J., dissenting).

20. Binder, supra note 5 , at 2068 .

21. These issues are discussed at greater length in Part I. For a valuable discussion of the relationship between the interpretive approach to the Thirteenth Amendment and the Lochner Court's focus on freedom of contract as a limiting principle upon government regulation, see Risa L. Goluboff, The Thirteenth Amendment and the Lost Origins of Civil Rights, 50 Duke L.J. 1609, 1630-34 (2001).

22. Binder, supra note 5 , at 2068. 
interrelated, supporting institutions for its sustainability. And it arises not by happenstance, but in response to the urging of industries that benefit from its distinctive features and intentionally create a market for it. Those who drafted the Thirteenth Amendment understood all three of these aspects of slavery-the interpersonal, the institutional, and the industrial-to be vital elements of the practice that they sought to eradicate with the Amendment's enactment. In this Article, I hope to begin the process of translating that understanding into the language of the global economy and, in the process, to lay the foundation for a more modern and salient Thirteenth Amendment jurisprudence.

Part I examines the Court's translation of the Thirteenth Amendment to the changing industrial conditions of the late nineteenth and early twentieth centuries - the peonage cases-and provides an overview of the exploitation of forced labor in the emerging context of today's global economy. Part II employs an historical analysis of key elements of the American institutions of slavery and peonage to identify the principles underlying the Amendment's mandate that slavery "not exist" within the United States. ${ }^{23}$ Part II.A examines interjurisdictional slavery disputes-cases where slaves were carried to free jurisdictions-and recovers the conclusion, reached by nineteenth-century jurists, that slavery creates a robust social relation affecting the status of both master and slave. Part II.B traces the history of American efforts to prohibit illegal participation in the foreign slave trade and examines the Supreme Court's application of those prohibitions to certain supporting institutions-shipwrights and provisioners - that permitted illegal slave trading to flourish. Part II.C turns to the relationship between slavery and industrial forces, surveying the recognition by both jurists and scholars that slavery often arises because certain industries have intentionally created markets for forced labor. Part II ends by examining the proposed application of these principles to the foreign slave practices of contemporary American corporations. Part III then considers this foreign slavery doctrine in light of prior treatments of the extraterritorial application of American law.

\section{Translation And Industrial InNOvation}

The project of translation that I propose is not a new one for the Thirteenth Amendment. Despite its early embrace of a conservative interpretive approach in Robertson, the Supreme Court has since recognized the continuing need to apply the Amendment in new ways to the changing shape of American industry. In the peonage cases, the Court rejected a constrained, overly formalistic interpretation and took a step toward defining the principles lying at the Amendment's core. This Part begins

23. I take my project to be consonant with Professor Gerald Neuman's observation that, "To understand the course that American constitutionalism has taken since 1789, it is necessary to consider not only the rules that have been adopted at various historical periods, but also the normative visions underlying those rules and the choices faced by the decisionmakers.” Gerald L. Neuman, Whose Constitution?, 100 Yale L.J. 909, 913 (1991). 
with an examination of that early process of translation. It then goes on to describe the emerging problem of global labor exploitation and the need for a Thirteenth Amendment response.

\section{A. Early Translations: The Thirteenth Amendment and Domestic Industry}

The Thirteenth Amendment contains no state action requirement. ${ }^{24}$ It thus occupies a unique position in our Constitution. The rest of the Constitution sets forth a mandate for the operation of government and invests individuals with rights against the State. ${ }^{25}$ The Thirteenth Amendment is broader in scope. In addition to the restrictions that it places upon government, the Amendment imposes substantive limitations on the nature of allowable private social and economic relationships. ${ }^{26}$ These limitations were born of a particular context-the distinctively American system of chattel slavery-but extend beyond those origins to forbid "any other kind of slavery, now or hereafter." ${ }^{27}$ As the Court recently explained, the Amendment's prohibition against "involuntary servitude" encompasses all those "situations in which the victim is compelled to work by law" or is subjected to "compulsion through physical coercion." 28 And this broad prohibition is self-executing. ${ }^{29}$ While the Thirteenth Amendment has benefited from the assistance of implementing legislation, primarily in the form of criminal sanctions, ${ }^{30}$ such legisla-

24. See, e.g., United States v. Kozminski, 487 U.S. 931, 942 (1988) (“[T]he Thirteenth Amendment extends beyond state action .....").

25. See, e.g., DeShaney v. Winnebago County Dep't of Soc. Servs., 489 U.S. 189, 195-96 (1989) (holding Due Process Clause only invests individuals with negative rights against State and creates no affirmative constitutional duty).

26. Professor Binder has rendered this observation powerfully, writing: "The Thirteenth Amendment's countercustomary thrust is clear. Slavery was a historically present institution of society that had emerged as custom before it was recognized as law. To constitutionally abolish slavery was to disestablish and repudiate existing and enduring custom." Binder, supra note 5, at 2066.

27. The Slaughter-House Cases, 83 U.S. 36, 72 (1872). As the Court famously went on to explain, "If Mexican peonage or the Chinese coolie labor system shall develop slavery of the Mexican or Chinese race within our territory, this amendment may safely be trusted to make it void." Id.

28. Kozminski, 487 U.S. at 942.

29. See, e.g., The Civil Rights Cases, 109 U.S. 3, 20 (1883) ("By its own unaided force and effect [the Thirteenth Amendment] abolished slavery, and established universal freedom.").

30. See, e.g., 18 U.S.C. § 1582 (1994) (criminalizing participation of U.S. citizens in foreign slave trade); id. $\$ 1584$ (criminalizing involuntary servitude); id. $§ 1585$ (criminalizing sale of slaves in foreign slave trade).

I do not explore the question of what precise form remedies for private violations of the Thirteenth Amendment ought to take. It is clear that the Amendment is enforceable against private actors, and hence that some remedy is available even in the absence of a statutorily created cause of action. See The Civil Rights Cases, 109 U.S. at 20 (stating that Thirteenth Amendment is "self-executing without any ancillary legislation, so far as its terms are applicable to any existing state of circumstances"); Terry Props., Inc. v. Standard Oil Co., 799 F.2d 1523, 1534 (11th Cir. 1986) (suggesting that Thirteenth Amendment may impose liability directly against private actors). Only a handful of cases have 
tion has never been necessary to carry into effect the fundamental changes in social and economic relations that the Amendment itself brought about. ${ }^{31}$

The first such change, of course, was the eradication of the formal institution of chattel slavery in America. Following the enactment of the Amendment, human beings could no longer be bought and sold as property. But human ingenuity is perhaps most potent when aimed at selfenrichment, and in the wake of the Civil War, Southern industrial interests strove to devise employment schemes that would reproduce the reality of slave labor even in the absence of the formal institution. Thus arose the system of peonage.

Peonage was a system of forced labor that depended upon the indebtedness of a worker, rather than an actual property right in a slave, as the means of compelling work. A prospective employer would offer a laborer a "loan" or "advance" on his wages, typically as a condition of employment, and then use the newly created debt to compel the worker to remain on the job for as long as the employer wished. As the system of slavery looked to the law to enforce the property rights of the owner, so peonage pressed the law into service to enforce the property rights of the creditor, compelling service from the worker in payment of the debt. The juridical category was different- the property right in a human being, now forbidden, was replaced with the generally accepted right of a creditor to enforce a debt-but the result was largely the same: The coer-

considered the question, and they have differed as to whether a cause of action for monetary damages should be available in the absence of implementing legislation. Compare Channer v. Hall, 112 F.3d 214, 217 (5th Cir. 1997) (assuming availability of damages remedy directly under Thirteenth Amendment), with Turner v. Unification Church, 473 F. Supp. 367, 374 (D.R.I. 1978), aff'd mem., 602 F.2d 458 (1st Cir. 1979) (finding that court has power to award damages remedy but declining to do so in absence of implementing legislation). See also Samantha C. Halem, Slaves to Fashion: A Thirteenth Amendment Litigation Strategy to Abolish Sweatshops in the Garment Industry, 36 San Diego L. Rev. 397, 416-21 (1999) (using case of Thai garment workers subjected to forced labor in El Monte, California to explore remedies available under Thirteenth Amendment). A remedy for injunctive relief in the case of an ongoing violation of the Thirteenth Amendment is clearly available-and, in the case of foreign slavery abuses, perhaps more appropriate. Cf. Cargill, Inc. v. Monfort of Colo., Inc., 479 U.S. 104, 110-11 (1986) (explaining that standing requirements under antitrust laws are less stringent when private party seeks only injunctive relief).

31. Slavery receives similar treatment in international law. Slavery and forced labor are among the few human rights violations that rise to the level of a "peremptory norm"that is, constitute a remediable violation of international law without regard to the involvement of the state. See, e.g., Doe v. Unocal Corp., 963 F. Supp. 880, 891-92 (C.D. Cal. 1997) (holding that slavery is one of a "handful of crimes" actionable against individuals under international law principles and need not be the result of state action); International Labour Office, Stopping Forced Labour 12-13 (2001), available at http:// www.ilo.org/declaration [hereinafter Stopping Forced Labour] ("With coercion at the heart of forced labour, the principle of eliminating it applies irrespective of whether the perpetrators are acting officially, as agents of the State, or unofficially as private individuals."). 
cive power of the State was used to compel labor from poor (and usually black) workers, on threat of imprisonment.

Legally sanctioned peonage arrangements blossomed in the South following the Civil War and continued into the twentieth century. According to Professor Jacqueline Jones, "perhaps as many as one-third of all [sharecropping farmers] in Alabama, Mississippi, and Georgia were being held against their will in 1900." 32 Not surprisingly, employers used peonage arrangements primarily in industries that involved hazardous working conditions and very low pay. ${ }^{33}$ While black workers were not the exclusive victims of peonage arrangements in America, they suffered under its yoke in vastly disproportionate numbers. ${ }^{34}$ Along with Jim Crow laws that segregated transportation and public facilities, these laws helped to restrict the movement of freed black workers and thereby keep them in a state of poverty and vulnerability. ${ }^{35}$

As a formal matter, peonage rested on seemingly unobjectionable legal foundations. It was frequently a "voluntary" arrangement; that is, workers with little or no alternative would "voluntarily" assume the obligation that rendered them subject to the threat of debtor's prison. More importantly, peonage eschewed those features of slavery around which some of the most pointed criticism had centered in nineteenth century legal discourse. It did not recognize a property right in a human being (a peon could not be sold in the manner of a slave) $; 36$ and the condition of peonage did not work "corruption of blood" and travel to the children of the worker. ${ }^{37}$ Peonage, in short, was not chattel slavery. Yet the practice

32. Jacqueline Jones, The Dispossessed 107 (1992).

33. See, e.g., id. at 128-29 (describing peonage in phosphate industry in turn of the century Florida, which entailed difficult and dangerous seasonal work); id. at 152-53 (same for turpentine extraction).

34. See id. at 154 ("The peonage files of the U.S. Justice Department bulge with the records of cases reported to the attorney general, beginning in 1901, and reveal the pervasive use of non-free black labor in the South's rural industries.").

35. Id. at 107 .

36. A peon's debt could be assigned or "sold," however. See, e.g., Goluboff, supra note 21, at 1661 (describing sale and assignment of peonage debts as fairly common practice in turn of the century South). While such a transfer would not entail the type of radical dislocation that was notorious in the sale of chattel slaves, it further embodied the commodification of the individual that was inherent in peonage arrangements: "[T]he sale of debt arguably may have enhanced worker mobility . . . . The fact that debts were sold, that people could remain in debt for long periods of time, and that movement between jobs and employers was difficult, albeit perhaps not impossible, were considered indications of a failure of free labor." Id.

37. See, for example, the description provided by a federal district court in Alabama at the turn of the century, in an opinion striking down local peonage provisions as violative of the Thirteenth Amendment:

The peon was not a slave. He was a freeman, with political as well as civil rights. He entered into the relation from choice, for a definite period, as the result of mutual contract. The relation was not confined to any race. The child of a peon did not become a peon, and the father could not contract away the services of his minor child, except in rare cases. The peon, male or female, agreed with the 
unquestionably reproduced many of the immediate practical realities of slavery-a vast underclass of laborers, held to their jobs by force of law and threat of imprisonment, with few if any opportunities for escape. ${ }^{38}$

The Reconstruction Congress, not insensible to this reintroduction of slave labor to American industry, outlawed peonage and passed criminal statutes under the authority of the Thirteenth Amendment to enforce that proscription. ${ }^{39}$ Enforcement of the statutes was sporadic at first but became more vigorous by the turn of the century. ${ }^{40}$ When prosecutions began to reach the Supreme Court, they presented the Court with a challenge. Would the Court adopt a strictly formal approach to the Thirteenth Amendment and its enforcing legislation and refuse to extend its ambit to those "voluntary" peonage arrangements to which laborers subjected themselves? Or would it give the Amendment an expansive interpretation that would reach all instances of involuntary labor, whatever form they took? Given the narrow interpretation of the Fourteenth Amendment and its enforcement power adopted by the Court twenty years earlier in the Civil Rights Cases, ${ }^{41}$ an expansive interpretation was not a foregone conclusion. But in Clyatt v. United States, ${ }^{42}$ the Court decisively chose that course. Rejecting arguments that would privilege form over substance, the Court reiterated in Clyatt that the Thirteenth Amendment eradicated slavery and involuntary servitude of every manifestation:

Peonage is sometimes classified as voluntary or involuntary, but this implies simply a difference in the mode of origin, but none in the character of the servitude. The one exists where the debtor voluntarily contracts to enter the service of his creditor. The other is forced upon the debtor by some provision of law. But peonage, however created, is compulsory service, involuntary servitude. ${ }^{43}$

master upon the nature of the service, the length of its duration, and compensation. The peon then became bound to the master "for an indebtedness founded upon an advancement in consideration of service."

Peonage Cases, 123 F. 671, 673-74 (M.D. Ala. 1903). Note, however, that the master in a peonage relationship could sell the debt of the peon (and with it the obligation to work), with or without the consent of the worker. Id.

38. For a useful discussion of the rise of peonage and other similar arrangements during and after Reconstruction, see Lea S. VanderVelde, The Labor Vision of the Thirteenth Amendment, 138 U. Pa. L. Rev. 437, 485-95 (1989).

39. See 42 U.S.C. $\$ 1994$ (1994) (abolishing peonage and nullifying any act or law that establishes or maintains such a system); see also, e.g., Peonage Act of 1867, 14 Stat. 546 , ch. 187, § 1 (1867), codified at 18 U.S.C. $\$ 1581$ (2000) (prohibiting peonage in Reconstruction era).

40. Jones, supra note 32, at 153-54; Goluboff, supra note 21, at 1637-47. For an important and detailed examination of subsequent federal enforcement efforts during the first half of the twentieth century, see id. at 1637-68.

41. See The Civil Rights Cases, 109 U.S. 3, 11 (1883).

42. 197 U.S. 207 (1905).

43. Id. at 215 . 
Not to be deterred, some Southern states responded to Clyatt by repackaging their peonage schemes as "antifraud" proscriptions. ${ }^{44}$ These provisions operated to enforce the same system of forced indebtedness through salary advances that had existed under traditional peonage arrangements. But here, the mode of enforcement was an evidentiary presumption. The presumption provided that any employee who accepted an advance on his salary and then chose to leave before his term of labor was up must have intended to "defraud" his employer. Under this modified peonage system, prosecutions for fraud replaced prosecutions for debtor default as the means of enforcing the forced labor arrangement. When these statutes were challenged under the Thirteenth Amendment, the Court once again declined to elevate form over substance, holding in Bailey $v$. Alabama that " $[\mathrm{w}]$ hat the state may not do directly it may not do indirectly" through an evidentiary presumption. ${ }^{45}$ In a series of cases beginning with Bailey, the Court struck down these "fraud" statutes as yet another device for reintroducing involuntary servitude into American industry. ${ }^{46}$

Given the much noted statement of the Court forty years earlier in the Slaughter-House Cases that the Thirteenth Amendment was not limited in its application to chattel slavery but would prohibit a Mexican peonage or Chinese coolie system from evolving into a system of involuntary servitude, ${ }^{47}$ it could be argued that the results in Clyatt and Bailey were prefigured. Nonetheless, their significance in the doctrinal evolution of the Thirteenth Amendment should not be missed. In finding that the Thirteenth Amendment and its implementing legislation operated to prohibit peonage-however named and through whatever device accomplished-the Court translated the mandate of the Thirteenth Amend-

44. See Pollock v. Williams, 322 U.S. 4, 7-13 (1944) (describing history of peonage statutes, revisions, and court challenges in Southern states).

45. 219 U.S. 219, 244 (1911).

46. See id. ("If [the State] cannot punish the servant as a criminal for the mere failure or refusal to serve without paying his debt, it is not permitted to accomplish the same result by creating a statutory presumption which upon proof of no other fact exposes him to conviction and punishment."); id. at 242 ("Congress was not concerned [in antipeonage statute] with mere names or manner of description, or with a particular place or section of the country. It was concerned with a fact, wherever it might exist; with a condition, however named and wherever it might be established, maintained or enforced."); infra note 206 (describing peonage cases).

As one might expect, however, the Supreme Court's rulings did not immediately eradicate the practice of peonage:

Despite the formal end to debt peonage in 1911 (as a result of the Supreme

Court's Alonzo Bailey decision), black and white croppers throughout the South

continued to believe that they risked bodily harm to themselves if they left a place

over the objections of its owner; and they were right.

Jones, supra note 32 , at 114 .

47. The Slaughter-House Cases, 83 U.S. 36, 72 (1872); see also Akhil Reed Amar \& Daniel Widawsky, Child Abuse as Slavery: A Thirteenth Amendment Response to DeShaney, 105 Harv. L. Rev. 1359, 1368 (1992) (discussing expansive implications of the SlaughterHouse Cases). 
ment into a new context for American industry. ${ }^{48}$ It adopted an expansive mode of practical reasoning and found the Amendment applicable to whatever manifestations of slavery or involuntary servitude should enjoy a presence within the reach of U.S. jurisdiction. ${ }^{49}$ And it definitively rejected the assertion that workers could bear complicity for their own enslavement by "voluntarily" entering into arrangements of power and dominance. ${ }^{50}$

\section{B. Foreign Labor Practices and the Globalization of American Industry}

The Court's disapproval of domestic peonage laws did not definitively eradicate all domestic forced labor. Such exploitation does still occur within the United States, as recent investigations of the garment industry and the use of imported domestic servants have demonstrated. ${ }^{51}$

48. Cf. Goluboff, supra note 21, at 1647-48 ("During World War II and the years that followed, the [Justice Department] Civil Rights Section's uses of the Thirteenth Amendment reflected a broadening of the Amendment's meaning from a Lochner-era emphasis on debt to include servitude that resulted from other types of legal, economic, and social coercion.").

49. See Bailey, 219 U.S. at 242 (stating that, in passing antipeonage legislation, Congress "was concerned with a fact, wherever it might exist; with a condition, however named and wherever it might be established, maintained or enforced").

50. Professor Goluboff argues that Clyatt and the other early peonage cases did not go as far as they might have in embracing a broad principle of free labor under the Thirteenth Amendment. Goluboff, supra note 21, at 1637-39. "Although the Court still expressed free labor aspirations" in the early peonage cases, she explains, "it defined peonage narrowly and reinforced the notion that the Thirteenth Amendment was a rule that abolished a small and diminishing category of unfree servitudes without touching either the core racial or class inequalities of American society.” Id. at 1639. Goluboff convincingly asserts that the full promise of the peonage cases was only realized in Pollock v. Williams, 322 U.S. 4 (1944), the Court's last word on the issue, where it finally employed language suggesting the possibility of broader, liberatory implications for American labor. Goluboff, supra note 21, at 1674-75. The Pollock Court wrote:

When the master can compel and the laborer cannot escape the obligation to go on, there is no power below to redress and no incentive above to relieve a harsh overlordship or unwholesome conditions of work. Resulting depression of working conditions and living standards affects not only the laborer under the system, but every other with whom his labor comes in competition.

322 U.S. at 18.

Professor Goluboff's insights here (as throughout her article) are valuable, and I take them to be fully consistent with my own account of the evolution of the peonage doctrine. For Goluboff's purposes, the narrowing of focus in the early peonage cases to a particular mode of labor exploitation represents a doctrinal step backward. For my purposes, the Court's vigorous enforcement of free labor principles within that narrow focus, and particularly its refusal to permit actual instances of forced labor to cloak themselves effectively in unobjectionable legal categories, represents an important doctrinal innovation. And more to the point, Goluboff and I find in Pollock the same flowering of certain principles of liberation embedded in the Thirteenth Amendment, as my subsequent discussion of the case will make clear. See infra text accompanying notes 202-219.

51. See, e.g., Goluboff, supra note 21, at 1662-68 (describing exploitation of domestic servants through peonage arrangements in early twentieth century); Halem, supra note 30 , 
But such situations are exceptional; in its most basic application, the Thirteenth Amendment has been a success. The most pervasive problems of slavery and involuntary servitude in America now involve the exploitation by U.S. corporations of workers in foreign countries. In some places, these forced labor practices reflect cultural struggles-often exacerbated by colonialism-that have existed since long before western investors looked abroad for cheap labor; in others, forced labor has arisen as a direct response to the demands of multinational corporations. What follows is a description of several instances of forced labor in foreign jurisdictions, exhibiting varying degrees of American corporate involvement. ${ }^{52}$

1. The Resource Extraction Industry in Burma. - The exploitation of forced labor in Burma ${ }^{53}$ is perhaps the most egregious and heavily documented instance of labor abuse in the international community today. Following a 1962 coup d'état, Burma came under the rule of a military government. That regime has committed brutal human rights violations against its people in suppressing democratic activities and repressing ethnic minorities. The violations have included summary execution, rape and sexual abuse, and regular denial of civil liberties. They have been so extreme that Burma has been targeted for singular censure by the international community. ${ }^{54}$ This censure has included the unprecedented es-

at 400-09 (same for U.S. garment industry); A. Yasmine Rassam, Contemporary Forms of Slavery and the Evolution of the Prohibition of Slavery and the Slave Trade Under Customary International Law, 39 Va. J. Int'l L. 303, 328 n.110 (1999) (discussing abuse of imported domestic workers as housebound slaves).

52. My principal focus in this overview concerns the exploitation of foreign slave labor by domestic industries that produce otherwise legal products, such as energy resources or manufactured goods. I do not address the widespread practice of sexual slavery, in which human beings (usually women or minors) are brutally compelled to submit to prostitution and rape for the enrichment of others. This omission is solely a consequence of the fact that my thesis has limited practical application to forced labor in industries that are themselves illegal in the United States. But as international organizations and scholars alike have recognized, the practice of sexual slavery is both severe and pervasive, deserving close attention. See, e.g., Kevin Bales, Disposable People 34-79 (1999) (detailing system of sexual slavery in Thailand); Stopping Forced Labour, supra note 31, at 47-58 (reporting on trafficking of women and minors for use as sexual slaves); Etsuro Totsuka, Commentary on a Victory for "Comfort Women": Japan's Judicial Recognition of Military Sexual Slavery, 8 Pac. Rim L. \& Pol'y J. 47, 47-48 (1999) (discussing sexual slavery practices undertaken by Japanese military); Vanessa B.M. Vergara, Comment, Abusive Mail-Order Bride Marriage and the Thirteenth Amendment, 94 Nw. U. L. Rev. 1547, 1547-68 (2000) (discussing abuse of women imported as brides from Asian and eastern-bloc countries).

53. The country of Burma is also known as Myanmar. The U.S. government continues to use the name "Burma" in its foreign diplomacy. Doe v. Unocal Corp., $110 \mathrm{~F}$. Supp. 2d 1294, 1296 n.1 (C.D. Cal. 2000).

54. Myriad international organizations have identified the Burmese regime as one of the worst human rights offenders in the world today. Indeed, the International Labour Office (a division of the United Nations) credits the sheer magnitude of labor abuses in Burma with the recent elevated international attention to such practices throughout the world: "Worldwide attention to forced labour has increased in recent years through the international appeals to one country in particular (Myanmar) to rectify that persistent 
tablishment of a Commission of Inquiry by the U.N.'s International Labour Office (ILO), which has made broad recommendations for improving conditions in Burma..$^{55}$

Forced labor practices have been a prominent component of the Burmese military's abuses. ${ }^{56}$ In recent years, many of those practices have centered around the construction of two natural gas pipelines, the Yadana and the Yetagun, designed to transport natural gas from eponymous deposits off the coast of Burma for sale in neighboring Thailand. ${ }^{57}$ The pipelines were constructed and are being operated by a joint venture, the principal participants of which are two western energy companies: Unocal, a California corporation, and Total, a French entity. Unocal and Total have employed the assistance of the Burmese military since they began work on the project in the early 1990s. ${ }^{58}$ Throughout the life of the project, the military has followed a consistent practice of enslaving its own people to support the profitable extraction and transportation of natural gas in partnership with Unocal and Total. ${ }^{59}$

Forced labor in the Yadana and Yetagun projects has taken several distinct forms, which may roughly be divided into three categories. In each case, local villagers, most of them members of the Karen ethnic mi-

problem." Stopping Forced Labour, supra note 31, Executive Summary, at vii. See also Situation of Human Rights in Myanmar: Report of the Comm'n on Human Rights, U.N. ESCOR, 56th Sess., Supp. No. 3, at 132-33, U.N. Doc. E/CN.4/2000/167 (2000) (deploring human rights violations in Myanmar).

Some states and municipalities in the U.S. have also attempted to respond to the abuses in Burma through the enactment of local policies against contracting with companies that do work in the country. One such law was the subject of the recent Supreme Court decision placing limits on the ability of nonfederal entities to adopt policies that may impact foreign relations. Crosby v. Nat'l Foreign Trade Council, 530 U.S. 363, 373-74 (2000) (striking down Massachusetts law that restricted ability of state entities to contract with companies doing business in Burma).

55. International Labour Office, Measures Recommended by the Governing Body Under Article 33 of the Constitution-Implementation of Recommendations Contained in the Report of the Commission of Inquiry Entitled Forced Labour in Myanmar (Burma), International Labour Conference, 88th Sess., Geneva, Provisional Record No. 4, at 4/2 (2000); Stopping Forced Labour, supra note 31, at 44-46.

56. See Bales, supra note 52, at 247 ("The current military dictatorship in Burma, which enslaves its own citizens, has faced censure in the media and in the United Nations and the European Union after reports from [NGOs].").

57. A thorough account of human rights abuses in Burma connected with the Yadana and Yetagun projects may be found in a report issued by EarthRights International, a nongovernmental human rights organization. EarthRights Int'l, Total Denial Continues, passim (2000) [hereinafter Total Denial Continues]. The Yadana and Yetagun projects have also given rise to a number of lawsuits in state and federal court in California, seeking damages against the corporations for their role in perpetuating human rights abuses against the plaintiff indigenes. Those cases include accounts of the factual allegations against the companies. See, e.g., Doe v. Unocal Corp., 963 F. Supp. 880, 883-85 (C.D. Cal. 1997).

58. Unocal, 110 F. Supp. 2d at 1298.

59. Total Denial Continues, supra note 57, at 25-96. The district court in Unocal recounts allegations to the same effect. Unocal, 110 F. Supp. 2d at 1298. 
nority, have been forcibly conscripted into service under threat of violence. First, villagers have been forced to clear the great swaths of land over which the pipelines were laid, often having to cut and clear kilometers-wide corridors through jungle growth. ${ }^{60}$ Second, local populations have been forced to construct support structures for the project on an ongoing basis-for example, landing pads for the helicopters that provide transport for foreigners traveling in the region, or barracks for the military personnel guarding the project. ${ }^{61}$ And third, locals are regularly forced to serve as porters for the military personnel working on the project, often carrying crippling loads without rest. ${ }^{62}$ These forms of forced labor have been vital to the construction and operation of the pipelines.

The extent to which Unocal and Total have participated in these forced labor practices remains contested. ${ }^{63}$ There is no question that the companies have worked closely with the military regime throughout the project-coordinating the clear cutting and the construction of support facilities, for example, and using soldiers to provide on-site security. ${ }^{64}$ There is substantial evidence demonstrating that the companies knew from an early stage that the military was enslaving the local populations to work on the pipelines and chose to continue with the project nonetheless. ${ }^{65}$ Company executives apparently acknowledge that the relationship between the companies and the military has been an agency or employment relationship, as in the following account by U.S. Embassy personnel of statements made by a senior Unocal executive, Joel Robinson: "On the general issue of the close working relationship between Total/Unocal and the Burmese military, Robinson had no apologies. He stated forthrightly that the companies have hired the Burmese to provide security for the project and pay for this through [a subsidiary of the joint venture]." 66 Unocal and Total deny any complicity in slave labor practices in Burma, though there are reports of continuing abuses on the project. ${ }^{67}$

Other U.S. corporations have also participated in the Yadana and Yetagun pipelines, although their connection to the exploitation of slaves on the project appears to be more tenuous. Most notable among these is

60. Total Denial Continues, supra note 57, at 87-96.

61. Id. at $25-30,82-87$.

62. Id. at 53-61.

63. In part, outside organizations have been hampered in their ability to develop evidence concerning human rights violations in Burma because of the inaccessibility of the country to outsiders under the current military regime. See Bales, supra note 52, at 265-66.

64. See Unocal, 110 F. Supp. 2d at 1297-99.

65. Total Denial Continues, supra note 57, at 62-99.

66. Id. at 62 (quoting U.S. Dep't of State Unclassified Cable from U.S. Embassy in Rangoon, Cable No. 002067, at If 28 (1995)).

67. Seth Mydans, Accusations of Forced Labor, N.Y. Times, June 13, 2001, at A10 (noting reports by Human Rights Watch and Amnesty International of continuing abuses in Burma); Human Rights Watch, World Report 2001: Burma Still Using Forced Labor (June 12, 2001), at http://www.hrw.org/press/2001/06/burma0612.htm (on file with the Columbia Law Review). 
Halliburton Co., a major energy corporation formerly headed by nowVice President Richard Cheney. In the mid 1990s, Halliburton helped lay the offshore portion of the pipeline that extends to the Yadana gas fields. ${ }^{68}$ The company has declined to state whether it was aware of the ongoing forced labor practices when it aided in constructing the pipeline ${ }^{69}$ Responding to inquiries on the subject in 1997, Cheney replied, "The problem is that the good Lord didn't see fit to always put oil and gas resources where there are democratic governments." 70 Abuses in the resource extraction industry have been documented in other regions of the world as well. In Brazil, for example, the domestic steel industry depends upon forced labor to obtain inexpensive charcoal for use in its production process. ${ }^{71}$

2. Manufacturing Industries. - American companies regularly export portions of their manufacturing and assembly work to foreign markets in order to take advantage of their inexpensive and unregulated labor forces. This is particularly true in the garment industry, in which the assembly and manufacturing work for many high profile American labels is performed abroad. In increasing numbers, reports of forced labor are coming to light in such foreign manufacturing facilities. As Professor Kevin Bales explains, "international business now seeks to buy labor at the lowest cost, often through subcontractors, [and] some of these contractors achieve the lowest cost by using slave labor."72

In some countries, forced labor practices in manufacturing benefit from the practice of "bonded labor," a traditional form of peonage or indentured servitude in which a laborer is compelled to work in order to pay off a debt. In such countries, the tradition of bonded labor may lure foreign manufacturers with the promise of a cheap, disposable workforce. One much noted example may be found in Pakistan, where bonded labor arrangements have traditionally been used to compel work from children. Though now officially illegal, these arrangements have a long and

68. EarthRights Int'l, Halliburton's Destructive Engagement 4-5 (2000).

69. E.g., Peter Waldman, A Pipeline Project in Myanmar Puts Cheney in Spotlight, Wall St. J., Oct. 27, 2000, at A1 ("At Halliburton, a spokeswoman says the company used no forced labor on the pipeline. But she refuses to comment on the company's decision to work in Myanmar or whether Halliburton was aware of human-rights or security concerns in Myanmar during Mr. Cheney's tenure."); cf. Stopping Forced Labour, supra note 31, at 45 (describing forced labor abuses in Myanmar and explaining that "Sometimes, this forced labour had been imposed for the profit of private individuals").

70. Waldman, supra note 69; see also Agis Salpukas, Foreign Energy, Domestic Politics: Burmese Project Tests Unocal Resolve, N.Y. Times, May 22, 1997, at D1 (describing Unocal's dependence upon foreign investment and public and political pressure regarding its projects in Burma).

71. See Bales, supra note 52, at 23 (describing use of slave labor in Brazilian steel industry); Stopping Forced Labour, supra note 31, at 25 (describing variety of forced labor practices in Brazil).

72. Bales, supra note 52, at 236.

$\mathbf{R}$

$\mathbf{R}$ 
robust history. ${ }^{73}$ Nike, Gap, and other American corporations have contracted assembly work to Pakistani manufacturers that employ such involuntary child workers, allegedly with the knowledge that slave labor would be used to assemble their products more cheaply. ${ }^{74}$

Forced labor also occurs in sweatshops specially constructed to serve American corporations. In the late 1990s, allegations that such clothing producers as Nike and Gap used forced labor in Asian sweatshops to manufacture their clothes received considerable attention in the media. ${ }^{75}$ More recently, garment workers in Saipan, an island in the Commonwealth of the Northern Mariana Islands, ${ }^{76}$ have filed a series of lawsuits in federal district court in California charging that conditions of peonage, indentured servitude, and forced labor have predominated in the sweatshops where they work. ${ }^{77}$ The original suit named twenty-six major American clothing manufacturers as defendants, all of whom allegedly conspired to exploit the involuntary labor of foreign workers imported to work in the Saipan facilities. ${ }^{78}$ As of mid-2001, nineteen of the defend-

73. See id. at 149-94 (describing problem of bonded labor in Pakistan); Stopping Forced Labour, supra note 31, at 40-42 (same).

74. CorpWatch, "Action Alert," Blood, Sweat \& Shears, at http://www.corpwatch. $\mathrm{org} / \mathrm{trac} /$ feature/sweatshops/countries/pakistan.html (last visited Jan. 24, 2002) (on file with the Columbia Law Review) (describing use of forced child labor in production of soccer balls for Nike and other corporations and concluding that "up to $20 \%$ of the balls brought to the U.S. continue to be stitched by children under the age of 14"); see also Bales, supra note 52, at 236-37 (describing use of bonded and slave labor by Nike, Gap, and other companies in Pakistan, India, Thailand, and Brazil).

75. See Bales, supra note 52, at 236; Russell Mokhiber \& Robert Weissman, Corporate Predators: The Hunt for Mega-Profits and the Attack on Democracy 164-66 (1999).

76. The Northern Mariana Islands are a protectorate of the United States, so there is no question that the Thirteenth Amendment and its implementing statutes apply to the workers' claims. See Reynolds v. United States, 98 U.S. 145, 154 (1878) (applying Sixth Amendment rights to criminal prosecution in Territory of Utah); Neuman, supra note 23, at 955-57 (discussing Reynolds and applicability of Constitution to U.S. territories). Given their geographical, cultural, and economic distance from the political community of the United States, however, the exploitation of forced labor on the Islands speaks to the greater potential for labor exploitation in Asia and the South Pacific.

77. William Carlsen, Sweatshop Conditions Alleged on U.S. Island: Retailers Sued for Selling "Made in U.S.A." Garments, S.F. Chron., Jan. 14, 1999, at A1; Steven Greenhouse, Suit Says 18 Companies Conspired to Violate Sweatshop Workers' Civil Rights, N.Y. Times, Jan. 14, 1999, at A9.

From the time the lawsuit was filed until June 2000, the author was a litigator at a law firm representing some of the original defendants. The author was never involved in any of the cases. The brief summary that follows relies entirely upon publicly available information.

78. Sweatshop Watch, Summary of the Saipan Sweatshop Litigation (Oct. 10, 2000), at http://www.sweatshopwatch.org/swatch/marianas/summary10_00.html (listing manufacturers named in suit) (on file with the Columbia Law Review); see also Douglas S. Morrin, People Before Profits: Pursuing Corporate Accountability for Labor Rights Violations Abroad Through the Alien Tort Claims Act, 20 B.C. Third World L.J. 427, 441-45 (2000) (reviewing Mokhiber \& Weissman, supra note 75) (describing allegations in Saipan cases); Kevin Tessier, Project, The New Slave Trade: The International Crisis of Immigrant Smuggling, 3 Ind. J. Global Legal Stud. 261, 261-64 (1995) (describing

$\mathbf{R}$

$\mathbf{R}$

$\mathbf{R}$

$\mathbf{R}$ 
ants had settled, but the lawsuit continued against such manufacturers as Levi Strauss \& Co., Gap, and Abercrombie and Fitch. ${ }^{79}$ Recent news reports suggest that similar conditions of involuntary servitude may exist in garment sweatshops in Samoa, another American protectorate in the South Pacific. ${ }^{80}$

3. Agricultural Industries. - Some of the most extensive exploitation of slave labor occurs in agricultural industries. Poor workers around the world are regularly compelled to work in food production. In many cases, such forced labor takes the form of debt bondage. The ILO reports that debt bondage in agriculture remains a problem in many countries of South and Central America, including Guatemala, Mexico, Peru, Haiti, the Dominican Republic, and Brazil,${ }^{81}$ and also in India, Pakistan, and Nepal. ${ }^{82}$ The report explains:

Serious problems exist in remote areas; for example, tropical forests have been opened up for agricultural, mineral or forestry development. The persons susceptible to abuse may be indigenous and tribal peoples. ... Thus the problems of coercion are often connected with seasonal labour migration, both within and across national frontiers. The migration may be to jobs in agriculture, forestry, processing of food products or materials, or domestic work but all risk ending up in debt bondage. ${ }^{83}$

Forced agricultural labor may even result in systems of outright chattel slavery, though such cases are rare. In Mauritania, a country in northwest Africa, a de facto state of slavery still holds much of the African ethnic minority in its grip, despite the official abolition of slavery as an institution in $1980 .{ }^{84}$ Slaves continue to support every sector of the

smuggling of immigrants from Asian countries, particularly China, to become exploited workers in U.S.); Carlsen, supra note 77 (describing allegations of "slavery-like conditions" including "guarded barb-wire compounds").

79. Sweatshop Watch, supra note 78; Sweatshop Watch, Saipan Sweatshop Litigation: An Update (Apr. 13, 2001), at http://www.sweatshopwatch.org/marianas/saipanupdate may01.html (listing defendants who had settled to date) (on file with the Columbia Law Review).

80. E.g., Janet Moore, From Sweatshop to Here: Two Vietnamese Women Have Landed at a Minneapolis Hotel After Fleeing a Garment Factory on American Samoa, Star Trib. (Minneapolis), June 1, 2001, at D1 (reporting that owner of Samoan factory manufacturing clothes for J.C. Penney, Kohl's, and Target has been charged by FBI with subjecting workers to conditions of forced labor).

81. Stopping Forced Labour, supra note 31, at 21-28.

82. Id. at 32-43; Bales, supra note 52, at 8-10.

83. Stopping Forced Labour, supra note 31, at 21. One much noted situation persists in the Dominican Republic, where thousands of Haitian laborers regularly migrate to work in the sugarcane fields and are subjected to conditions that many argue amount to forced labor or slavery. Id. at 24-25; Bales, supra note 52, at 236. See generally Michelle E. Gorden, Comment, Haitian Forced Labor in the Dominican Republic, 15 Comp. Lab. L.J. 206, 212-23 (1994) (discussing Haitian labor problems in the Dominican Republic).

84. Bales, supra note 52 , at $80-81$.

\section{$\mathbf{R}$}

$\mathbf{R}$ 
Mauritanian economy, including the agricultural, and are still bought and sold as property. ${ }^{85}$

While this exploitation of forced labor in agriculture often occurs on a local scale, the fruits of slave labor may also be incorporated directly into the production process for goods manufactured in the United States. One recent example that has received worldwide attention is the farming of cocoa beans in West Africa, particularly in Ivory Coast. West African nations produce over forty percent of the world's cocoa. ${ }^{86}$ Child laborers, many of them imported from neighboring Mali and Burkina Faso, are sometimes forced to work as slaves on cocoa farms and plantations. ${ }^{87}$ The cocoa beans that they produce are imported to the United States, processed at plants in Wisconsin, Minnesota, and California, and turned into chocolate products sold throughout the domestic market. ${ }^{88}$

\section{A New Industrial Context}

The ubiquitous operation of multinational corporations in global labor markets represents another, dramatically new context for American industry. In rapidly increasing numbers, U.S.-based corporations are becoming involved in foreign slave practices. In some instances, U.S. entities deliberately export components of their operations to overseas markets in order to take advantage of the radically different labor conditions found in less developed nations. In others, U.S. industries merely purchase products on the global market and may be uninvolved, and unconcerned, with the labor practices that produce them. How are these situations to be analyzed? When slavery and involuntary servitude are employed on American soil, the ultimate disposition of the goods that they produce is largely irrelevant. The presence of an involuntary laborer itself offends the Thirteenth Amendment. Ironically, this uncompromising approach to domestic slavery has produced an impoverished Thirteenth Amendment vocabulary. We do not yet have the doctrinal tools that are required to analyze the more sanitized incorporation of slavery into American industry that has appeared in the activities of U.S. energy corporations in Burma, or the activities of U.S. fashion producers and manufacturers in Pakistan and Southeast Asia.

85. Id. at 81 ("In Mauritania today there is no slavery, and yet everywhere you look, on every street corner and shop, in every field and pasture, you see slaves. . . Mauritania's economy rests squarely on their backs."); Rassam, supra note 51, 321-24 \& 322 nn.72, 75 (describing slave practices within Mauritania and Sudan).

86. Much of America's Sweets Made Possible Through Slave Labor on Ivory Coast, Knight Ridder/Trib. Bus. News (Washington), June 25, 2001, at 1 [hereinafter America's Sweets].

87. Stopping Forced Labour, supra note 31, at 21-22; cf. Adam Jones, Chocolate Boycott Warning, The Financial Times (London), May 5, 2001, at 2 (quoting British Foreign Office minister, who opposes boycott of chocolate, saying "It is clear that forced labour is used in some sectors of the cocoa industry, though there is no evidence it is widespread.").

88. America's Sweets, supra note 86, at 2. 
And it is not just the practices of American industry that have changed. Slavery has evolved as well. While chattel slavery arrangements like those that once existed in the United States may still be found in isolated cases, as in Mauritania, they are the exception. The present state of American involvement in foreign slave labor practices is quite different. With only rare exceptions, slavery is no longer an openly defended institution that supporters make use of unabashedly. Like the vectors by which it is incorporated into American industry, the slave relationship itself is often obscured. Professor Bales writes:

In the past, slavery entailed one person legally owning another person, but modern slavery is different. Today slavery is illegal everywhere, and there is no more legal ownership of human beings. When people buy slaves today they don't ask for a receipt or ownership papers, but they do gain control-and they use violence to maintain this control. Slaveholders have all of the benefits of ownership without the legalities. Indeed, for the slaveholders, not having legal ownership is an improvement because they get total control without any responsibility for what they own. ${ }^{89}$

Once again, our rejection of such innovations in slavery when they occur domestically is well established. The evolution in the dynamics of slavery that Bales describes has already played out in miniature on the domestic stage with the rise of peonage laws following the Civil War. As described earlier, peonage arrangements enabled employers to use the coercive processes of the law to exercise control over indebted workers. It permitted them to do so, moreover, without incurring any of the duties and obligations of sentiment that had once attached to formal ownership of slaves. In many respects, post-Civil War peonage arrangements transformed forced laborers into the "disposable people" that Bales documents at length. The Court's first major translation of the Thirteenth Amendment, Pollock $v$. Williams, produced a substantive standard to analyze such claims. ${ }^{90}$ Under that standard, the Amendment forbids any state from making "the quitting of work any component of a crime, or

89. Bales, supra note 52 , at 5 . Bales identifies the increasingly prevalent practice of "contract slavery" as one of the more effective means of obscuring the true nature of the slave relationship:

Contract slavery shows how modern labor relations are used to hide the new slavery. Contracts are offered that guarantee employment, perhaps in a workshop or factory, but when the workers are taken to their place of work they find themselves enslaved. The contract is used as an enticement to trick an individual into slavery, as well as a way of making the slavery look legitimate. If legal questions are raised, the contract can be produced, but the reality is that the "contract worker" is a slave, threatened by violence, lacking any freedom of movement, and paid nothing. The most rapidly growing form of slavery, this is the second-largest form today. Contract slavery is most often found in Southeast Asia, Brazil, some Arab states, and some parts of the Indian subcontinent. Id. at 20 .

90. 322 U.S. 4 (1944). 
\begin{tabular}{lllll}
\hline \Server03\productn\CCOL $\backslash 102-4 \backslash$ COL403.txt & unknown & Seq: 22 & 7-MAY-02 & 17:50 \\
\hline
\end{tabular}

[Vol. 102:973

mak[ing] criminal sanctions available for holding unwilling persons to labor,"91 and applies (as the Court later explained) to all "situations in which the victim is compelled to work by law" or is subjected to compulsion through "physical ... coercion." 92 The peonage cases demonstrate that our commitment to these principles is indeed a serious one. But as yet we have no model for applying the standard we have developed to American corporations operating globally.

\section{Translation to the Global Economy}

It is again necessary, then, to translate the Thirteenth Amendment's prohibition on the existence of slavery to a new context for American industry. The present generation of U.S. corporations has begun to incorporate slave labor into American industry by locating the slave dependent components of their operations in foreign jurisdictions, just as industrialists at the turn of the century sought to accomplish that end by locating the slave dependent components of their operations in unobjectionable legal categories. Does the Amendment prohibit such practices? If so, how intimately must an American firm be involved in the exploitation of foreign slave labor in order to offend the Amendment? Finding answers to these distinctively modern questions requires us to turn back to some of America's earliest engagements with forced labor in order to determine the full content of the "slavery" that the Thirteenth Amendment has prohibited. ${ }^{93}$

\section{A. Analytical Foundations}

To set forth the foundations of my argument concerning the foreign slave practices of U.S. multinationals and the Thirteenth Amendment, I offer three propositions. Each is grounded in doctrinal principles that already find voice in the Court's engagement with slavery, both before and after emancipation. Understanding why these propositions are correct in turn helps to illustrate the conceptions of slavery-interpersonal, institutional, and industrial-that are embodied in the Thirteenth Amendment's prohibition.

1. Slavery and Slave Ownership as Social Relation. - My first proposition concerns slavery's operation on an interpersonal level. The relationship between the slave and the slave owner, and the impact that the ownership arrangement had upon each, was a matter of active concern in early discussions of slavery in both American and British legal circles. As contemporary legal thinkers understood it, the authorized possession of

91. Id. at 18 .

92. United States v. Kozminski, 487 U.S. 931, 942, 944 (1988).

93. Cf. Binder, supra note 5, at 2063-64 (arguing for "the relevance of remote and recent history to the meaning of the Thirteenth Amendment" and against position that it "secured little more than the manumission of slaves already practically freed by the friction of war"). 
complete dominion by one individual over another did more than simply create an enforceable property right in the enslaved individual. Such dominion created a social relation between owner and slave-a distinctive and robust interaction that the law of slavery recognized and took account of. In declaring that slavery and involuntary servitude "shall not exist" in the United States, the Thirteenth Amendment took aim, not just at the legal recognition of property rights in a slave, but also at the social relation of dominance that characterized both participants in the slave relationship. The Amendment's eradication of this interpersonal feature of slavery provides the foundation for my first proposition:

Proposition 1: The Thirteenth Amendment prohibits a citizen of the United States from owning a slave, regardless of where the enslaved individual is physically located.

A rich description of the relationship of dominance inherent in slavery may be found in the writings of one of its most notorious apologists, Judge Thomas Ruffin of the Supreme Court of North Carolina, in his opinion in State $v$. Mann. ${ }^{94}$ The case involved a criminal prosecution against John Mann, who had shot and wounded a slave, Lydia, hired to him by her owner. ${ }^{95}$ Mann was convicted of assault and battery, but the North Carolina Supreme Court overturned the conviction, finding that the law was required to take cognizance of the complete relationship of dominance that a master necessarily exercised over a slave:

The end [of slavery] is the profit of the master, his security and the public safety; the subject, one doomed in his own person, and his posterity, to live without knowledge, and without the capacity to make anything his own, and to toil that another may reap the fruits. ... [S] uch services can only be expected from one who has no will of his own; who surrenders his will in implicit obedience to that of another. Such obedience is the consequence only of uncontrolled authority over the body. There is nothing else which can operate to produce the effect. The power of the master must be absolute, to render the submissions of the slave perfect. . . This discipline belongs to the state of slavery. . . . [I] $\mathrm{t}$ is inherent in the relation of master and slave. ${ }^{96}$

94. 13 N.C. (2 Dev.) 263 (1829).

95. Id. at 263 .

96. Id. at 266-67. A federal district court in Ohio offered a similar description shortly following the enactment of the Thirteenth Amendment:

[U]nconditional submission of the slave is due to the authority of the master; and the master may, therefore, use such force and means as may be necessary to enforce submission to his authority, even to the destruction of life or limb of the slave. The law of slavery is absolute authority on the part of the master, and unconditional submission on the part of the slave. And the master may punish the slave at will, in such manner and degree as his judgment and humanity may dictate, provided he does not maim or kill. The right of the master to obedience and submission in lawful things is perfect. The power to inflict any punishment not affecting life or limb, which the master considers necessary to enforce obedience to his commands, is secured to him by the law. Now, if in the exercise 


\begin{tabular}{lllll}
\hline \Server03\productn\CCOL $\backslash 102-4 \backslash$ COL403.txt & unknown & Seq: 24 & 7-MAY-02 & 17:50 \\
\hline
\end{tabular}

In his important study of the American law of slavery in the nineteenth century, Professor Mark Tushnet explains that this social relation was distinct in part because of its totalistic quality-the embedded requirement that the master and slave concern themselves with every aspect of each other's lives. ${ }^{97}$

The ill effects of this relationship of dominance upon the slave were clear-Judge Ruffin complains of the "harshness" of the arrangement even as he reaffirms its ascendance ${ }^{98}$-and humanitarian reactions of sympathy for the enslaved individual lay at the heart of at least some abolitionist sentiment. But the effects that the social relation of slavery had upon the master were also a matter of concern for legal thinkers during the age of American slavery. The slave relationship placed the good character and morals of the owner in jeopardy. While this concern may ring hollow in the ears of contemporary readers when compared to the miseries inflicted upon enslaved individuals, it sounded loudly at the time. One of the principal evils of slavery, as eighteenth- and nineteenth-century opponents understood it, was the corrupting influence that this social relation of dominance threatened to exert upon the free whites who participated in it as owners and masters.

of his authority, the slave resists and slays the master, it is murder, and not manslaughter, because the law cannot recognize the violence of the master as a legitimate provocation.

Wood v. Ward, 30 F. Cas. 479, 482 (S.D. Ohio 1879) (No. 17,966) (citations omitted); see also Jacob v. State, 22 Tenn. (3 Hum.) 493, 520 (1842) (“[T] he right to obedience and submission, in all lawful things . . . is perfect in the master . ...”); Amar \& Widawsky, supra note 47, at 1370 ("That slavery was at root a power relation, involving the domination of the master and the degradation of the slave, was not lost on antebellum judges.").

Contemporary abolitionists described the relationship in similar terms, though obviously drawing very different conclusions. See, e.g., William Goodell, The American Slave Code 155 (William Loren Katz \& James M. McPherson eds., Arno Press 1969) (1853) ("We have seen that 'the legal relation' of slave ownership, being the relation of an owner to his property, invests him with unlimited power.").

97. Mark V. Tushnet, The American Law of Slavery 1810-1860, at 6 (1981). Tushnet contrasts the social relation of slavery with the more limited form of interaction typical of participants in a market:

Social relations in slave society rest upon the interaction of owner with slave; the owner, having total dominion over the slave, relates to the entire personality of the slave. In contrast, bourgeois social relations rest upon the paradigmatic instance of market relations, the purchase by a capitalist of a worker's labor power; that transaction implicates only a part of the worker's personality. Slave social relations are total, engaging the master and the slave in exchanges where each must take account of the entire range of belief, feeling, and interest embodied in the other; bourgeois social relations are partial, requiring only that participants in a market evaluate their general productive characteristics without regard to aspects of personality unrelated to production. Ways of interpreting slave conduct are developed from slave social relations and are ultimately embodied in the law....

Id.

98. Mann, 13 N.C. (2 Dev.) at 266. 
Concern over this baleful influence among owners and masters played a role in several interjurisdictional cases, in which courts in free jurisdictions were called upon to determine the extent to which slavery could be tolerated within their bounds in some mediated form-either on a transitory basis, as when slave owners sought to travel in the jurisdiction temporarily with slaves in tow, or on an attenuated basis, as when citizens of the free state owned slaves located elsewhere. In placing limits on even the mediated presence of slavery within their boundaries, the courts of some free jurisdictions relied in part upon the nature of the social relation that attends the slave system. These courts found that the goal of excluding "slavery" from the jurisdiction could not be accomplished without targeting both halves of the social relation: owner and enslaved individual.

The roots of this understanding may be found in Somerset $v$. Stewart, ${ }^{99}$ surely the most important interjurisdictional slavery case in Britain or America before Dred Scott itself. The case arose in England in 1772, when slavery had essentially been abolished in that country, ${ }^{100}$ and concerned the question of whether a slave from another jurisdiction could sue for freedom upon being brought to free English soil by his owner. Somerset, the slave, was brought to England by Stewart, his owner, a resident of Virginia who had acquired Somerset in Jamaica. It was Stewart's intention to transact some business in England and then travel to Jamaica with Somerset and sell him again; but Somerset, having been left in the care of one Captain Knowles, obtained local assistance to petition for a writ of habeas corpus that would free him from bondage. ${ }^{101}$

There was no question that Stewart held title of ownership to Somerset under the laws of Virginia; the question was whether that legal relation was subject to enforcement in the English courts when Stewart brought Somerset to England. Lord Mansfield found that it was not: The exclusion of slavery from English shores necessarily prohibited the enforcement of the master-slave relationship on even a transitory basis, and hence the courts of England were obliged to grant Somerset his freedom. ${ }^{102}$

Somerset set forth two interrelated doctrinal principles that are important for present purposes. The first was the requirement that the subjugation of the slave be sustained by positive legal enactment. Somerset's holding-that a slave could sue for freedom when brought to English soil-

99. 98 Eng. Rep. 499 (K.B. 1772).

100. There may have remained some vestiges of the English practice of "villenage"-a system of bonded servitude held over from feudal days-at this time. The continued vitality of villenage was a matter of dispute between the parties in the Somerset case. In its opinion, the court entertained the possibility that the legal status of villenage might still exist in some form in England, but considered the matter irrelevant to its disposition of the case. Id. at 500, 510 .

101. Id. at 499 .

102. Id. at 510 . 
rested on the conclusion that because the slave relation had no grounding in natural law, it could be sustained, if at all, only by municipal regulations in the forum where the slave relationship was sought to be enforced. ${ }^{103}$ This question of positive law, and the doctrine of comity that Lord Mansfield invoked in resolving it, were the principle issues with which the Somerset court was concerned, and they are the propositions for which the case is usually cited. Intimately bound up with that holding, however, was the related issue of the legal origins of the master-slave relation: When a recognizing forum does provide positive legal support for the slave relation of another jurisdiction, what is the nature of the legal relation it is supporting? As future courts would go on to discuss more explicitly, a regulation that supports the slave relation is upholding a legally enacted "status." 104 As with the marital relation, the slave relation governed the personhood and citizenship status of each participant before the law. Under the nascent choice of law doctrines of the nineteenth century, enactments affecting an individual's personhood or citizenship proceeded primarily from the law of the person's domicile, ${ }^{105}$ and this precept held equally true for the status of participants in the slave relation. ${ }^{106}$ As a practical matter, this generally meant that the slave

103. Justice Story later echoed this pronouncement for the Supreme Court in Prigg v. Pennsylvania, 41 U.S. (16 Pet.) 539, 611 (1842) (" $[\mathrm{N}]$ o nation is bound to recognise the state of slavery, as to foreign slaves found within its territorial dominions, when it is in opposition to its own policy and institutions ....”).

104. Commonwealth v. Aves, 35 Mass. (18 Pick.) 193, 217 (1836); Lemmon v. People, 20 N.Y. 562, 603-04 (1860).

105. As Justice Story wrote in his Commentaries:

$[\mathrm{M}]$ arriage [unlike other contracts] is a contract sui generis, and the rights, duties, and obligations, which arise out of it, are matters of so much importance to the well-being of the State, that they are regulated, not by the private contract, but by the public laws of the State, which are imperative on all, who are domiciled within its territory. If a man in this country were to confine his wife in an iron cage, or to beat her with a rod of the thickness of the Judge's finger, would it be a justification in any court, to allege, that these were powers, which the law of England conferred on a husband, and that he was entitled to the exercise of them, because his marriage had been celebrated in that country?

Joseph Story, Commentaries on the Conflict of Laws, Foreign and Domestic, ch. V, $\$ 111$ (3d ed. 1846). The civil status of married parties under the incidents of the marital relationship is not to be confused with the validity of the marriage itself, which is generally governed by the place of celebration. Id. ch. V, $\S 113$.

The advocates for the losing party in Somerset themselves invoked the similarity in legal structure between the slave and marital relations, arguing that a victory for Somerset would suggest that a hostile forum would also be empowered to disregard a foreign marriage. Somerset, 98 Eng. Rep. at 506 ("The relation of husband and wife, I think myself warranted in questioning, as a natural relation: does it subsist for life; or to answer the natural purposes which may reasonably be supposed often to terminate sooner? Yet this is one of those relations which follow a man every where.").

106. Story, supra note 105 , ch. IV, $\S 96$ (noting the "uniformity of opinion among foreign jurists ... in giving no effect to the state of slavery of a party, whatever it might have been in the country . . . in which he had been previously domiciled, unless it is also recognised by the laws of the country of his actual domicil”); Aves, 35 Mass. (18 Pick.) at 
relation was governed by the law of the master's domicile. ${ }^{107}$ In Somerset itself, for example, the court indicated that Stewart remained a domiciliary of Virginia, ${ }^{108}$ and hence that it was the laws of Virginia that would govern the relation between Somerset and Stewart unless denied enforcement by the courts of England. ${ }^{109}$

This second doctrinal principle concerning the legal status of the master under the law of his domicile, though often discussed only in passing, forms an important component of the legal framework within which interjurisdictional cases like Somerset operated. Rendered more precisely, the question posed in the interjurisdictional cases was whether there existed any basis in the positive law of the second forum (England, in the case of Somerset) for recognizing and enforcing the legal statuses of "master" and "slave" brought into being under the law of the first, domiciliary forum. The slave relation, in other words, had to be supported both by the positive legal enactments of the owner's domicile and by the positive legal enactments of any jurisdiction to which the slave was physically transported. The result in Somerset flowed from that court's conclusion that a sovereign possessed the right to regulate the status not only of its domiciliaries, but also of people physically traveling within its territory, and thus could deny positive legal support to the status of "master" or "slave" created by another jurisdiction. ${ }^{110}$

In explaining its holding, the Somerset court embraced a characterization of the slave relation that would influence the analysis in subsequent interjurisdictional cases. Mansfield rested his conclusion about the positive law foundations of the slave relation on the conclusion that

The state of slavery is of such a nature, that it is incapable of being introduced on any reasons, moral or political; but only positive law, which preserves its force long after the reasons, occasion, and time itself from whence it was created, is erased

217 (explaining that "status, or condition" of slave is determined first by law of domiciliary state).

107. See, e.g., Scott v. Sanford, 60 U.S. (19 How.) 393, 462 (1857) (describing domicile of Dred Scott, which followed that of his owner).

108. Somerset, 98 Eng. Rep. at 510 ("Mr. Stewart, having occasion to transact business, came over hither, with an intention to return [to Virginia] ....").

109. Id. at 509 ("The now question is, whether any dominion, authority or coercion can be exercised in this country, on a slave according to the American laws?"); id. at 510 ("The captain of the ship on board of which the negro was taken, makes his return to the writ in terms signifying that ... the trade in [slaves] is authorized by the laws and opinions of Virginia and Jamaica; that they are goods and chattels; and, as such, saleable and sold."). The allusion to Jamaican law in the second passage refers to the legality of both the original contract of sale for Somerset and his anticipated resale by Stewart-issues that the court had touched upon earlier in its opinion. Id. at 509.

110. See Lemmon v. People, 20 N.Y. 562, 603-04 (1860) (asserting "the right of a sovereign State to determine the status of persons within its jurisdiction" and discussing that principle in light of Somerset). 
from memory: it's so odious, that nothing can be suffered to support it, but positive law. ${ }^{111}$

In his short opinion explaining the disposition of the case, Mansfield does not expand upon those aspects of slavery that are so "odious" as to require this result. But that issue is squarely addressed in the arguments of Francis Hargrave, Somerset's counsel, which alone are endorsed by the court and singled out for particular praise among those arguments reproduced with the opinion. ${ }^{112}$ Hargrave explains that the slave relation exerts deleterious effects upon the owner as well as the slave:

Let us reflect on the consequences of servitude in a light still more important. The corruption of manners in the master, from the entire subjection of the slaves he possesses to his sole will; from whence spring forth luxury, pride, cruelty, with the infinite enormities appertaining to their train; the danger to the master, from the revenge of his much injured and unredressed dependent; debasement of the mind of the slave, for want of means and motives of improvement; and peril to the constitution under which the slave cannot but suffer, and which he will naturally endeavour to subvert, as the only means of retrieving comfort and security to himself. 113

The institution of slavery was "odious," not merely for the misery that it inflicted upon the slave, but also for the threat that it posed to the character and morals of the master. In this assertion, Hargrave drew upon a vocabulary of slavery that was well established. ${ }^{114}$ Thomas Jefferson (himself a slave owner) ${ }^{115}$ embraced similar sentiments in his contemporaneous Notes on Virginia, in which he decried the impact that the

111. Somerset, 98 Eng. Rep. at 509.

112. The prefatory materials to the opinion of the Court report:

Upon the second argument, (Ser[g]eant Glynn was in the first, and, I think,

Mr. Mansfield) the pleading on behalf of the negro was opened by Mr. Hargrave.

I need not say that it will be found at large, and I presume has been read by most of the profession, he having obliged the public with it himself: but I hope this summary note, which I took of it at the time, will not be thought impertinent; as it is not easy for a cause in which that gentleman has appeared, not to be materially injured by a total omission of his share in it. Id. at 499

As this excerpt implies, Hargrave published the full text of his argument as a pamphlet, which still exists. Francis Hargrave, An Argument in the Case of James Sommersett a Negro, reprinted in 1 Slavery, Race and the American Legal System, 1700-1872: Southern Slaves in Free State Courts 1, 1-82 (Paul Finkelman ed., 1988) [hereinafter Slavery and Race].

113. Somerset, 98 Eng. Rep. at 500.

114. Professor Ashworth gives primacy of place to the social relation between master and slave in his discussion of the gradual move toward abolition, asserting that during antislavery debates, "the relationship between slave and slaveholder, rather than the mere existence of the market, was at the center of attention.” John Ashworth, Capitalism, Class, and Antislavery, in The Antislavery Debate: Capitalism and Abolitionism as a Problem in Historical Interpretation 276, 276-80 (Thomas Bender ed., 1992). (1996).

115. Joseph J. Ellis, American Sphinx: The Character of Thomas Jefferson 144-52 
exercise of dominance in a slave relationship had upon the morals and character of the master:

The whole commerce between master and slave is a perpetual exercise of the most boisterous passions, the most unremitting despotism on the one part, and degrading submissions on the other. Our children see this, and learn to imitate it. ... The man must be a prodigy who can retain his manners and morals undepraved by such circumstances. And with what execration should the statesman be loaded, who, permitting one half the citizens thus to trample on the rights of the other, transforms those into despots, and these into enemies, destroys the morals of the one part, and the amor patriae of the other. ${ }^{116}$

And these harms in turn corresponded to the two sources of positive law necessary to support the slave relation in an interjurisdictional case: the law of the forum where the slave was located, necessary to impose an unnatural and injurious state of servitude upon the slave; and the law of the master's domicile, necessary to invest the master with an unnatural and dangerous power of dominance.

The result in the Somerset case resounded throughout subsequent legal analyses of interjurisdictional slavery disputes in America. Most of Somerset's progeny focused principally upon its holding that the positive law of the forum is necessary to support the servitude of a slave. Thus, in the free States of Massachusetts and Ohio, courts embraced Somerset and held that a slave may secure his freedom when his owner voluntarily brings him to free soil. ${ }^{117}$ And those who would deny the ability of slaves

116. Thomas Jefferson, Notes on Virginia: 1781-1782, in 8 The Writings of Thomas Jefferson 403-04 (H.A. Washington ed., Washington, Taylor \& Maury 1854). As Professor Ellis explains, Jefferson later stepped away from these abolitionist sentiments, which were not intended for an American audience and did not sit comfortably with the elite members of Virginia gentility. See Ellis, supra note 115, at 145-47.

117. Commonwealth v. Aves, 35 Mass. (18 Pick.) 193, 210-11 (1836); Birney v. State, 8 Ohio 230, 236-37 (1837); see also Lemmon v. People, 20 N.Y. 562, 615 (1860) (same result for New York).

The Supreme Court of Louisiana (a slave state) adopted one of the most aggressive interpretations of the Somerset principle. In Marie Louise, F.W.C. ["Free Woman of Color"] v. Marot, 9 La. 473, 474 (1835), the court considered a claim for freedom brought by Marie Louise, a slave owned by a citizen of Louisiana. Louise had been brought by her owners to France, which was then a free jurisdiction. Upon returning with her owners to Louisiana, Louise sued for her freedom, claiming that her transport to a free jurisdiction had severed the bonds of slavery. The court agreed, issuing the broad holding that "Being free for one moment in France, it was not in the power of her former owner to reduce her again to slavery." Marie Louise, 9 La. at 476.

This result was the consequence of the positive law approach to the institution of slavery. Even among states that continued to defend the institution of slavery, there was an emerging recognition (or admission) that slavery was not a "natural" status-that is, not a relationship that reflected deeper truths in the relationship between living things in the world. Thus, slavery could only be supported by positive legal enactments-it had no independent grounding in the natural law tradition. See, e.g., id. An aggressive reading of this position held that the status of slave and master had to be supported at all times by positive legal enactments. If it ceased to be supported by positive legal enactments at any 
to sue for their freedom after being brought into free jurisdictions-including, ultimately, the Supreme Court in Dred Scott itself-felt obliged to respond to Somerset and distinguish or reject it. ${ }^{118}$ In such cases, the role of the master's domicile remained largely implicit. But one of the most prominent of Somerset's progeny-the opinion of the New York Court of Appeals in Lemmon v. People-placed explicit reliance upon the interrelationship between positive legal enactment, citizenship status, and the twofold impact of the slave relation upon both master and slave. ${ }^{119}$

In Lemmon, a slave owner voluntarily brought a slave to the free jurisdiction of New York to initiate the ocean-going leg of a trip between Virginia (where the owner resided) and Texas. Like the courts of Massachusetts, Ohio, and others before it, ${ }^{120}$ the New York Court of Appeals embraced Somerset and held that a slave becomes free when his owner voluntarily brings him to free soil. In Lemmon, however, the court explicitly grounded its holding in an extended discussion of the social relation between master and slave, which, the court found, the legislature had absolutely abolished from the State of New York. The court acknowledged that the social relation of slavery flowed from the power of the domiciliary state to "determine and regulate the status or social and civil condition of her citizens"121 — a power that necessarily followed the domicile of the master, since "slaves certainly are not citizens." 122 In refusing to permit the transport of slaves through New York, the Lemmon court found that the New York legislature had completely forbidden the status of either slave owner or slave to exist within the polity or territory of New York. This was so, the members of the majority explained, because even a mediated or attenuated presence of slavery would bring with it the social relation that constituted one of the evils that New York had sought to exclude:

moment, the relation failed entirely and could not be revived by the subsequent restoration of legal support. In an era when conflict of laws principles were almost entirely territorial in their operation, this reading held that a slave who was transported to a free jurisdiction immediately became free, even if she did not sue for her freedom until she returned to the state that had enslaved her. See, e.g., Prigg v. Pennsylvania, 41 U.S. 539, 611 (1842) (Story, J.) (describing necessity for support of slave relationship by positive law); Christopher L.M. Eisgruber, Justice Story, Slavery, and the Natural Law Foundations of American Constitutionalism, 55 U. Chi. L. Rev. 273, 280 \& n.24 (1988) (discussing Prigg and Somerset). The English courts themselves did not adopt such an aggressive position, holding that a slave had to sue for her freedom in England in order to take advantage of the Somerset holding. The Slave, Grace, 166 Eng. Rep. 179, 183 (Adm. 1827).

118. See, e.g., Scott v. Sandford, 60 U.S. (19 How.) 393, 485 (1856) (Daniel, J., concurring); Aves, 35 Mass. (18 Pick.) at 196-205 (reproducing arguments of counsel seeking to distinguish Somerset).

119. 20 N.Y. at $603-10$.

120. See Milly v. Smith, 2 Mo. 36, 38 (1838); supra note 117. See also Ellis v. Welch, 38 S.C.L. (4 Rich.) 468, 476-78 (S.C. Ct. App. 1851) (assuming that Somerset doctrine would apply in Pennsylvania or New York and finding that master of vessel must employ high standard of care when determining whether Negro passengers are slaves).

121. Lemmon, 20 N.Y. at 616.

122. Id. at 610 . 


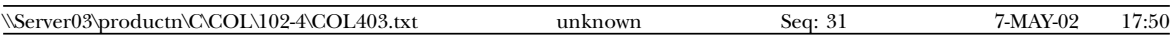

It is not denied that New York has effectually exerted her sovereignty to the extent that the relation of slave owner and slave cannot be maintained by her citizens, or persons or citizens of any other State or nation domiciled within her territory ..., and that this she might rightfully do. ... [W] hen the domestic laws reject and suppress the status [of slave and slave owner] as a civil condition or social relation, as matter of reason and authority it is never upheld in the case of strangers resident or in transit. ${ }^{123}$

A further logical consequence of this holding would seem to be that citizens of New York were absolutely prohibited from owning slaves, even if the enslaved individuals were located elsewhere. The foundation of the interjurisdictional cases, made explicit by Lemmon, is that the slave relation must be supported both by the positive legal enactments of the owner's domicile and by the positive legal enactments of any state to which the slave is physically transported. The law of the domicile creates the status of "master" and "slave," while the law of the forum is required to maintain those statuses against the natural state of liberty in which men and women otherwise exist, and the basis of the Lemmon court's decision concerning slaves in transit was that "New York has effectually exerted her sovereignty to the extent that the relation of slave owner and slave cannot be maintained by her citizens, or persons or citizens of any other State or nation domiciled within her territory." ${ }^{24}$ By the terms of the court's opinion, the positive legal authority to enjoy the status of "slave owner" was removed from domiciliaries of New York.

While Lemmon does not squarely address this consequence of New York's abolition of the social relation of slavery (not surprisingly, since the case dealt only with an owner from a slave state who physically transported her slave through New York), the proposition that New York citizens may not own slaves does appear to be embedded in the laws of the state and reaffirmed by the Lemmon majority. In discussing the reasons for its holding concerning slaves in transit, for example, the court explains that, if an out of state resident were permitted to bring a slave through the jurisdiction, one consequence would be that, "as one of the chief attributes of property," she could "sell or dispose of" that slave. ${ }^{125}$ A New York resident, however, could not be the purchaser:

[The out of State owner] could not, perhaps, sell them to a citizen of New York, who would at all events be bound by our laws, but any other citizen of a slave State-who would equally bring with him the immunities and privileges of his own State-might lawfully traffic in the slave property. ${ }^{126}$

123. Id. at 617-18 (opinion of Wright, J.).

124. Id. at 617 .

125. Id. at 610 .

126. Id. 
The laws of New York, in other words, forbade New York citizens from purchasing slaves, even in circumstances where the resident of a slave state could legally do so. A similar prohibition is reflected in earlier versions of the laws regulating the transitory presence of slaves in the State. In 1830, for example, the legislature reenacted laws prohibiting the importation of slaves into New York but made an exception for slaves carried through the State on a transitory basis. ${ }^{127}$ That exception, however, was available only to inhabitants of other states. It read:

Any person, not being an inhabitant of this State, who shall be traveling to or from, or passing through this State, may bring with him any person lawfully held in slavery, and may take such person with him from this State; but the person so held in slavery shall not reside or continue in this State more than nine months; if such residence be continued beyond that time such person shall be free. ${ }^{128}$

(The 1841 law that governed the dispute in Lemmon eliminated this exception.) ${ }^{129}$ Inhabitants of New York, unlike out-of-staters, were never allowed to have slaves within the State, even on a transitory basis. ${ }^{130}$ Thus, the law of New York apparently forbade to its residents all of the incidents of slavery, including any form of participation in the masterslave relation. ${ }^{131}$

Lemmon is also worthy of special note in that, unlike its predecessors, the New York court rendered its decision following the Supreme Court's decision in Dred Scott-and, it would not be an exaggeration to say, in open defiance of that decision. The Court in Dred Scott had recognized a

127. See id. at 601 (discussing N.Y. Rev. Stat., pt. 1, ch. 20, tit. 7 (1836)).

128. Id. (quoting N.Y. Rev. Stat., pt. 1, ch. 20, tit. 7, §6 (1830)). See also id. at $618-19$ (explaining evolution of New York antislavery laws containing exceptions that applied only to "an inhabitant of another State").

129. See id. at 601-02.

130. Such an approach was almost certainly influenced by Quaker abolitionist sentiments, which played an influential role in shaping antislavery attitudes in the North. As Professor Davis writes, "It would be difficult to exaggerate the central role Quakers played in initiating and sustaining the first antislavery movements." David Brion Davis, The Quaker Ethic and the Antislavery International (1975), reprinted in The Antislavery Debate, supra note 114, at 27, 29. Before the founding of the Republic, Northern Quakers adopted a policy requiring their members to take all possible steps to manumit slaves and forbidding them to participate, even indirectly, in their sale or transfer. Id.

131. New York embraced such a strong abolitionist sentiment only after contending with the issue of slavery for many years. See generally Alvin Kass, Politics in New York State 1800-1830, at 81-89 (1965) (describing slow and highly politically charged process by which New York legislated general emancipation). The uncompromising policy revealed in Lemmon was the result of a very gradual ratcheting up of New York antislavery laws. See Lemmon, 20 N.Y. at 600-02. And even after adopting an official stance of prohibition, New York still served as one of the major centers for the outfitting of ships engaged in the illicit slave trade. See Ernest A. McKay, The Civil War and New York City 13-15 (1990) (describing continued economic benefits to New York of slave labor and slave trade, and popular resistance to dictates of emancipation); infra notes 160-163 and accompanying text. 
slave owner's interest in his slaves (the res of the master-slave relationship) as a robust property right with deep constitutional foundations. ${ }^{132}$ That holding called into serious question the ability of free states to abrogate the property rights of transient slave owners or otherwise to restrict their movement, as states like Ohio and Massachusetts had done through the decisions of their highest courts. ${ }^{133}$ Lemmon was a deliberate statement of resistance to Dred Scott. Indeed, as Professor Finkelman has written, Lemmon would likely have been overruled by the Supreme Court had the Civil War not overtaken events. ${ }^{134}$ And Dred Scott, in turn, was one of the statements of law that the Union most explicitly rejected when it enacted the Reconstruction Amendments.

Thus, in the wake of Dred Scott, the character of slavery as a social relation was distinctly present in the American legal vocabulary. As Hargrave had put it one hundred years earlier in terms that continued to galvanize slavery opponents, that relation could lead to the "corruption of manners in the master" and threatened to produce in him "luxury, pride [and] cruelty, with the infinite enormities appertaining to their train." ${ }^{35}$ Thus it was that the New York Court of Appeals, in continuing to resist the incursion of slavery following Dred Scott, took deliberate aim at both the status of "slave" and the status of "master" within New York.

This concern over the "corruption of manners" among employers and industrialists also continued to find voice in the ratification debates for the Thirteenth Amendment, in discussions over both the moral and economic imperatives demanding the elimination of slavery and all its vestiges. As Professor VanderVelde has demonstrated, one serious concern among the members of Congress who debated the Amendment was the hostile climate that the slave system created toward free Southern laborers, including poor whites. ${ }^{136}$ The existence of slavery, these legisla-

132. See Scott v. Sandford, 60 U.S. (19 How.) 393, 425 (1856) ("The only two provisions [of the Constitution] which point to [Africans brought to America] and include them, treat them as property, and make it the duty of the government to protect [that property] ....").

133. As one dissenting judge wrote in Lemmon:

If, then, by the law of nations, the citizen of one government has a right of passage with what is recognized as property by that law, through the territory of another, peaceably, and that too without the latter's acquiring any right of control over the person or property, is not a citizen of any State of this confederacy entitled, under the compact upon which it is founded, to a right of passage through the territory of any other State, with what that compact recognises as property, without the latter's acquiring any right of control over that property.

Lemmon, 20 N.Y. at 641 (Clerke, J., dissenting).

134. Paul Finkelman, Introduction to Slavery and Race, supra note 112, at xiii.

135. Somerset v. Stewart, 98 Eng. Rep. 499, 500 (K.B. 1772); see also Robertson v. Baldwin, 165 U.S. 275, 292 (1897) (Harlan, J., dissenting) ("Slavery exists wherever the law recognizes a right of property in a human being, but slavery cannot exist in any form within the United States."). 
tors argued, "degraded labor," even among free populations, by inspiring employers to act with impunity toward vulnerable workers. The slave system's "corruption of morals" in the master and the industrialist reinforced them in the exploitation of laborers generally. ${ }^{137}$ As one legislator put it, the system of slavery perpetuated "the atrocious sentiment that it was better for society that the capitalists of the country should own the laborers, whether white or black" and thereby "degrade the laboring classes to a condition below that of the peasantry of Europe and render it impossible for them to rise in society." 138

Following Reconstruction, as the need arose to translate the command of the Thirteenth Amendment to address the emerging practice of peonage, courts continued to recognize this concern over the corruption of manners in those who exploit forced labor as one of the Amendment's central principles. Thus, in explaining that debt slavery violates the Thirteenth Amendment, a federal district court in Alabama wrote of the emerging peonage schemes:

The improvidence and the needs of laborers and servants, the greed of employers, and the exercise, often corrupt, of almost irresponsible power of local magistrates, resulted in citizens becoming bound, in constantly increasing numbers and length of service, to compulsory "service or labor" to coerce payment of debt or compel the performance of real or pretended obligations of personal service. The evils of the system not only degraded those who were subjected to the system, but exercised a baleful influence upon all other classes, which in innumerable ways fought against the industrial prosperity and moral advancement of the people among whom the "system" [of peonage] was enforced. It was wholly out of keeping with the spirit of the amendment to the Constitution, which forbids involuntary servitude, except upon due conviction of crime. ${ }^{139}$

These evils, the court went on to emphasize, were equally "productive of public ill when brought about by lawless force on the part of individuals, as when upheld by state or territorial law or custom." 140

137. See id. at 472-73 \& 472 n.150 (canvassing expressions of concern among members of Congress during ratification debates).

138. Id. at 472 (quoting Cong. Globe, 38th Cong., 1st Sess. 2955 (1864) (remarks of Francisco Kellogg of Michigan) (alteration in original)).

139. The Peonage Cases, 123 F. 671, 674-75 (M.D. Ala. 1903); see also United States v. Booker, 655 F.2d 562, 566 (4th Cir. 1981) (holding that federal antislavery statute passed shortly after enactment of Thirteenth Amendment "must be read not only to render criminal the evil Congress sought to eradicate so long ago but, as well, its Twentieth Century counterpart").

140. Peonage Cases, 123 F. at 677 . Judge Easterbrook expressed a similar sentiment in American Booksellers Ass'n v. Hudnut:

People often act in accordance with the images and patterns they find around them. People raised in a religion tend to accept the tenets of that religion, often without independent examination. People taught from birth that black people are fit only for slavery rarely rebelled against that creed; beliefs coupled with the 
The wages of slavery and forced labor, in other words, included a threat of cascading impacts flowing from the relation of master and slave. This was true wherever dominance and subservience was enforced through threat of prosecution or violence, whether the relation was one of true chattel slavery or episodic forced labor. That relation constituted both an intrinsic evil, in the immediate harms that it inflicted upon the slave, and a secondary evil, in the behaviors that it inspired in the master. The Thirteenth Amendment aimed to eradicate both ills. It was against this background that the Court pronounced in the Slaughter-House Cases that, "In [the] struggle [of the Civil War] slavery, as a legalized social relation, perished." 141

I observed earlier that the Thirteenth Amendment, free of any state action requirement, imposes substantive limitations upon the nature of the private social and economic relationships that can exist within the United States. ${ }^{142}$ The opinion of the majority in the Lemmon case, issued in open defiance of Dred Scott, helps to illuminate a part of what those substantive limitations must entail. The status of "slave owner" or "master"; the enjoyment of an "entire subjection" of another human being under one's "sole will"; these were among the distinct and independent evils associated with slavery that those who drafted the Thirteenth Amendment sought to eradicate. As the Supreme Court went on to say in Bailey $v$. Alabama, one of the peonage cases discussed earlier:

The plain intention [of the Thirteenth Amendment] was to abolish slavery of whatever name and form and all its badges and incidents; ... . to make labor free, by prohibiting that control by which the personal service of one man is disposed of or

self-interest of the masters established a social structure that inflicted great harm while enduring for centuries.

771 F.2d 323, 328-29 (7th Cir. 1985), aff'd, 475 U.S. 1001 (1986).

141. The Slaughter-House Cases, 83 U.S. 36, 68 (1872). In his treatise on the African slave trade, published thirty years after the enactment of the Thirteenth Amendment, W.E.B. Du Bois offers an affecting description of the impact of the slave relationship upon the morality of the owner or master:

An economic system based on slave labor will find, sooner or later, that the demand for the cheapest slave labor cannot long be withstood. Once degrade the laborer so that he cannot assert his own rights, and there is but one limit below which his price cannot be reduced. That limit is not his physical wellbeing, for it may be, and in the Gulf States it was, cheaper to work him rapidly to death; the limit is simply the cost of procuring him and keeping him alive a profitable length of time. Only the moral sense of a community can keep helpless labor from sinking to this level; and when a community has once been debauched by slavery, its moral sense offers little resistance to economic demand. This was the case in the West Indies and Brazil; and although better moral stamina held the crisis back longer in the United States, yet even here the ethical standard of the South was not able to maintain itself against the demands of the cotton industry.

W.E. Burghardt Du Bois, The Suppression of the African Slave-Trade to the United States of America 1638-1870, at 168-69 (La. State Univ. Press 1969) (1896).

142. See supra text accompanying notes 24-31. 
coerced for another's benefit which is the essence of involuntary servitude. ${ }^{143}$

Just as the State of New York prohibited its citizens from participating in the social relation of slavery, so the Thirteenth Amendment prohibits citizens and residents of the United States from enjoying a property interest in a laborer or otherwise exercising the complete dominion of a slave master. ${ }^{144}$ The Amendment eradicated the social relation of slavery in America. Of necessity, it eradicated both the status of "slave" and the status of "master" to accomplish this end.

2. Slavery as Interconnected Institution. - From the interpersonal, I turn next to the operation of slavery on an institutional level. It is a commonplace to refer to slavery as an "institution," particularly when referring to the "peculiar institution" of chattel slavery that existed in pre-Civil War America. The syntax aims at capturing the elaborate body of ritual and praxis that surrounded the systematic exploitation of involuntary labor in America. The American practice of slavery involved complementary bodies of ritual in both the public and private spheres. How these bodies of ritual interact-and, in particular, what institutional support structures enabled the practice of slavery to function-is a vital area of inquiry if one seeks to understand the interrelated issues of how legalized slavery operated before the Civil War and what body of practices the Thirteenth Amendment eradicated in the war's aftermath. My principal focus in this Part will be on one of the most notorious of the supporting institutions that permitted slavery to function, the foreign slave trade, and on the enforcement strategies that the Supreme Court ratified in the prosecutions that curtailed it. This inquiry into the "supporting institutions" of slavery provides the foundation for my second proposition:

Proposition 2: The Thirteenth Amendment prohibits U.S. entities from engaging directly in the business of supporting slavery, even if the enslaved individuals are located wholly within foreign jurisdictions.

The suggestion that one cannot understand slavery without understanding the interaction of multiple, intersecting institutions is not a new one. Professor Mark Tushnet's canonical work on the operation of slavery through the institution of law provides one example of such an inquiry. ${ }^{145}$ Tushnet has traced in detail the manner in which Southern slavery navigated between legal and domestic institutions. In the public sphere, elaborate legal doctrines governed the economic rights that both owners and third parties could claim with respect to the activities and disposition of slave laborers. In the private sphere, a body of hortatory ethical traditions, categorically referred to as "sentiment," arose to de-

143. 219 U.S. 219, 241 (1911).

144. Cf. Amar \& Widawsky, supra note 47, at 1383 ("For those who seek to vindicate substantive rights to real world protection, few provisions of the Constitution are as substantive or realist-concerned with de facto power-as the Thirteenth Amendment." (footnote omitted)).

145. Tushnet, supra note 97. 
scribe the obligations that a slave owner should understand himself to owe to the slaves in his charge. ${ }^{146}$ These traditions of law and sentiment naturally served multiple ends. For example, traditions of sentiment, in addition to providing norms for the governance of home life, also reinforced a presumption of privacy within the home that protected slave owners from having their domestic practices questioned by legal authorities. ${ }^{147}$ Nor did law and sentiment always operate in harmony, as Tushnet explains in great depth. ${ }^{148}$ Even so, this uneasy marriage of legally regulated market relations and jealously guarded personal prerogatives created a functional, if shifting, framework. The important observation for present purposes is that the existence of such bodies of tradition and doctrine was a necessary and inevitable element of the incorporation of slave labor into American industry. Despite collateral agendas that were at times incompatible, law and sentiment served their primary purpose: They formed complementary institutions that permitted slave relationships-and, hence, slave-dependent industries - to function in stable and predictable ways. ${ }^{149}$

A similar observation may be made about the more quotidian details of the practice of slavery. Just as slavery utilized an internal structure of institutional forms to promote its effective and stable operation, so it in-

146. Id. at $44-45$.

147. See, e.g., id. at 168-69 (discussing treatment of slaves in ownership disputes and explaining that "Although allowing state intervention in transactions between masters, [state courts' policy of treating all slaves alike] minimized the intrusion on master-slave relations, by eliminating detailed inquiry into individual relations").

148. Professor Tushnet convincingly argues that systems of regulation relying upon sentiment and systems of regulation relying upon law were deeply incompatible, giving rise to tensions that consistently plagued the administration of slave institutions in the South: Developing a stable body of law [in the slave South] proved extremely

difficult. ... The short explanation is that concern with humanity arose from one set of social relations whereas concern for [economic] interest arose from another set, and although those social relations coexisted in the slave South, they could not be integrated into a unified social formation, one that lacked internal contradiction. Id. at 6 .

Nonetheless, slavery functioned. Indeed, the institution survived longer than many expected at the founding of the Republic. Opponents of slavery accepted the constitutional compromise that permitted slavery to continue but authorized federal restrictions on the foreign slave trade twenty years after ratification in part because they believed that slavery would die a natural death once the trade was restricted. See Du Bois, supra note 141, at 61-65. For further discussion of these issues, see infra text accompanying notes 153-157.

149. Thus, in State v. Mann, the court explicitly justified its deference to the domestic prerogatives of the white male householder as necessary to the continued functioning of slavery:

We cannot allow the right of the master to be brought into discussion in the Courts of Justice. The slave, to remain a slave, must be made sensible that there is no appeal from his master; that his power is in no instance usurped; but is conferred by the laws of man at least, if not by the law of God.

13 N.C. (2 Dev.) 263, 267 (1829). 
teracted externally with other institutions that served to support and promote the slave system in its day to day operation. Consider, for example, the auction block-that powerfully symbolic stage on which enslaved people were displayed and sold in Southern slaveholding states. The block itself was an institutional form that was internal to the slave system, one of its devices. ${ }^{150}$ But auction blocks were typically located within external rituals-a town fair, for example, or a courthouse sale-that supported the auction block and enabled it to function by providing an occasion for potential purchasers to come together in an atmosphere conducive to commerce. ${ }^{151}$ Such an external ritual, in other words, operated as a "supporting institution" for the slave system and the auction block-a practice external to the institution of slavery itself that nonetheless served a vital role in permitting one of the forms of that institution to function. Again, interrelated systems of ritual and praxis contributed to the stable and effective exploitation of forced labor. ${ }^{152}$

This notion of "supporting institutions" is one that the pre-Reconstruction Supreme Court recognized and relied upon on in a series of decisions addressing one practice within the institution of slavery: the foreign slave trade. In the Slave Trade Cases, ${ }^{153}$ the Court confronted the question of what types of activities constituted sufficient evidence to support a forfeiture proceeding for participation in the foreign slave trade. The Court's conclusion in these cases rested on a recognition of the role that certain supporting institutions, external to the trade in slaves itself, played in enabling the trade to function and remain profitable. Before examining the Slave Trade Cases in detail, however, a brief description of the history of the slave trade in America is in order.

The relationship between the domestic institution of slavery and the foreign slave trade during the seventy-five years between the ratification of the Constitution and the signing of the Emancipation Proclamation was a complicated one. Contrary to the conventional wisdom of an abolitionist North and a slave-supporting South, attitudes (both official and un-) toward the continuation of the slave trade did not divide neatly by region, nor did they remain constant throughout the first half of the nineteenth century. Powerful economic interests in the North sometimes favored the continuation of the trade, much of which passed through Northern ports, while Southern interests, both economic and social, strongly opposed the trade at times. By the same token, the official status

150. Thomas D. Russell, A New Image of the Slave Auction: An Empirical Look at the Role of Law in Slave Sales and a Conceptual Reevaluation of Slave Property, 18 Cardozo L. Rev. 473, 473-75 (1996).

151. See id. at $485-88$ (describing courthouse sales).

152. See id. at 473-74 (describing slave auctions as rituals that "reinforced the subordinate position of slaves in Southern society").

153. The cases were handed down as companion decisions and include The Slavers (Kate), 69 U.S. (2 Wall.) 350 (1864); The Slavers (Sarah), 69 U.S. (2 Wall.) 366 (1864); The Slavers (Weathergage), 69 U.S. (2 Wall.) 375 (1864); The Slavers (Reindeer), 69 U.S. (2 Wall.) 383 (1864). I will refer to these decisions collectively as the "Slave Trade Cases." 
of the slave trade as a prohibited enterprise for most of the nineteenth century often bore little relationship to the reality of a vigorous and pervasive clandestine trade. For decades, efforts by federal officials to police the trade were sporadic and half hearted, even as the ban on domestic slavery in Northern states became an increasingly divisive issue. A basic understanding of these internal contradictions is an important prerequisite to appreciating the enforcement strategies that the Court ultimately validated in the Slave Trade Cases.

For the first twenty years of the Republic, the regulation of the foreign slave trade rested entirely in the hands of the states. Article I of the Constitution empowered Congress to pass laws forbidding the trade, but only following the year $1808 .{ }^{154}$ It was, of course, the Southern states that insisted upon this compromise, using the threat of constitutional restrictions on federal laws relating to navigation to leverage the acquiescence of the mercantile North during the Convention. ${ }^{155}$ It would be a mistake, however, to assume that the Southern states unqualifiedly favored the further importation of African slaves. Southern politicians wanted control over the trade, but they were generally resistant to calls for an unrestricted flood of human chattel. One of the principal reasons for this resistance was their desire to protect a certain form of social stability. "Domestic" slaves-those born and raised on Southern plantations-were acculturated to life in the colonies. Perhaps more importantly, such native born slaves had never lived in freedom, unlike people stolen from the coast of Africa. They were a known quantity and easier to keep under control; hence, they were safer and more valuable. Many Southern whites expressed apprehension at the thought of large numbers of rebel-

154. Section 9 of the Article states that:

The Migration or Importation of such Persons as any of the States now existing shall think proper to admit, shall not be prohibited by the Congress prior to the Year one thousand eight hundred and eight, but a Tax or duty may be imposed on such Importation, not exceeding ten dollars for each Person.

U.S. Const. art. I, $\S 9$, cl. 1 .

155. See Du Bois, supra note 141, at 54-69. Even at the time, the 1808 compromise was a cause of some embarrassment for representatives from the nonslave states, prompting Madison to issue his unconvincing defense in Federalist 42:

It were doubtless to be wished that the power of prohibiting the importation of slaves had not been postponed until the year 1808, or rather that it had been suffered to have immediate operation. But it is not difficult to account either for this restriction on the general government, or for the manner in which the whole clause is expressed. It ought to be considered as a great point gained in favor of humanity that a period of twenty years may terminate forever, within these States, a traffic which has so long and so loudly upbraided the barbarism of modern policy; that within that period it will receive a considerable discouragement from the federal government, and may be totally abolished, by a concurrence of a few States which continue the unnatural traffic in the prohibitory example which has been given by so great a majority of the Union. Happy would it be for the unfortunate Africans if an equal prospect lay before them of being redeemed from the oppressions of their European brethren!

The Federalist No. 42, at 266 (James Madison) (Clinton Rossiter ed., 1961). 
lious African "savages" flowing unrestricted to American shores, and they insisted upon gradualism. ${ }^{156}$ Southern economic interests also favored regulation of the slave trade to protect the value of existing, domestic slave holdings that might be diminished by a glut of human capital on the market. ${ }^{157}$

Thus, the legal slave trade continued during the twenty years following the ratification of the Constitution, but on a regulated basis. Only three of the original slave-holding states officially imported slaves during that time: Georgia, North Carolina, and South Carolina. Even of those, both Georgia and North Carolina voluntarily banned the importation of foreign slaves before the 1808 deadline arrived. ${ }^{158}$ The trade in South Carolina, however, became concomitantly massive. One contemporary Congressional report recorded almost 40,000 slaves imported to Charleston by foreign and domestic traders between 1804 and 1807, the last four years of the legal trade. ${ }^{159}$ Coupled with the ongoing illicit traffic, these numbers were enough to support a significant industry in human importation.

Importantly, this industry was not confined to the slave states of the South. Northern merchants, shippers, and traders played a continuing and vital role in the Southern slave trade. Newport, Rhode Island, in particular, was a major hub for the outfitting of ships engaged in the trade. ${ }^{160}$ Of the 40,000 slaves imported into South Carolina from 1804 to 1807 , about 8,000 were brought on Rhode Island vessels-four times the number that were imported by merchants from Charleston itself. ${ }^{161}$ Indeed, this lucrative trade was the principle source of revenue that enabled Newport to grow into a jewel of affluence. ${ }^{162}$ To a lesser but still

156. Du Bois, supra note 141, at 57.

157. A delegate to the Virginia ratifying convention, for example, lamented the unwillingness of the Southern states to ban the further importation of Africans, in part for fear that such importation would devalue the worth of Virginia holdings: "As much as I value a union of all the states, I would not admit the Southern States into the Union unless they agree to the discontinuance of this disgraceful trade. . . Yet they have not secured us the property of the slaves we have already." Id. at 56 (quoting 3 Jonathan Elliot, The Debates, Resolutions, and Other Proceedings in Convention, 452-53 (Washington, 1830)); see also id. at 56-69 (discussing economic motives of slaveholding states in restricting slave trade).

158. North Carolina imposed a statutory ban upon the further importation of slaves in 1794, and Georgia amended its Constitution to the same effect in 1798. Id. at 71-72.

159. Id. at $90-91 \& 90$ n.5.

160. James A. Rawley, The Transatlantic Slave Trade 359 (1981) ("By all accounts, from contemporary eighteenth-century observers to twentieth-century historians, Rhode Island was North America's foremost slave trading area, with Newport at its center.").

161. Du Bois, supra note 141, at 90-91 n.5; Rawley, supra note 160, at 379-80 (describing magnitude of Rhode Island trade from 1804-1807).

162. Du Bois, supra note 141, at 28; Rawley, supra note 160, at 363-84; Hugh Thomas, The Slave Trade: The Story of the Atlantic Slave Trade: 1440-1870, at 270-72 (1997). 
significant extent, merchants from Massachusetts to Maryland profited handsomely from the trade. ${ }^{163}$

In the years leading up to 1808 , Congress did enact laws that officially outlawed the slave trade, imposing a nationwide ban on both the importation of slaves into the United States from abroad and the participation of American citizens in foreign slave trading activities. ${ }^{164}$ By this time, however, the legal trade in South Carolina and the illicit trade in other slave states had given rise to significant economic interests, in both the North and the South, that were committed to continuing the profitable traffic in African people. Some voices-again, in both the North and the South-condemned the slave trade with high-minded rhetoric, some of it no doubt born of honest moral outrage, and promised to see that the ban was enforced with vigor. ${ }^{165}$ But this rhetoric proved largely empty. For over forty years, federal efforts at enforcement were few and ineffectual. ${ }^{166}$ During this period, the Office of the Treasury, which had responsibility for enforcing the ban, was never given adequate funds for its daunting task and did little to set up procedures or structures to restrict the trade. In 1820, the Treasury Secretary himself reported to the House of Representatives that "It appears, from an examination of the records of this office, that no particular instructions have ever been given, by the Secretary of the Treasury, under the original or supplementary acts prohibiting the introduction of slaves into the United States."167 Thirteen years after the imposition of the federal ban, with the illicit trade continuing to flourish, there was no mechanism in place for enforcing the law and few enforcement actions had been successfully prosecuted. ${ }^{168}$

This lax federal enforcement was joined with widespread and active subterfuge by the slave traders themselves. On the high seas, traders developed an elaborate practice of changing the flags under which their vessels sailed, fraudulently claiming allegiance to different sovereigns in order to protect their ships from being boarded and searched or their cargo seized. ${ }^{169}$ Where necessary, traders would launder their cargo of slaves through markets where the trade remained legal-in the Caribbean, South America, and some European ports—so that the slaves could then be brought to America in small, clandestine shipments. This notori-

163. Du Bois, supra note 141, at 27-29; Rawley, supra note 160, at 385-418; Thomas, supra note 162 , at 271-72, 283-84.

164. Du Bois, supra note 141, at 94-96 (describing first federal law banning slave trade).

165. See, e.g., id. at 102-03 (discussing sentiments expressed by advocates of strict enforcement of slave trade laws).

166. Id. at $109-16$.

167. H.R. Rep. No. 21-348, at 77 (1830).

168. Du Bois, supra note 141 , at 116-17.

169. See, e.g., id. at 146-50 (recounting practices of slave trading vessels). 
ous "triangle trade" maintained an ever increasing flow of slaves from Africa to America. ${ }^{170}$

Domestic participation in this trade was similarly widespread, and took both direct and indirect forms. Northern and Southern vessels alike carried slaves between the ports of Africa or European slave trading nations, the Caribbean, and the South. Shipwrights in both regions learned to specialize in the construction and outfitting of ships for these journeys, while provisioners prepared low quality foodstuffs that could be loaded onto these ships in large quantities. ${ }^{171}$ Such items enabled slave traders to transport massive numbers of kidnapped Africans under extreme conditions while keeping expenses and death rates at profitable levels. ${ }^{172}$ The assistance of such domestic supporting institutions was vital to the continuation of the trade, and the laxity of federal enforcement made that assistance readily available. This state of affairs continued, largely unimproved, through the middle of the century. One New York periodical wrote in 1857 :

Few of our readers are aware ... of the extent to which this infernal traffic is carried on, by vessels clearing from New York, and in close alliance with our legitimate trade; and that downtown merchants of wealth and respectability are extensively engaged in buying and selling African Negroes, and have been, with comparatively little interruption, for an indefinite number of years. ${ }^{173}$

As late as the $1850 \mathrm{~s}$, both on the high seas and domestically, the nationwide ban on the slave trade was honored almost entirely in the breach.

It was only in the period leading up to and following the outbreak of the Civil War that the federal government began serious efforts to enforce the ban on slave trading. The efforts coincided with the increasing polarization of regional interests. Southern slaveholding states began agitating in the 1850s for the formal reopening of the trade, arguing that the ban on importation constituted an assault on the domestic institution of slavery and threatened their economy. ${ }^{174}$ Professor Du Bois explains:

170. Thomas, supra note 162 , at $568-73$.

171. Rawley, supra note 160 , at 254-57, 290-98. Slavers sometimes smoked their ships with pitch, for example, in hopes of slowing the spread of smallpox, and the major slave traders developed specialized medical manuals for the care of slave cargoes. Id. at 291-92, 294-95. They also prepared basic, low quality staples to feed to stolen Africans during the months-long middle passage across the Atlantic. The Slavers (Reindeer), 69 U.S. (2 Wall.) 383, 396-99 (1864); Rawley, supra note 160, at 297-98; see also Thomas, supra note 162, at 304-06 (describing implements of European slave traders).

172. See Rawley, supra note 160, at 283-90 (discussing mortality rates in Atlantic crossing and relationship to profitability of trade).

173. Am. Anti-Slavery Soc'y, 24th Ann. Rep. 56 (1859) (quoting N.Y. J. Com. (1857)).

174. As Professors Foner and Mahoney write, advocates for the reopening of the trade hoped "that an influx of new slaves would increase the number of whites with a vested interest in the institution and lay the groundwork for slavery's expansion southward." Eric Foner \& Olivia Mahoney, A House Divided: America in the Age of Lincoln 68 (1990); see 
When, after 1850 , the price of slaves had risen to a monopoly height, the leaders of the plantation system, brought to the edge of bankruptcy by the crude and reckless farming necessary under a slave régime, and baffled, at least temporarily, in their quest of new rich land to exploit, began instinctively to feel that the only salvation of American slavery lay in the reopening of the African slave-trade. ${ }^{175}$

This radical advocacy produced severe political stresses, both domestically and abroad, ${ }^{176}$ and finally provoked a response from the federal government. In 1859 and 1860, President Buchanan obtained the first substantial appropriations dedicated to enforcement of the ban and placed the weight of his administration behind interdiction efforts. ${ }^{177}$ Abraham Lincoln intensified these efforts and, in 1862, his administration obtained a sentence of death against a convicted slave trader in federal district court, the first capital sentence ever obtained for such a conviction. ${ }^{178}$ With the open declaration of hostilities between the North and the South, the Union demonstrated a new dedication to ending American participation in the slave trade, both domestically and abroad.

It was in this legal and political atmosphere that the Supreme Court decided the Slave Trade Cases. The cases grew out of the federal government's newly vigorous enforcement policy and called upon the Court to define the permissible bounds of such enforcement under existing federal statutes. Decision of this issue, in turn, required the Court to consider the relationship between the actual carrying on of the slave trade itself (through the use of foreign ports) and those supporting institutions that operated domestically to facilitate this trade.

The Slave Trade Cases arose out of seizure and forfeiture proceedings initiated by federal authorities against four ships-the Reindeer, the Kate, the Sarah, and the Weathergage-in U.S. ports of call. The complaint against each ship was that it had been designed and outfitted by its American owner to be used by others in the traffic of human cargo, in violation of the acts of Congress prohibiting American participation in the slave trade. ${ }^{179}$ In none of the cases did federal authorities allege that the ships were used to import slaves into the United States. These were cases involving a traffic in slaves carried on exclusively between foreign ports, as the Court explained in The Reindeer:

[T] he material charges ... [include] the following:

1. That the vessel was . . . fitted, equipped, and prepared

within the port of New York, for the purpose of carrying on

also Du Bois, supra note 141, at 168-78 (describing movement to abolish laws prohibiting slave trade).

175. Du Bois, supra note 141, at 169 .

176. Id. at $146-50$

177. Id. at 187 .

178. Id. at 191.

179. See, e.g., The Slavers (Kate), 69 U.S. (2 Wall.) 350, 363-65 (1864) (describing evidence supporting allegation of participation in slave trade). 
trade or traffic in slaves to some foreign country, or for the purpose of procuring from some foreign kingdom, place or country, the inhabitants thereof to be transported to some foreign country, port or place, to be sold and disposed of as slaves. ${ }^{180}$

Nor did federal authorities allege that the American owners of the ships were themselves slave traders. The offense that merited seizure of these vessels was, as the Court wrote in The Reindeer, that the ships had been "fitted, equipped, and prepared ... for the purpose of carrying on [foreign] trade or traffic in slaves"-in other words, that U.S. intermediaries had taken steps to facilitate a foreign trade in slaves by providing some of the implements best suited to that practice.

There was no question in the mind of the Court that intentional participation by U.S. citizens in a purely foreign slave trade violated the proscriptions laid down by Congress, nor that those proscriptions were legitimate exercises of Congressional power. ${ }^{181}$ Federal law had provided for decades that American citizens were prohibited from participating, either directly or indirectly, in the foreign slave trade. ${ }^{182}$ As the Court had put it in United States $v$. Morris, one of the earlier slave trade prosecutions, "The whole scope of the enactments of congress shows their intention to punish every American citizen who engages in the slave-trade." 183 Elaborating in The Sarah, the Court stated that:

Undoubtedly, the statutory offence is completed when the preparations for the voyage have reached a stage which shows satisfactorily that the purpose of the fitting and equipment was [to facilitate foreign slave trade]. Plainly, the object of the law is to prevent the preparation of vessels in our ports for that trade .... ${ }^{184}$

Similar criminal sanctions for the participation of U.S. citizens in any foreign slave trade continue to exist in the U.S. Code. ${ }^{185}$ Uncontested or

180. The Slavers (Reindeer), 69 U.S. (2 Wall.) 383, 393 (1864).

181. See, e.g., The Slavers (Kate), 69 U.S. (2 Wall.) at 363 ("There is no question of the construction of the acts of Congress, prohibiting the slave-trade, or of the forfeiture, if the allegations of the libel were established by proof.").

182. Thomas, supra note 162, at 568-69 (discussing period of official prohibition). There were at least some prosecutions for such participation during this period of prohibition. In United States v. Morris, for example, the Court affirmed a conviction, writing:

No citizen can fit out or equip a vessel for the slave-trade, either in any part of the United States, or in any other place, to sail from the United States; nor can he hold any property, directly or indirectly, in a vessel engaged in transporting slaves between two foreign countries; nor can a vessel sail from the United States to engage in such traffic; and if she clears out for the coast of Africa, security against her engaging in such traffic may be required, and must be given.

39 U.S. (14 Pet.) 464, 467 (1840).

183. 39 U.S. (14 Pet.) at 467.

184. The Slavers (Sarah), 69 U.S. (2 Wall.) 366, 370-71 (1864).

185. The contemporary proscriptions, contained in Title 18 of the U.S. Code, target the full range of participation by U.S. citizens in any foreign slave trade. Section 1582 forbids the outfitting of ships for use in the slave trade: 
not, however, it is important not to miss the significance of the basic assumption at work in these cases: The indirect facilitation of a purely foreign slave trade by a U.S. citizen through the provision of ships and other equipment is inherently objectionable because it locates a component of that foreign slave trade within domestic borders. That basic assumption, retained in the contemporary federal statutes that prohibit the slave trade, demonstrates a recognition of the interrelation between the institution of slavery and the other institutions that were necessary to perpetuate and support it-a recognition, indeed, that was shared by contemporary defenders of the foreign slave trade, who viewed the trade (and its domestic support structures) as vital to the continued viability of slavery in the South. ${ }^{186}$

To appreciate the significance of that analytical conceit, consider, by way of comparison, the recent attempts in American courts to hold gun manufacturers responsible in tort for the costs resulting from gun-related violence. Modern courts have been quite reluctant to entertain claims that gun manufacturers bear liability for the ultimate criminal use of their products, even though it is commonly understood that their products are widely used in criminal activity, and even though some of the guns that they manufacture are reasonably suited only to criminal purposes-like, for example, the "fingerprint resistant" weapons that gave

Whoever, whether as master, factor, or owner, builds, fits out, equips, loads, or otherwise prepares or sends away any vessel, in any port or place within the United States, or causes such vessel to sail from any such port or place, for the purpose of procuring any person from any foreign kingdom or country to be transported and held, sold, or otherwise disposed of as a slave, or held to service or labor, shall be fined under this title or imprisoned not more than seven years, or both.

18 U.S.C. $\$ 1582$ (1994). Section 1585 prohibits the sale of slaves in foreign slave trade:

Whoever, being a citizen or resident of the United States and a member of the crew or ship's company of any foreign vessel engaged in the slave trade, or whoever, being of the crew or ship's company of any vessel owned in whole or in part, or navigated for, or in behalf of, any citizen of the United States, lands from such vessel, and on any foreign shore seizes any person with intent to make that person a slave, or decoys, or forcibly brings, carries, receives, confines, detains or transports any person as a slave on board such vessel, or, on board such vessel, offers or attempts to sell any such person as a slave, or on the high seas or anywhere on tide water, transfers or delivers to any other vessel any such person with intent to make such person a slave, or lands or delivers on shore from such vessel any person with intent to sell, or having previously sold, such person as a slave, shall be fined under this title or imprisoned not more than seven years, or both.

Id. $§ 1585$. And section 1586 outlaws voluntary participation in foreign slave trade as a member of a ship's crew:

Whoever, being a citizen or resident of the United States, voluntarily serves on board of any vessel employed or made use of in the transportation of slaves from any foreign country or place to another, shall be fined under this title or imprisoned not more than two years, or both.

Id. $\$ 1586$.

186. See supra text accompanying notes 174-176. 
rise to an unsuccessful suit in California. ${ }^{187}$ Where a manufacturer has created a firearm with both legitimate and illegitimate uses, these courts have declined to hold the manufacturer responsible for a purchaser's independent intervening decision to use the gun for illegitimate ends. The defendants in the Slave Trade Cases essentially raised the same defense, arguing that their products—ships, provisions-had many legitimate uses and that they should not be penalized for selling those products in legitimate business transactions. In rejecting these arguments, the Court explicitly marked its recognition of the need for invasive enforcement strategies in the context of the slave trade.

The doctrinal dispute in the Slave Trade Cases centered around the question of evidence. At issue was the level of participation in the foreign slave trade (and evidence thereof) that was necessary to support the drastic remedy of seizure and forfeiture of a valuable vessel and cargo. The pre-War industrialists who supplied foreign slave traders were an ingenious lot. These ship builders and outfitters strove to maintain plausible deniability in their commerce, always selling vessels and goods that were suited to legitimate as well as illicit purposes. The argument of the Assistant U.S. Attorney General in one of the Slave Trade Cases gives some sense (albeit a tendentious one) of the resulting evidentiary obstacles faced by federal authorities in attempting to prevent American participation in this illegal industry:

The [slave] trade, however amenable in reality to the law, is now carried on with a regular machinery to evade law. This is a prerequisite of the trade; an invariable part of it; a machinery which requires lies, fraud, and perjury at the bottom of everything; a machinery of agents and foreigners, regularly prearranged in anticipation of discovery; having no reality for any purpose, and no design but to circumvent justice.

....

In cases of guilt, the following are standing indicia:

....

5. A cargo scrupulously proper for the lawful trade; but with this characteristic of it, that every item of it is equally applicable to the slave-trade, and can easily and instantly be so converted and applied. ${ }^{188}$

At stake in the Slave Trade Cases was the ability of federal authorities to enforce prohibitions on domestic facilitation of the foreign slave trade despite this plausible deniability. Though the ships and cargo supplied to

187. Merrill v. Navegar, Inc., 28 P.3d 116, 119 (Cal. 2001) (construing statute to deny cause of action against gun manufacturer for product liability based on criminal use of gun, even though gun was specially designed to be "fingerprint resistant" and was otherwise suited for criminal uses); see also Hamilton v. Beretta U.S.A. Corp., 75 N.E.2d 1055,1059 (N.Y. 2001) (holding that gun manufacturers owe members of public no duty of reasonable care in marketing and distribution of handguns); id. at 1064-65 n.6 (collecting federal and state cases reaching same result).

188. The Slavers (Kate), 69 U.S. (2 Wall.) 350, 360-61 (1864). 
the slave trade by American industrialists were susceptible of legitimate uses, they exhibited a profile that federal authorities believed that they could identify with confidence and rely upon to initiate forfeiture proceedings. The Reindeer includes a particularly detailed description of such a profile:

Counsel of the United States contend that the vessel was evidently fitted, equipped, and otherwise prepared and caused to sail from the port of New York to Havana, with the ultimate purpose that she should proceed to the west coast of Africa to engage in the slave trade. ...

... They shipped part of the cargo, and the manifest shows that their shipment included one box and twenty-two packages of hardware, and fourteen thousand seven hundred pounds of tasajo, or dried beef, which it is proved comes from Buenos Ayres, and is not an article of shipment from New York to Havana, but is an article imported into Cuba from South America, and is largely used for feeding negroes.

...

... [T] he list of the cargo taken from the vessel, shows that a large quantity of articles, specially suited to the slave trade, were not on the manifest....

Articles not on the manifest embrace sixty-five water-pipes, casks of high-colored paint, pickled fish, coarse salt, two barrels of lime, four jars of chloride of lime, cases of medicines, medicinal herbs and lint, coarse sponges, and one demijohn of disinfecting fluid. ...

All of these articles are proved to be used in the slave trade
. .

Federal authorities sought the ability to obtain orders of forfeiture against owners and suppliers on the basis of such evidence, despite the ever available argument that the industrialists were selling legal goods that could also be put to legitimate use.

The Court granted federal authorities the evidentiary presumption that they sought, ruling in each of the Slave Trade Cases that the circumstances surrounding these putatively legitimate ships and cargoes sufficed to render them subject to forfeiture. ${ }^{190}$ This was an aggressive presumption. In each case, the principal evidence supporting the conclusion that the shipbuilders intended these vessels and cargo to be used in the slave trade (rather than simply knowing or suspecting that they might be) was

189. The Slavers (Reindeer), 69 U.S. (2 Wall.) 383, 396-98 (1864).

190. The Court stated the evidentiary rule most concisely in The Reindeer:

Experience shows that positive proof in such cases is not generally to be expected, and for that reason among others the law allows a resort to circumstances as the means of ascertaining the truth. Circumstances altogether inconclusive, if separately considered, may, by their number and joint operation, especially when corroborated by moral coincidences, be sufficient to constitute conclusive proof. Id. at 401 . 
the suitability of the goods to that ultimate purpose. ${ }^{191}$ To be sure, there was circumstantial evidence to support that conclusion. As discussed above, the role of merchants and shipwrights in supporting the foreign slave trade was well known. But the leap from such circumstantial evidence to a finding that a particular merchant sought to aid and promote the slave trade was a substantial one.

In the lead case in this series, the Court explicitly justified its aggressive evidentiary presumption with reference to the particular evils of the slave trade-evils whose eradication, the Court concluded, could properly require extra sacrifice on the part of international business concerns:

In considering this evidence, it is to be borne in mind, that for more than three hundred years the western coast of Africa has been scourged by the atrocities of the slave-trade; and that this inhuman traffic, although at length proscribed and pursued with severe penalties by nearly all Christian nations, has continued, with almost unabated activity and ferocity, even to our times. . . . It does not seem unreasonable, since it is the paramount interest of humanity that the traffic in men be, at all events, arrested, to require of the trader, who engages in a commerce, which, although not unlawful, is necessarily suspicious from its theatre and circumstances, that he keep his operations so clear and so distinct in their character, as to repel the imputation of prohibited purpose. ${ }^{192}$

Thus, in authorizing federal authorities to target shippers and outfitters directly, the Court recognized the role that such supporting institutions had played in enabling the slave trade to continue and thrive in the face of official condemnation. The disfavored status accorded to the slave trade, the Court concluded, justified extraordinary enforcement mechanisms against those supporting institutions.

This practical experience with the slave trade contributes another element to the multilayered practice of "slavery" that the Thirteenth Amendment must be understood to have eradicated. In the Slave Trade Cases, the Court considered how the slave trade operates on an institutional level-what practices enable the trade to occur and what remedies are necessary to ensure that it "not exist" within a free jurisdiction. The Court concluded that these supporting institutions, in feeding the slave trade and enabling it to function, formed an inextricable and culpable component of the larger practice. It reached these conclusions despite

191. See, e.g., The Slavers (Kate), 69 U.S. (2 Wall.) at 366 (finding guilt based on "the destination of the voyage, the character of the vessel and cargo, and the character and acts of the parties"); The Slavers (Sarah), 69 U.S. (2 Wall.) 366, 374 (1864) ("Considered as a whole, the various circumstances to which reference has been made afford very strong ground of presumption that the allegations of the libel of information are true."); The Slavers (Weathergage), 69 U.S. (2 Wall.) 375, 380 (1864) ("Undoubtedly, it is the preparation of the vessel, and the purpose for which she is to be employed, that constitute the offence, and draw after it the penalty of forfeiture.").

192. The Slavers (Kate), 69 U.S. (2 Wall.) at 363-64. 
the decades during which the federal government permitted the ban to languish unenforced, and despite the significant disruption that this newly aggressive enforcement would work upon domestic financial interests. Any modern analysis of the exploitation of slave labor across national borders must be informed by this experience.

3. Slavery as Industrial Market Force. - The third lens through which I propose to analyze the practice of slavery is the industrial. Where the interpersonal lens focuses attention upon the social relation between master and slave, and the institutional lens scrutinizes the practical operation of a system of slavery, the industrial lens looks to the larger economic forces that give rise to the exploitation of forced labor. In both the justifications offered for slavery by its pre-Civil War defenders and the Supreme Court's subsequent elaborations of the Thirteenth Amendment's mandate, there exists a pervasive recognition that certain industries lend themselves to the exploitation of forced labor and, indeed, create intentional markets for slavery. That recognition forms the basis of my third proposition:

Proposition 3: The Thirteenth Amendment is highly sensitive to the intentional creation of industrial markets for slave labor.

The inhabitants of pre-Civil War America did not understand slave labor to be merely one among many fungible labor options-like different levels of employee training or a forty-five hour work week-that an industry might consider adopting in seeking to maximize its profitability. One of the basic justifications for American slave practices was the notion that certain industries were particularly suited to, and largely dependent upon, the contributions of African slaves. Foremost among these, of course, was the plantation farm industry. As cash-crop operations, these farms required backbreaking work under extreme conditions of temperature and climate and, at the same time, were inherently seasonal, leaving workers with no gainful work for significant portions of the year. Cashcrop plantation farms thus required a workforce of manual laborers who were resilient and industrious (or easily replaceable) and yet would remain tied to the land during the off season. This combination of circumstances rendered slave labor a seductive option.

At the same time, another, complementary notion also permeated the American experience with slavery: the belief that certain industries, in exploiting slave labor, were responding to natural qualities inherent in the enslaved individuals themselves. A special set of justifications for American slavery, deeply inflected with racism, served to explain and reinforce this notion. For example, the defenders of slavery frequently argued that the indigenous peoples of Africa were biologically suited to hard labor in extreme climates, while people of European descent lacked the physical capacity to work effectively under such conditions. Justifications like these offered additional support for the assertion that it was the particular requirements of the industry that both fueled and responded to 
the market for slave labor, and not merely the unwillingness of industrialists to consider other options.

There is no shortage of examples of "scientific" pronouncements on the natural suitability of Africans to the condition of slavery. A typical one comes to us from T.R.R. Cobb, author of an influential nineteenthcentury study of the Southern law of slavery. ${ }^{193}$ As a corollary to his study of legal doctrines, Cobb concluded that Africans were "natural slaves," writing:

This inquiry into the physical, mental, and moral development of the negro race, seems to point them clearly, as peculiarly fitted for a laborious class. Their physical frame is capable of great and long-continued exertion. Their mental capacity renders them incapable of successful self-development, and yet adapts them for the direction of a wiser race. Their moral character renders them happy, peaceful, contented, and cheerful in a status that would break the spirit and destroy the energies of the Caucasian or the native American. ${ }^{194}$

Such sentiments were regularly deployed to justify the morality of keeping people of African descent in bondage. ${ }^{195}$ But they were also used to demonstrate the industrial necessity of that practice-a closely related, but importantly distinct purpose. As defenders of slavery saw it, the "natural suitability" of Africans for the condition of slavery also rendered them an indispensable part of cash-crop plantation farming. If slaves did not do the work, so the argument went, then no one would, and these industries would either cease to function or operate at much lower levels of profit. That being so, the industries themselves created the inexorable demand for slave labor.

Consider in this light the following excerpt from a widely circulated eighteenth-century pamphlet, written by an anonymous English planter in response to Lord Mansfield's ruling in the Somerset case. The author was deeply critical of Somerset, claiming that it would injure the interests of English and American planters, and one of his tasks in this pamphlet was to argue that slavery, though unfortunate, remained a necessary part of agricultural industry:

193. See Paul Finkelman, Thomas R.R. Cobb and the Law of Negro Slavery, 5 Roger Williams U. L. Rev. 75, 100-01, 108-11 (1999) (discussing influence of Cobb's treatise in contemporary discussions of slavery); Tushnet, supra note 97, at 82 (discussing influence of Cobb's treatise among jurists).

194. Thomas R.R. Cobb, An Inquiry Into the Law of Negro Slavery $46-47$ (1858); see also Thomas D. Morris, Southern Slavery and the Law 1619-1860, at 18 (1996) (discussing this passage).

195. Professor Foner describes this belief system in the following terms:

Belief in black inferiority formed a central tenet of the southern defense of slavery, and in the North too, many who were undecided on the merits of the peculiar institution, and even those who disapproved of it, believed that the Negro was by nature destined to occupy a subordinate position in society.

Eric Foner, Politics and Ideology in the Age of the Civil War 77 (1980). 
The nature of the West India climate, and the impossibility of clearing and cultivating the soil there, by any other than Negroe labourers, as it was first the occasion of employing them, so it must ever remain, as long as our colonies exist; because, this natural necessity is not to be cured by any alternative. Some writers have affirmed, that the sugar islands were first cultivated by white men, who shewed no unfitness for labour there, before Negroe-slaves were introduced; but these authors deal in reveries, and seem entirely ignorant both of the subject and the climate they treat upon.

....

Slave-holding might perhaps be very well discontinued in every province of the North American continent, situated to the North of the Carolinas. . . . But in the southern continental province, and in the sugar islands, this practice cannot be laid aside, so long as we persist in the cultivation of them, for the purposes of trade; because, it is impossible to cultivate them with European labourers; and because, the white inhabitants, I presume, can never increase there by propagation in sufficient numbers. ${ }^{196}$

These passages rely upon the same assumptions of racial essentialism that Cobb would reiterate nearly a century later. But here they are deployed, not to justify the continued enslavement of Africans on moral grounds, but to explain the industrial necessity of keeping Africans in bondage. ${ }^{197}$ Such justifications may not have obtained in all commercial settings where slaves came to be employed in America, but they unquestionably constituted one of the dominant narratives of the American slave experience.

Professor Eric Williams, in his landmark study of the economic origins of slavery in the New World, supplements these contemporaneous industrial justifications with an extensive analysis of the demand for labor that the American agricultural economy created. Williams forcefully asserts that plantation farming did not merely create a market for slavery. Given the shortage of European workers, he concludes, the rise of this new, labor intensive industry rendered slavery all but inevitable:

When slavery is adopted, it is not adopted as the choice over free labor; there is no choice at all. The reasons for slavery, wrote Gibbon Wakefield, "are not moral, but economical circumstances; they relate not to vice and virtue, but to production." With the limited population of Europe in the sixteenth century, the free laborers necessary to cultivate the staple crops of sugar,

196. Edward Long, Candid Reflections Upon the Judgement Lately Awarded by The Court of King's Bench, in Westminster-Hall, On What is Commonly Called the NegroeCause 13-14, 18 (1772), reprinted in Slavery and Race, supra note 112, at 83, 99-100, 104.

197. Professor Eric Williams challenges these contemporary, racially inflected explanations for the industrial necessity of slavery, arguing that race was, at best, a post hoc rationalization for what was a simple matter of economics. See infra notes 198-199 and accompanying text.

\section{$\mathbf{R}$}


tobacco and cotton in the New World could not have been supplied in quantities adequate to permit large-scale production. Slavery was necessary for this . . . ${ }^{198}$

Obviously enough, the moral subtext underlying Williams's discussion of the industrial "necessity" of slavery in the New World differs greatly from that of an eighteenth-century apologist. ${ }^{199}$ But the basic observation remains largely the same and is a pervasive one in scholarly discussions of the economics of slavery. ${ }^{200}$ Deeply embedded in both preCivil War conceptions of slavery and in subsequent scholarly analyses was the understanding that the particular economies of the New World had created industrial markets for slave labor. ${ }^{201}$

198. Eric Williams, Capitalism \& Slavery 6 (2d ed. 1994) (quoting Edward Gibbon Wakefield, A View of the Art of Colonization 323 (London, J.W. Parker 1849)).

199. Of necessity, I am glossing over much complexity here. As Williams explains at length, the European expansion into the New World gave rise to a tension among 1) scholarly tenets (most notably those of Adam Smith) that largely rejected slavery as an economically attractive option, 2) the reality of labor shortages and the resulting exploitation of slave labor, and 3) disingenuous attempts to justify that reality in terms of natural racial hierarchy rather than economic self-interest. Williams, supra note 198, at 3-9. But determining the proper resolution to that tension is not germane for present purposes, for it is a tension over explaining a generally accepted fact-the driving force of industrial necessity in creating markets for slave labor.

200. See, for example, Du Bois in his treatise on the slave trade:

The planting colonies are those Southern settlements whose climate and character destined them to be the chief theatre of North American slavery. . . . Theirs was the only soil, climate, and society suited to slavery; in the other colonies, with few exceptions, the institution was by these same factors doomed from the beginning. Hence, only strong moral and political motives could in the planting colonies overthrow or check a traffic so favored by the mother country. Du Bois, supra note 141, at 7.

201. It should be noted that the economic rationality of slave labor, particularly in the Deep South, was much debated in the nineteenth century and remains much debated today. See, e.g., Robert William Fogel \& Stanley L. Engerman, Time on the Cross 4-6 (1974) (describing debate between received view of slavery's economic irrationality and more recent scholarship criticizing that view). While industries like plantation cash-crop farming created the demand for slave labor, it is far from clear that the satisfaction of that demand redounded to the ultimate economic benefit of the owners. An opinion of the Virginia Court of Appeals, rejecting a claim for unpaid wages by slaves who successfully sued for their freedom, captures the tenor of the debate:

The arrangements, management and expenditures of slave owners are, in a great measure, essentially different from those of persons who employ free labour in their occupations and service. The latter are, for the most part, in the habit of engaging individuals, from time to time, as the occasion may seem to require, and of dismissing them when found unsuitable or unnecessary; and are in no wise bound to provide gratuitously for their wants and comforts, or the maintenance of their families. The owner of slaves, on the contrary, is usually condemned to a constant, permanent and anxious burthen of care and expenditure. It seldom happens that more than a small proportion of them are capable of productive labor; while provision must be made for the food, clothing and shelter of all; for the helplessness of infancy, the decrepitude of age, the infirmities of disease; to say nothing of the heedlessness, slothfulness and waste natural to persons in their condition. Hence it is that the scantiness of net profit from slave labour has 
One of the post-Civil War peonage cases discussed earlier, ${ }^{202}$ Pollock v. Williams, ${ }^{203}$ illustrates the extent to which this understanding has continued to inform the Court's engagement with slavery claims under the Thirteenth Amendment. Pollock was the last in the series of opinions, beginning with Clyatt $v$. United States ${ }^{204}$ and Bailey v. Alabama, ${ }^{205}$ in which the Court took progressively tougher positions on the practice of peonage in America. The early peonage opinions-ruling, as they did, on statutes that were largely unabashed in their support of peonage arrangements-offered possible grounds for distinguishing later, more sanitized tactics, and some states repeatedly amended their statutes in an attempt to find a peonage scheme that would pass muster. ${ }^{206}$ In Pollock, the Court issued what it clearly intended to be (and in fact was) its final statement on the subject of peonage, putting to rest further attempts at formal circumvention. ${ }^{207}$

The Pollock Court set forth the broad and unequivocal holding that "no state can make the quitting of work any component of a crime, or make criminal sanctions available for holding unwilling persons to labor." 208 In so doing, it discussed the practice of peonage in a manner that revealed a continuing sensitivity to the potential for particular industries to embrace slave practices, citing approvingly and quoting at length

become proverbial, and that nothing is more common than an actual loss, or a benefit merely in the slow increase of capital from propagation.

Peter v. Hargrave, 46 Va. (5 Gratt.) 12, 19 (1848); see also Tushnet, supra note 97, at 22-23 (discussing Hargrave).

202. See supra note 50 .

203. 322 U.S. 4 (1944).

204. 197 U.S. 207 (1905).

205. 219 U.S. 219 (1911).

206. See Clyatt, 197 U.S. at 216 (holding that Thirteenth Amendment prohibits peonage arrangements); Bailey, 219 U.S. at 238-39 (extending Clyatt to "antifraud" statutes where black workers, who were not allowed to testify, were convicted based on statutory "presumptions"); Taylor v. Georgia, 315 U.S. 25, 29-31 (1942) (extending Bailey to situations where accused workers are allowed to make unsworn statements in their defense); Pollock, 322 U.S. at 22-25 (extending Bailey to situations where accused workers are allowed to offer sworn testimony in their defense); id. at 15-17 (detailing attempts by Florida to reenact peonage schemes in response to successful Thirteenth Amendment challenges).

207. The Court did not mince words. Consider, for example, this rather blunt preface to the section of the Court's opinion addressing the purposes underlying the Thirteenth Amendment and their application to the practice of peonage: "We are induced by the evident misunderstanding of our decisions by the Florida Supreme Court, in what we are convinced was a conscientious and painstaking study of them, to make more explicit the basis of constitutional invalidity of this type of statute." Pollock, 322 U.S. at 17.

208. Id. at 18. As in most of the peonage cases, the petitioner in Pollock made claims under both the Thirteenth Amendment itself and the federal antipeonage provisions that implement the Amendment, and the Court's discussion of the two is largely interchangeable. See, e.g., id. at 17-18 ("The undoubted aim of the Thirteenth Amendment as implemented by the Antipeonage Act was not merely to end slavery but to maintain a system of completely free and voluntary labor."). 
\begin{tabular}{lllll}
\hline \Server03\productn\CCOL $\backslash 102-4 \backslash$ COL403.txt & unknown & Seq: 54 & 7-MAY-02 & 17:50 \\
\hline
\end{tabular}

from a congressional report on the subject. Speaking first to the incidence of peonage as a general matter, the Court wrote:

Where peonage has existed in the United States it has done so chiefly by virtue of laws like the [antifraud] statute in question. ... In 1910, in response to a resolution of the House of Representatives, the Immigration Commission reported the results of an investigation of peonage among immigrants in the United States. It found that no general system of peonage existed, and that sentiment did not support it anywhere. On the other hand, it found sporadic cases of probable peonage in every state in the Union except Oklahoma and Connecticut. ${ }^{209}$

These "sporadic cases" usually centered around industries that were dependent upon an immigrant workforce, as the Court explained in discussing one of the most extreme examples documented in the congressional report:

[The report] pointed out that "there has probably existed in Maine the most complete system of peonage in the entire country," in the lumber camps. . . . "In late years the natives who formerly supplied the labor for the logging concerns in that State have been engaged in the paper mills, and the lumber companies have been compelled to import laborers, largely foreigners, from other States. Boston is the chief labor market for the Maine forests. The employment agents misrepresent conditions in the woods .... The men will then be kept in the heart of the forest for months throughout the winter, living in a most rugged fashion and with no recreation whatever."210

The report continues, explaining how quickly and thoroughly this system of involuntary servitude became intertwined with the lumber industry in the region:

Involuntary servitude results in utilizing this statute to intimidate laborers to work against their will. On account of the vigorous methods pursued in enforcing the above-described law, it soon became known throughout the lumber region of Maine that any laborer was liable to imprisonment who refused to work according to the provisions of his contract until he had settled for all advances, no matter what misrepresentations may have been made to induce him to enter into the agreement. The contract-labor law has become a club which the foremen and superintendents draw upon the laborers who refuse to go to work or to continue at work. If a man leaves his employer before settling for advances, he will be pursued and apprehended, or someone will telephone to the constable, who will arrest the laborer. He will then be brought before the justice, and "sent down the river," to prison; or if he consents to labor

209. Id. at 18.

210. Id. at 18-19 \& 19 n.30 (quoting 2 Report on Peonage, Abstracts of Reports of the Immigration Comm'n 447, Sen. Doc. No. 747, 61st Cong., 3d Sess.) [hereinafter Report on Peonage]. 
until he shall have reimbursed for all advances and the fine and cost of the prosecution, the employer will settle with the court and constable and will take the laborer back into the forest. ${ }^{211}$

The actual dispute in Pollock did not concern peonage in Maine at all; strictly speaking, the Court's extended discussion of the Maine lumber industry was unnecessary to its holding. ${ }^{212}$ Rather, the Court's apparent purpose in describing the Maine situation at such length was to offer an exemplar of the system of peonage that it meant finally to eradicate with its broadly written opinion. Its choice of subject is revealing. The characteristics of the peonage system in the Maine lumber industry bore some disturbing similarities to the slavery that existed on Southern cashcrop plantations: a racially defined, captive workforce, tied by economic vulnerability and physical coercion to an industrial harvesting business, and kept on the job through the active cooperation of legal authorities. Certainly, the congressional report's reference to laborers being "sold down the river" to prison when they attempted to leave their jobs was intended to evoke this parallel. As Professor Jones makes clear, the pattern identified by the Court in Pollock was pervasive. Jones has documented instances of peonage around the South at the turn of the century. ${ }^{213}$ Most operated much like the abuses in the Maine lumber industry:

The more remote a camp, the bleaker the existence of the people who lived in it, the more desperate their desire to leave, and the more difficult their escape from its confines. Time and again federal authorities investigating peonage cases cited the inaccessibility of the work site as a major element in both hiding abuses and preventing their eradication. ${ }^{214}$

Having set forth its practical understanding of the capacity of certain industries to generate a demand for forced labor, the Pollock Court goes on to tie that understanding to some of America's earliest insights about the cascading impacts of slavery. In a deep recapitulation of the treatment of the slave arrangement as a pernicious social relation, so pervasive in pre-War slavery jurisprudence, the Court explains that slave exploitation by one employer can also have a pernicious impact upon free labor within an entire industry:

When the master can compel and the laborer cannot escape the obligation to go on, there is no power below to redress and no incentive above to relieve a harsh overlordship or un-

211. Id. at 20-21 n.32 (quoting Report on Peonage, supra note 210, at 448-49).

212. The actual holding of Pollock simply extended the proscription against "antifraud" peonage statutes to include cases (like the one under the Florida prosecution before it) where accused workers were allowed to offer sworn testimony in their own defense. Id. at 25.

213. Jones, supra note 32 , at 73-166.

214. Id. at 153; see also id. at 128 (discussing peonage in Florida phosphate industry); id. at 152 (discussing peonage in turpentine industry); Goluboff, supra note 21, at 1657-58 (describing exploitation of forced labor in Florida).

$\mathbf{R}$ 
wholesome conditions of work. Resulting depression of working conditions and living standards affects not only the laborer under the system, but every other with whom his labor comes in competition. ${ }^{215}$

Here we see the hard fought lesson of the American experience with slavery as a social relation projected onto a broader screen. As the social relation of slavery endangers the morals of the master, inspiring in him "the most boisterous passions, the most unremitting despotism," 216 so the resulting "depression of working conditions and living standards" in the laborer "affects . . . every other with whom his labor comes in competition." Indeed, these insights echo the expressions of concern issued by members of Congress during the ratifying debates for the Thirteenth Amendment that the presence of slavery in an industry "degrades labor" and harms the lot of free workers. ${ }^{217}$ Pollock thus completes the translation of the Thirteenth Amendment, begun in Clyatt and Bailey, that was necessary to accommodate the changing forms of labor exploitation in the first half of the twentieth century. ${ }^{218}$

This was not the first time that the Court had revealed a sensitivity to the possibility that particular industries might recreate the forms of American slavery under a different name. As early as the Slaughter-House Cases 219 - one of the first expositions of the Thirteenth Amendment's substantive content-the Court made it clear that this possibility loomed large in its analysis. There, the Court explained the Amendment's prohibition of "involuntary servitude" in the following terms:

It was very well understood that in the form of apprenticeship for long terms, as it had been practiced in the West India Islands, on [the occasion of] the abolition of slavery by the English government, or by reducing the slaves to the condition of

215. Pollock, 322 U.S. at 18.

216. Jefferson, supra note 116, at 403.

217. VanderVelde, supra note 38 , at $470-73$ \& n.150; supra text accompanying notes $136-138$.

218. Professor Goluboff finds similar transformative significance in Pollock, albeit with a more domestic focus. As she explains, federal enforcement authorities (under the leadership of Attorney General Biddle) viewed Pollock as a long overdue endorsement of a broader, more liberatory enforcement of workers' rights in America: "In light of [the above quoted statements], Biddle interpreted Pollock and the other 1940s peonage cases as including within the mid-twentieth century meaning of involuntary servitude the creation of a national, unitary labor market unimpeded by state and local legal obstacles." Goluboff, supra note 21, at 1675; see also id. at 1660 ("The 'realities' of involuntary servitude, which the turn-of-the-century Supreme Court had been unwilling to acknowledge in its attention to contract, began to constitute its meaning and popular usage in the 1940s."); id. at 1656 ("Biddle . . . indicated that prohibiting involuntary servitude meant far more than eliminating the direct coercion of a particular employer upon a particular employee. It meant the creation and protection of a unitary, national labor market.").

219. 82 U.S. 36 (1872). 
serfs attached to the plantation, the purpose of the article might have been evaded, if only the word slavery had been used. ${ }^{220}$

The Court's references to the West Indies and plantation farming in this explanation are more than incidental. The inclusion of "involuntary servitude" in the Amendment, the Court explains, was meant to reach those arrangements (like peonage) that exhibited "that control by which the personal service of one man is disposed of or coerced for another's benefit" 221 but lacked other characteristics (property rights, corruption of blood) that marked the American system of slavery. Plantation farming, the Amendment's drafters understood, possessed a tenacious capacity to create markets for the exploitation of involuntary labor, even following the eradication of chattel slavery, and they included involuntary servitude in the Amendment's language in anticipation of such industry driven efforts.

America's experience in the years following emancipation-an experience characterized by the country's failure in many respects to implement the principles that it had inscribed into the Constitution-served to reinforce this lesson. The country emerged from the Civil War with an economy that remained largely dependent upon the exploitation of subjugated workers. ${ }^{222}$ While the fiat of the Thirteenth Amendment could effect radical changes in the legal status of American laborers, it could not do the same for the structure of the American economy. This was one of the signature dilemmas of Reconstruction: the sudden disjuncture between the labor needs of American industry as it then existed and the acceptable methods of fulfilling those needs. ${ }^{223}$ Professor Gerald Jaynes, in his important economic analysis of the post-War South, poses the problem in the following terms: "[I]rrespective of one's philosophical orientation, any attempt to understand American Reconstruction must face this central issue: after the abolition of slavery, how was an industrial order dedicated to commercial production of agricultural products for a market system to be maintained?" 224 In declining to provide most of the freed slaves with homesteads or any other form of reparations, Congress compounded the problem, rendering profoundly vul-

220. Id. at 69.

221. Bailey v. Alabama, 219 U.S. 219, 241 (1911).

222. The roots of this dependency ran deep. Professor Genovese has described, as one of slavery's "many paradoxes," that "the dominant rural slaveholders required some industrial expansion to support their plantation economy and political power but could not sustain economically or tolerate politically a general industrialization." Eugene D. Genovese, The Political Economy of Slavery 181 (3d ed. 1965)

223. As one commentator observed as late as 1936: "Slavery was too integral a part of the social life of the South and too vital to the interests of certain classes to be suddenly eliminated by a mere constitutional amendment, although the amendment did make necessary the finding of new ways of perpetuating the Negro's enslavement." Goluboff, supra note 21, at 1679-80 (quoting Slavery Seventy Years After, 53 Christian Century 1645 (1936)).

224. Gerald David Jaynes, Branches Without Roots: Genesis of the Black Working Class in the American South, 1862-1882, at 5 (1986). 
nerable the very population of workers who would be the object of industrial attempts to recreate the economic realities of slavery. In this respect, as in others, principle bowed to the perceived self-interest of powerful economic forces during Reconstruction. ${ }^{225}$ Contemporary lawmakers were not unaware of the problem. To cite one example among many, Thaddeus Stevens, one of the leading radicals in the Reconstruction Congress, forcefully upbraided his peers for their failure to couple emancipation with economic reform:

We have turned, or are about to turn, loose four million slaves without a hut to shelter them or a cent in their pockets. The infernal laws of slavery have prevented them from acquiring an education, understanding the commonest laws of contract, or of managing the ordinary business of life. This Congress is bound to provide for them until they can take care of themselves. If we do not furnish them with homesteads, and hedge them around with protective laws; if we leave them to the legislation of their late masters, we had better have left them in bondage. ${ }^{226}$

Yet warnings like Stevens's went unheeded, and Congress established an anemic Freedmen's Bureau and made no provisions for reparations. ${ }^{227}$ An exploitative sharecropping system and arrangements of outright peonage arose as a matter of course. ${ }^{228}$

The Slaughter-House Cases and Pollock come to us against the backdrop of this experience. The two cases are, in some sense, the warp and woof of the Court's first translation of the Thirteenth Amendment into a new industrial context: the Slaughter-House Cases providing an early statement of principles that went largely unrealized for many years; Pollock finally applying those principles in a definitive manner to the new patterns of forced labor that had emerged to replace the old. Together, the discussions of labor and industry contained in the two cases set forth some of the essential vocabulary of the Thirteenth Amendment and its attitude toward the incorporation of forced labor in American industry. Such statements may be more atmospheric than analytical. But atmospherics are important in the interpretation of an amendment whose broad mandate "absolute[ly] declar[es] that slavery or involuntary servitude shall not exist in any part of the United States."229 One pervasive element of the atmosphere that surrounds the constitutional prohibition

225. See id. at $16-53$.

226. Id. at 19 (quoting Thaddeus Stevens, "Reconstruction," December 18, 1865, in Congress, in 2 Selected Papers of Thaddeus Stevens 44, 52 (Beverly Wilson Palmer ed., 1998)).

227. As Professor Foner has explained, the Freedmen's Bureau suffered from a serious lack of funding, an overambitious mandate, and a misguided belief that the economic interests of freed slaves and former slaveholders could be brought into harmony. Eric Foner, Reconstruction: America's Unfinished Revolution 1863-1877, at 142-44, 169-70 (1988).

228. See Jaynes, supra note 224, at 24-53 (discussing conditions that gave rise to sharecropping); Jones, supra note 32, at 73-166 (discussing peonage arrangements). 
against slavery is an acknowledgment that particular industries can readily lend themselves to the exploitation of slavery and, in some cases, intentionally create new markets for forced labor. Indeed, in the case of Pollock, that acknowledgment came at a time when concerns over the exploitation of forced labor by foreign totalitarian regimes were acute. ${ }^{230}$ Coupled with that acknowledgment was a heightened attention to those industrial arrangements that resurrect elements of the old American slave system and attempt to reestablish them in a new industrial context.

\section{B. Toward a Modern Jurisprudence of Slavery}

1. Doctrinal Tools. - What, then, is accomplished in establishing these three propositions? Most importantly, they call upon us to remember that "slavery," as that term is used in the Thirteenth Amendment, does not simply describe the physical presence of individuals being forced to labor against their will. When the Amendment pronounces that "slavery ... shall [not] exist within the United States," that pronouncement necessarily operates on many levels. It is founded first on the understanding that slavery creates a pernicious interpersonal relationship that is injurious to owner and slave alike, working a "corruption of manners in the master, from the entire subjection of the slaves he possesses to his sole will." ${ }^{331}$ In abolishing slavery, the Amendment necessarily abolished the entire social relation of master and slave, for the dominion that an overseer exercises over a forced laborer is an evil that attaches to both individuals. Under the Thirteenth Amendment, neither slaves nor masters may exist on domestic soil.

The Amendment's mandate is also informed by a history of practical experience with the supporting institutions of slavery-those that permitted domestic slavery to function and those that were targeted for prosecu-

Professor VanderVelde has made a similar observation in discussing the ratification debates for the Thirteenth Amendment:

The debates do not fix a single, static meaning for the amendment or the concept of free labor. Instead, they establish parameters within which many interpretations are possible. The resulting boundaries of meaning fence out certain relationships as beyond the scope of the amendment. They encompass a vast array of possible interpretations emanating from the statements of the framers' core values and objectives. And finally, the debates mark certain customs and actions as evils to be proscribed.

VanderVelde, supra note 38, at 452.

230. See Goluboff, supra note 21, at 1621 (“"[T] he revival of slavery on a large scale by the totalitarian regimes in the new form of slave labor camps for ethnic and political "unregenerates" has shaken [the] comfortable thought' that 'slavery and involuntary servitude [were] evils which were wiped out in the Nineteenth Century." (quoting Howard Devon Hamilton, The Legislative and Judicial History of the Thirteenth Amendment: What Is Not Involuntary Servitude, 10 Nat'l B.J., March 1952, at 7, 77)); cf. West Virginia State Bd. of Educ. v. Barnette, 319 U.S. 624, 641-42 (1943) (articulating American free speech principles in contradistinction to "our present totalitarian enemies").

231. Somerset v. Stewart, 98 Eng. Rep. 499, 500 (K.B. 1772). 
tion as a component of the forbidden slave trade. That experience with slavery's supporting institutions in turn contributes an element to the change that the Amendment has effected in the nature of the social and economic relationships that can exist within the United States. As in the Slave Trade Cases before it, the Amendment raises a presumption against those domestic commercial ventures that participate intimately in the deliberate exploitation of foreign slaves. It requires, to quote one of the Court's 1864 opinions, that when a U.S. multinational corporation "engages in a commerce, which, although not unlawful, is necessarily suspicious from its theatre and circumstances, that [it] keep [its] operations so clear and so distinct in their character, as to repel the imputation of prohibited purpose." 232

And the Amendment carries with it a high degree of sensitivity to the capacity of particular industries, through the incorporation of slave labor into their operations, to create a self-justifying and self-perpetuating market for human bondage. Thus, when an industry lends itself to the exploitation of indigenous populations for reasons of geography or climate, or when the economies of production in a poor or remote community create powerful incentives to enslave workers in a local population-as in the peonage arrangements of the Maine timber industry discussed in Pollock ${ }^{233}$ — these circumstances are not merely incidental to a Thirteenth Amendment analysis. Rather, they implicate one of the Amendment's central concerns. Any analysis of forced labor in a new industrial context must afford a privileged place to that concern, as the Court did in prohibiting the emerging peonage schemes of the early twentieth century.

These are not mere statements of abstract principle. They are doctrinal tools-the same tools that pre-Civil War courts in free jurisdictions employed in combating the domestic institution of slavery while it was still alive, and that the post-Civil War Supreme Court employed in concluding that putatively "voluntary" peonage schemes could not survive Thirteenth Amendment scrutiny. These same doctrinal tools likewise govern claims of the exploitation of foreign labor by U.S. entities in multinational transactions. By way of example, let us return to three of the instances of forced labor described in Part I: Burma, Saipan, and Ivory Coast.

The strongest case for a foreign slave labor claim would seem to arise where a U.S. entity deliberately subjects foreign workers to a condition of slavery or involuntary servitude through direct participation. The situation in Burma may fit this description. Assuming, for present purposes, that the facts alleged by the plaintiffs in Unocal are true, Unocal has engaged in activities that implicate all three of the principles described above. First, it entered into a commercial venture with full knowledge that indigenous laborers would be pressed into involuntary service on an

232. The Slavers (Kate), 69 U.S. (2 Wall.) 350, 364 (1864).

233. See supra notes 210-212 and accompanying text. 
ongoing basis. ${ }^{234}$ These conditions of forced labor are episodic in nature-the indigenous population has been subjugated as a direct response to the industrial needs of the Unocal joint venture and the project that they have undertaken. The Yadana and Yetagun projects have thus assumed the role of the Maine lumber industry and Southern plantation farms before them, creating an inexorable demand for local, forced labor. In this light, Dick Cheney's assertion for Halliburton- "The problem is that the good Lord didn't see fit to always put oil and gas resources where there are democratic governments" 235 - is revealed as a modern analogue to the ubiquitous pre-Civil War rationalizations claiming that domestic slavery was necessitated by exigencies of geography, economics, or essential characteristics of race. ${ }^{236}$

It is further alleged that Unocal has itself participated in the exploitation of these indigenous laborers, instructing its agents and employees in how to dispose of their forced efforts. It has given directions as to where the laborers should clear land to lay pipe, where and when they should build helicopter pads, and when they are needed as porters for executive bodyguards. ${ }^{237}$ In so doing, Unocal has initiated a social relation of dominance between itself (through its agents and employees) and the indigenous Burmese workers-a relation characterized further by that particular quality of disposability that Professor Bales has identified as characteristic of many modern slave relationships ${ }^{238}$ and that tainted the American system of peonage. Under Bailey v. Alabama, American industry is not "free" when it exhibits "that control by which the personal service of one man is disposed of or coerced for another's benefit which is the essence of involuntary servitude." 239

Finally, through its participation in these foreign labor practices, Unocal has transformed a part of its U.S. operations into a supporting institution for forced labor. The U.S. company is providing the resources and, in some cases, the personnel and instrumentalities for the enslavement of the foreign workers-from food and provisions for the laborers and their military overseers to shelter and transportation along the pipeline route. This transformation recalls the role of the U.S. provisioners in the Slave Trade Cases, facilitating the kidnapping and enslavement of foreign workers by providing the instrumentalities for their exploitation. ${ }^{240}$ That participation, though indirect, prompted the Supreme Court to require that U.S. businesses that "engage[] in a commerce, which, although not unlawful, is necessarily suspicious from its theatre and cir-

234. Doe v. Unocal Corp., 963 F. Supp. 880, 884-85 (C.D. Cal. 1997).

235. Waldman, supra note 69. See supra text accompanying notes 68-70.

236. See supra Part II.A.3.

237. Unocal, 963 F. Supp. at 885; Total Denial Continues, supra note 57, at 62-99.

238. Bales, supra note 52, at 4; see also Total Denial Continues, supra note 57, at 23-25 (describing rotation of Burmese villagers through forced labor camps).

239. 219 U.S. 219, 241 (1911).

240. See supra Part II.A.2. 
cumstances, ... keep [their] operation[ ] so clear and so distinct in their character, as to repel the imputation of prohibited purpose." ${ }^{241}$

If the allegations against it are true, then Unocal's participation in the Burma project makes out a strong case for a Thirteenth Amendment violation. One can naturally expect the knowledge and complicity of U.S. businesses in the use of foreign slave labor to be contested in such cases. ${ }^{242}$ In this regard, however, it bears remembering that the Supreme Court expressed contempt for the protestations of the industrial petitioners in the Slave Trade Cases that they were ignorant of the true nature of the business they were supporting and so lacked direct responsibility. ${ }^{243}$

Similar arguments apply to sweatshop cases like the one in Saipan. If the allegations in those cases are true, then, as in Burma, the agents of U.S. clothing manufacturers in Saipan have initiated a relationship of dominance at the direction of the U.S. entities, subjecting their workers (many of whom were imported from poor Asian countries) to conditions of forced labor on threat of violence or legal sanction. ${ }^{244}$ The U.S. entities, in setting up the sweatshops and hiring the personnel that would be used to enslave the migrant workers, have transformed a portion of their U.S. operations into supporting institutions for that slave system. And, in so doing, these U.S. entities have created markets for involuntary labor that had not previously existed, resulting in many workers being lured from their home countries under false pretenses and pressed into service upon reaching Saipan. When such conditions arise outside of American territorial possessions (as experience suggests that they will), it appears that sweatshop cases including allegations of this level of U.S. participation will also make out a strong Thirteenth Amendment claim.

The Thirteenth Amendment argument is weaker where the burden of the claim is that a U.S. entity is knowingly making use of the fruits of a slave system that it had no role in creating. The recent experience with cocoa plantations in Ivory Coast provides a good example. Thus far, there are no allegations that U.S. entities have played any role in initiating or directing the exploitation of slave labor on the plantations. That being so, the social relation of dominance appears to be absent-U.S. entities and their agents play no direct role in the disposition of the involuntary laborers. Moreover, the only tool or instrumentality of the foreign slave system that U.S. entities appear to be supplying in such a case is the

241. The Slavers (Kate), 69 U.S. (2 Wall.) 350, 364 (1864).

242. Unocal recently won summary judgment on the Alien Tort Claims Act claims, successfully arguing that the Burmese plaintiffs had not adduced sufficient evidence to raise a triable issue on Unocal's intentional exploitation of local workers. Doe v. Unocal Corp., 110 F. Supp. 2d 1294, 1296 (C.D. Cal. 2000). At the writing of this Article, that ruling is on appeal to the Ninth Circuit.

243. See, e.g., The Slavers (Kate), 69 U.S. (2 Wall.) at 366 ("The case presents none of the marks of an honest transaction, but bears upon it such indications of the guilty purpose to employ the bark in the slave-trade, that we should require clear explanation by convincing proof to repel the conclusion that such was her destined employment.").

244. See supra text accompanying notes 76-79. 
money that they pay for the goods produced by forced labor. While it is undoubtedly the case that such money ultimately contributes to the subjugation of more forced laborers, this is an attenuated connection. The strongest argument in the cocoa bean case would seem to arise if it could be shown that U.S. entities constituted most or all of the market for the product of the foreign slave labor-if, in other words, it could legitimately be said that U.S. entities were creating the market for slave labor through their purchase of these foreign goods. This probably is not so in the case of cocoa beans-the U.S. is not the only consumer of Ivory Coast's production. ${ }^{245}$

And even if U.S. entities, through their purchase of a particular good, were solely responsible for the creation of a foreign market in slave labor, this would seem, without more, to be a weak case. Recognizing a Thirteenth Amendment claim in such a case would essentially amount to the imposition of a general embargo upon exclusive trading arrangements with nations that exhibit serious problems with forced labor. There seems little basis for interpreting the Thirteenth Amendment so totally to preempt the traditional authority of Congress and the President to conduct America's foreign trade policy. ${ }^{246}$ While there might be a moral imperative for U.S. chocolate producers to avoid supporting the exploitation of forced labor through their purchases of raw materials, the Thirteenth Amendment probably does not mandate this result.

2. Substantive Objections. - One can imagine a number of substantive objections to these types of Thirteenth Amendment claims. First, the factual issues in a foreign slave labor case will often be quite complex, owing in no small part to the involvement of foreign jurisdictions. Logistically, the sources of evidence in such a case are likely to span continents, being located both in the domestic offices of U.S. entities and in the jurisdiction where their employees or agents, and the forced laborers, are physically located.

But the added complexity that might attend some foreign slave labor cases does not call into question the propriety of recognizing the claims. U.S. antitrust laws have been applied to international disputes for decades now, often in cases of great complexity that require a court to assess market conditions in one or more foreign jurisdictions, and courts have learned to address these claims. ${ }^{247}$ More broadly, the complexities attendant to a foreign slavery case are liable to be present in any case seeking to enforce international human rights principles. Since the Second

245. See America's Sweets, supra note 86, at 1-2.

246. Cf. Crosby v. Nat'l Foreign Trade Council, 530 U.S. 363, 372-86 (2000) (discussing presumptive role of Congress and President in conducting foreign relations).

247. See, e.g., In re Ins. Antitrust Litig., 723 F. Supp. 464, 468-72 (N.D. Cal. 1989) (detailing antitrust claims involving international insurance interests), rev'd, 938 F.2d 919 (9th Cir. 1991), aff'd in part and rev'd in part sub nom. Hartford Fire Ins. Co. v. California, 509 U.S. 764 (1993). 
Circuit's decision in Filartiga v. Pena-Irala, ${ }^{248}$ claimants have increasingly used the Alien Tort Claims Act ${ }^{249}$ to raise claims alleging violations of international law against both foreign and domestic entities (including Unocal) in U.S. courts. ${ }^{250}$ In short, the objection that such cases are too complex or difficult to adjudicate in American courts is one that we have already moved past in the spheres of both commerce and human rights.

A more serious objection might arise in cases where the foreign slave labor follows a putative criminal conviction. The Thirteenth Amendment makes an explicit exception in its mandate for those whose labor is "a punishment for crime whereof the party shall have been duly convicted." ${ }^{551}$ That exception would presumptively apply with equal force to a claim under the Thirteenth Amendment based upon foreign slave practices. This might raise difficult issues in cases where the criminal justice system of another country employs standards that would not be acceptable under our Constitution. In China, for example, there is a widespread practice of forced labor in "Laogai"-labor camps to which individuals are sent following prosecution for criminal offenses. ${ }^{252}$ If a U.S. corporation began using labor in Laogai camps, a Thirteenth Amendment claim seeking to enjoin the practice would meet with the objection that the workers had been "duly convicted" of a crime and hence were outside the Amendment's reach. China's standards of due process and the rights of criminal defendants fall far short of our own. ${ }^{253}$ In the civil context, there are provisions in American conflicts law for a U.S. court to

248. 630 F.2d 876, 887 (2d Cir. 1980) (holding that Alien Tort Claims Act provides cause of action under which foreign nationals can enforce violations of international law). See also Ryan Goodman \& Derek P. Jinks, Filartiga's Firm Footing: International Human Rights and Federal Common Law, 66 Fordham L. Rev. 463, 464-66, 480-93 (1997) (discussing foundations for Filartiga decision).

249. 28 U.S.C. $\$ 1350$ (1994).

250. See, e.g., Kadic v. Karadžić, 70 F.3d 232, 242 (2d Cir. 1995) (recognizing genocidal campaign of organized violence as basis for ATCA claim in case arising from Bosnian conflict); Iwanowa v. Ford Motor Co., 67 F. Supp. 2d 424, 446, 490-91 (D.N.J. 1999) (recognizing, in principle, ATCA claims against Ford Motor Company concerning role in Nazi war crimes, but dismissing on grounds of treaty foreclosure and statute of limitations); Doe v. Unocal Corp., 963 F. Supp. 880, 891-92 (C.D. Cal. 1997) (recognizing forced labor in Burma as basis for ATCA claim).

251. U.S. Const. amend. XIII, § 1 .

252. U.S. Implementation of Prison Labor Agreements with China: Hearing Before the Senate Comm. on Foreign Relations, 105th Cong. 48-51 (1997) (statement of Harry Wu, Executive Director, Laogai Research Foundation) (describing use of forced labor in Laogai camps to produce goods imported by American corporations); Melissa Pearson Frugé, Comment, The Laogai and Violations of International Human Rights Law: A Mandate for the Laogai Charter, 38 Santa Clara L. Rev. 473, 473 (1998) (describing Laogai prison camps as "principally a tool for communist political coercion, which operates by means of forced, or slave, labor").

253. See Amnesty International, People's Republic of China: Gross Human Rights Violations Continue 10-11 (1996), available at http://web.amnesty.org/aidoc/aidoc_pdf. nsf/index/ASA170171996ENGLISH/\$File/ASA1701796.pdf (detailing unfair trial practices in China, including no presumption of innocence, limited right to conduct defense, and pervasive political pressure) (on file with the Columbia Law Review). 
assess the fairness of the proceedings that produced a foreign judgment for which U.S. recognition is requested. ${ }^{254}$ But in the criminal context, the act of state doctrine might prevent a U.S. court from questioning the processes by which a foreign national has been prosecuted. ${ }^{255}$ This result has obtained in a case involving deportation by Swiss authorities ${ }^{256}$ and finds support in the Restatement of Foreign Relations. ${ }^{257}$ Even if it might be thought to apply, however, the act of state doctrine does not enjoy constitutional foundations. ${ }^{258}$ A forced laborer could still argue that the Thirteenth Amendment supersedes that doctrine and empowers a U.S. court to assess the fundamental fairness of a criminal conviction offered as justification for his enslavement. ${ }^{259}$ These issues will merit further attention as the doctrine of multinational slave labor evolves.

254. Unif. Foreign Money-Judgments Recognition Act §4, 13 U.L.A. 268 (1986) (foreign money judgment is not enforceable if tribunal was not impartial or procedures otherwise did not comport with minimal due process requirements); Restatement (Second) of Conflict of Laws $\$ 98$ (1971) ("A valid judgment rendered in a foreign nation after a fair trial in a contested proceeding will be recognized in the United States so far as the immediate parties and the underlying cause of action are concerned." (emphasis added)); cf. Kremer v. Chem. Constr. Corp., 456 U.S. 461, 467-70, 481-83 (1982) (applying similar standard for according full faith and credit to U.S. judgments). See generally Courtland H. Peterson, Foreign Country Judgments and the Second Restatement of Conflict of Laws, 72 Colum. L. Rev. 220 (1972) (evaluating the Second Restatement's approach to foreign judgments).

255. The "classic American statement of the act of state doctrine," according to the Court in Banco Nacional de Cuba v. Sabbatino, provides:

Every sovereign State is bound to respect the independence of every other sovereign State, and the courts of one country will not sit in judgment on the acts of the government of another done within its own territory. Redress of grievances by reason of such acts must be obtained through the means open to be availed of by sovereign powers as between themselves.

376 U.S. 398, 416 (1964) (quoting Underhill v. Hernandez, 168 U.S. 250, 252 (1897)). 256. In Galu v. Swissair: Swiss Air Transp. Co., 873 F.2d 650, 654-55 (2d Cir. 1989), the Second Circuit disallowed a claim by a plaintiff seeking compensation from Swiss Air for its cooperation with Swiss police in forcibly deporting her. The Court explained:

The issue is whether the action taken against [the plaintiff] in removing her to the United States was an action that had been ordered in the exercise of the sovereign authority of Switzerland, or whether it was simply an ad hoc decision of local police officers. The burden is on the defendant to establish foreign law to the extent necessary to demonstrate its entitlement to the act of state defense. Evidence of foreign law is required not to determine whether the forcible removal . . . was lawful but whether it was in fact an act of state.

Id. at 654 .

257. See Restatement (Third) of the Foreign Relations Law of the United States $\S 443$, cmt. i (1987) [hereinafter Restatement (Third) of Foreign Relations] (stating that act of state doctrine applies to conduct plainly authorized or required by foreign law).

258. Sabbatino, 376 U.S. at 427 ("[T] he act of state doctrine is a principle of decision binding on federal and state courts alike but compelled by neither international law nor the Constitution .....").

259. Cf. Anne-Marie Burley, Law Among Liberal States: Liberal Internationalism and the Act of State Doctrine, 92 Colum. L. Rev. 1907, 1910-12 (1992) (arguing that act of state doctrine does, and should, operate differently depending upon the identity of the country involved). 
III. Jurisdiction and Extraterritoriality in Global Slavery Disputes

Thus far, I have not discussed the Thirteenth Amendment's application to the foreign slave practices of U.S. corporations as an "extraterritorial" doctrine. The choice has been deliberate. At the beginning of this Article, I framed the discussion to follow with the proposition that the knowing use of slave labor by U.S.-based entities in their foreign operations constitutes the presence of "slavery" within the United States, as that term is used in the Thirteenth Amendment. The practice of slavery, in other words, is impermissibly present in the territorial and political community of the United States whenever a U.S. citizen intentionally participates in that practice or devotes U.S. industry to facilitating it. Slavery, I contend, is distinctive in this respect. The judicial treatment that slavery and forced labor have received is qualitatively different from that received by other private activities-like discrimination, or anticompetitive activity - that are subject to the prohibitory authority of American law. ${ }^{260}$ Indeed, one of the questions that the foregoing analysis raises is whether this distinctive judicial treatment of slavery is purely a legal response to historical fact-the Thirteenth Amendment is special simply because the history of slavery in America was special-or whether the judicial cognizance that American courts have taken of slavery's interpersonal, institutional, and industrial features reflects deeper, transcontextual facts about the ontology of forced labor. This is an important question, and worthy of further inquiry.

Moreover, there can be no doubt that American participation in the trading of slaves abroad has been prohibited, first by statutes that preceded the passage of the Thirteenth Amendment, and later by statutes passed to enforce its proscription. ${ }^{261}$ Illicit U.S. participation in the foreign slave trade was one of the principal dramas of the American experience with slavery in the nineteenth century, ${ }^{262}$ and, I argue, it was one of the evils at which the Thirteenth Amendment was aimed. The issue remained salient following the Civil War, as the trade in slaves continued in Brazil and the West Indies for some years. ${ }^{263}$ In this respect, the Thirteenth Amendment and its implementing statutes have always had "extraterritorial" application. The doctrines explored above hardly trod upon unexplored terrain.

All of that said, it is still appropriate to ask how the application of the Thirteenth Amendment to the foreign slave practices of modern U.S. cor-

260. See, e.g., EEOC v. Arabian Am. Oil Co., 499 U.S. 244, 259 (1991) (denying extraterritorial effect to federal antidiscrimination law); United States v. Aluminum Co. of Am., 148 F.2d 416, 443-44 (2d Cir. 1945) (Hand, J.) (setting forth "effects test" for application of U.S. antitrust laws to foreign activity).

261. 18 U.S.C. $\$ 1582$ (1994) (prohibiting participation of U.S. citizens in foreign slave trade); id. $\$ 1585$ (prohibiting sale of slaves in foreign slave trade); see also supra text accompanying notes 164-168 (discussing pre-Amendment statutory prohibition).

262. See supra Part II.A.2.

263. Thomas, supra note 162, at 769-90. 
porations fares under the established doctrines for determining the extraterritorial effect of U.S. laws. The short answer is, quite well-the application of the Thirteenth Amendment explored above is not only allowable under, but indicated by, established extraterritoriality doctrines. But the path to that conclusion requires a number of turns, for the Thirteenth Amendment poses some distinctive interpretive challenges to accepted extraterritoriality doctrines.

\section{A. Extraterritoriality and the Thirteenth Amendment}

As an initial matter, it is clear that the application of the Thirteenth Amendment to the foreign slave practices of U.S. entities is a permissible exercise of prescriptive jurisdiction. The doctrine of national jurisdiction permits a sovereign to apply its laws to the activities of its own citizens and residents, wherever undertaken. ${ }^{264}$ While the Restatement of Foreign Relations characterizes national jurisdiction as an "exceptional" doctrine, ${ }^{265}$ it is a widely accepted alternative to territoriality and has been repeatedly recognized both in the U.S. and abroad. ${ }^{266}$ (This basis of prescriptive jurisdiction, as all others, is generally understood to operate subject to a "reasonableness" requirement, an issue to which I will return presently.) ${ }^{267}$ The more pertinent question is whether it is appropriate, under traditional doctrines of extraterritoriality, to authorize such an application of the Thirteenth Amendment.

Broadly speaking, cases addressing the extraterritorial reach of U.S. constitutional provisions are concerned with restraining the activities that U.S. authorities undertake abroad. ${ }^{268}$ This concern is a natural conse-

264. See, e.g., United States v. Yunis, 681 F. Supp. 896, 899-903 (D.D.C. 1988) (describing bases for prescriptive jurisdiction).

265. Restatement (Third) of Foreign Relations, supra note 257, $\$ 402 \mathrm{cmt}$. b ("Territoriality is considered the normal, and nationality an exceptional, basis for the exercise of jurisdiction.”).

266. See, e.g., Blackmer v. United States, 284 U.S. 421, 436-38 (1932) (upholding service of subpoena on U.S. citizen in France based on nationality). Professor Neuman explains that the expansion of nationality as a basis for prescriptive jurisdiction paralleled the United States' rise as a superpower following World War I. Neuman, supra note 23, at 965.

267. Restatement (Third) of Foreign Relations, supra note 257, § 403(1) ("Even when one of the bases for jurisdiction under $\S 402$ is present, a state may not exercise jurisdiction to prescribe law with respect to a person or activity having connections with another state when the exercise of such jurisdiction is unreasonable."); id. § 403(2) (listing factors to consider in determining reasonableness).

268. See, e.g., United States v. Verdugo-Urquidez, 494 U.S. 259, 274-75 (1990) (denying extraterritorial effect to Fourth Amendment where agents of U.S. Drug Enforcement Agency, working in tandem with local Mexican officials, searched without warrant homes of Mexican citizens suspected of dealing drugs); Johnson v. Eisentrager, 339 U.S. 763, 784-85 (1950) (denying extraterritorial effect to Fifth Amendment where U.S. officials imprisoned foreign "enemy aliens" in Germany following World War II); United States v. Bin Laden, 132 F. Supp. 2d 168, 185 (S.D.N.Y. 2001) (extending Fifth Amendment protections against self incrimination to foreign national interrogated by U.S. officials in conjunction with local law enforcement in Kenya). 
quence of the substantive scope of most constitutional provisions. Because they contain a state action requirement, the question of their extraterritorial effect usually arises only where the State has acted abroad, through its agents. Because constitutional provisions are generally prohibitory in nature, these questions usually involve attempts by petitioners to restrain the actions of the State. ${ }^{269}$ This focus stands in contrast to cases addressing the extraterritorial reach of federal statutes. ${ }^{270}$ Once again, this is a natural consequence of the substantive scope of most statutes, which often make no reference to state action and are principally directed at regulating the conduct of business in the private sector.

The Thirteenth Amendment embodies a singular exception to this neatly divided framework. Because it contains no state action requirement, the Amendment both restrains the actions of the State and regulates the activities of private individuals, imposing, as I put it earlier, selfexecuting, substantive limitations on private social and economic relationships. ${ }^{271}$ In other words, the Thirteenth Amendment exhibits both the characteristics of a constitutional provision and, in some respects, those of a statute. Consequently, the Amendment implicates aspects of both forms of extraterritoriality analysis: that traditionally applied to constitutional provisions and that usually reserved for legislative enactments.

1. Textual Arguments. - For a textual analysis of the Thirteenth Amendment, it remains appropriate to look primarily to the line of cases construing the extraterritorial reach of other constitutional amendments. ${ }^{272}$ Where statutes are concerned, the Supreme Court has required that Congress "clearly express" an "affirmative intention" to extend the reach of its enactments beyond U.S. borders. ${ }^{273}$ This may be an appropriate requirement for legislative enactments, in which Congress frequently attempts to set forth a regulatory scheme that is comprehensive in scope and can be amended or adjusted through subsequent legislation as needed. But it ill fits interpretation of the Constitution, no part of which expresses such an intent, and which in any event is constrained by different parameters. Most provisions of the Constitution are written in concise, broadly worded language embodying statements of principle

269. See Neuman, supra note 23, at 943.

270. See, e.g., United States v. Aluminum Co. of Am., 148 F.2d 416, 444 (2d Cir. 1945) (Hand, J.) (holding that U.S. antitrust laws apply to foreign activity that intentionally produces substantial effect in United States).

271. See supra Part I.A.

272. See authorities cited supra note 268.

273. EEOC v. Arabian Am. Oil Co., 499 U.S. 244, 248 (1991) (quoting Benz v. Compania Naviera Hidalgo, S.A., 353 U.S. 138, 147 (1957)). Some commentators have suggested that the Court's subsequent decision in Hartford Fire Ins. Co. v. California, 509 U.S. 764 (1993), may have relaxed this standard somewhat. See, e.g., Larry Kramer, Comment, Extraterritorial Application of American Law After the Insurance Antitrust Case: A Reply to Professors Lowenfeld and Trimble, 89 Am. J. Int'l L. 750, 750 (1995) (noting how Hartford could affect future litigation; specifically discussing Aramco, supra, and the role of comity). 
rather than exhaustive schemes of regulation, and, of course, their language cannot be changed or updated without employing the full process of amendment set forth in Article V.

Thus, the Court has looked to other textual indicators for guidance as to the proper application of constitutional provisions in multinational disputes. It has placed significant weight upon the Framers' choice of terms in describing the intended recipients of a provision's substantive protection-particularly their use of "the people" in some parts of the Constitution, and terms like "person" or "accused" in others. The Court has found in this textual variation an intention on the part of the Framers to reserve some constitutional protections to members of a territorially defined, national community. This view is set forth most clearly in United States $v$. Verdugo-Urquidez, in which the Court denied the request of a Mexican national to suppress evidence seized by DEA agents through warrantless searches undertaken in Mexico. ${ }^{274}$ Chief Justice Rehnquist explained:

[The Fourth Amendment], by contrast with the Fifth and Sixth Amendments, extends its reach only to "the people." ... . [This phrase] seems to have been a term of art employed in select parts of the Constitution. The Preamble declares that the Constitution is ordained and established by "the People of the United States." The Second Amendment protects "the right of the people to keep and bear Arms," and the Ninth and Tenth Amendments provide that certain rights and powers are retained by and reserved to "the people." While this textual exegesis is by no means conclusive, it suggests that "the people" protected by the Fourth Amendment ... refers to a class of persons who are part of a national community or who have otherwise developed sufficient connection with this country to be considered part of that community. The language of these Amendments contrasts with the words "person" and "accused" used in the Fifth and Sixth Amendments regulating procedure in criminal cases. ${ }^{275}$

The Framers' use of the more ecumenical "no person" construction in some provisions, the Court has concluded, lends itself more readily to application in cases involving claimants outside the political community of the United States. ${ }^{276}$ Judge Leonard Sand recently relied upon these textual arguments in his much noted ruling that U.S. law enforcement agents who operate in foreign countries must satisfy the requirements of

274. United States v. Verdugo-Urquidez, 494 U.S. 259, 274-75 (1990).

275. Id. at 265-66 (citations omitted).

276. One may well question whether the Framers themselves would have placed any such interpretation upon this choice of words, as Professor Neuman has argued. See Neuman, supra note 23, at 980 ("[T] he drafting of the Bill of Rights reflected inattention to the problematics of government activity abroad rather than a conscious effort to design entitlements solely for application within the territory ...."). 
Miranda when they interrogate criminal suspects, regardless of the suspects' nationality. 277

This line of argument lends strong support to the application of the Thirteenth Amendment to the foreign slave practices of U.S. entities. The Amendment proscribes, not merely the enslavement of persons, but the practice of slavery in its entirety. Had the drafters of the Amendment wished to limit the scope of the Amendment to the enslavement of members of the American political community, they could have provided that "The right of the people to be free from slavery or involuntary servitude shall not be violated." 278 Had they wished to limit the substantive scope of the Amendment to prohibitions on physically enslaved individuals, the drafters could have specified those individuals by providing that "No person shall be subjected to slavery, nor to involuntary servitude" 279 —as, indeed, they did in drafting the Fourteenth Amendment. ${ }^{280}$ Instead, the drafters chose distinctively capacious language, sweeping in the entire institution of slavery and all its components: "Neither slavery nor involuntary servitude ... shall exist ...."281 The drafters of the Amendment sought to extirpate the practice of slavery from the United States, root and branch, and they chose language that would reach all of its multiple layers.

Another textual issue in the Thirteenth Amendment also deserves attention. The Amendment provides that slavery shall not exist "within

277. United States v. Bin Laden, 132 F. Supp. 2d 168, 181 (S.D.N.Y. 2001). Indeed, Judge Sand offered the textual argument as the starting point of his analysis: We turn first to the expansive language used in the Fifth Amendment itself.

Its criminal procedure provisions are that:

No person shall be held to answer for a capital, or otherwise infamous crime, unless on a presentment or indictment of a Grand Jury, except in cases arising in the land or naval forces, or in the Militia, when in actual service in time of War or public danger; nor shall any person be subject for the same offence to be twice put in jeopardy of life or limb; nor shall be compelled in any criminal case to be a witness against himself, nor be deprived of life, liberty, or property, without due process of law.

The crucial phrase is "no person" and it neither denotes nor connotes any limitation in scope, in marked contrast to the use of "the people" in most of the other Amendments contained within the Bill of Rights.

Id. at 183 (citations omitted).

278. I invite comparison here to the Fourth Amendment: "The right of the people to be secure in their persons, houses, papers, and effects, against unreasonable searches and seizures, shall not be violated ...." U.S. Const. amend. IV.

279. And here, I invite comparison with the Fifth Amendment. See supra note 277. 280. See U.S. Const. amend. XIV, $§ 1$ ("No State shall . . . deprive any person of life, liberty, or property, without due process of law; nor deny to any person within its jurisdiction the equal protection of the laws.").

281. Id. amend. XIII, $\S 1$. The same textual argument would presumably apply to the protections conferred by both the Third and Eighth Amendments. See id. amend. III ("No Soldier shall, in time of peace be quartered in any house, without the consent of the Owner, nor in time of war, but in a manner to be prescribed by law."); id. amend. VIII ("Excessive bail shall not be required, nor excessive fines imposed, nor cruel and unusual punishments inflicted.”). 
the United States, or any place subject to their jurisdiction." Does this clause bear on the interpretive question, either as a term of expansion or of limitation? The only construction that the Court has given these words, in dictum, is equivocal on the point. In Downes v. Bidwell-one of the "notorious Insular Cases"282- the Court held that the Constitution's uniform taxation requirement does not apply to the Commonwealth of $\mathrm{Pu}$ erto Rico because the Framers, in specifying that "all Duties, Imposts and Excises shall be uniform throughout the United States," ${ }^{283}$ had intended the provision to apply only to the states themselves and not to other U.S. territories and possessions. ${ }^{284}$ The disposition of the Court resulted from two opinions, neither one of which garnered a majority. In the lead opinion, Justice Brown, writing only for himself, read the language of the Thirteenth Amendment expressly to include territories and other U.S. possessions (like Puerto Rico) within its scope. He invoked the Amendment to draw a contrast with the language in the uniform taxation clause, which refers only to "the United States":

The Thirteenth Amendment to the Constitution, prohibiting slavery and involuntary servitude "within the United States, or in any place subject to their jurisdiction," is also significant as showing that there may be places within the jurisdiction of the United States that are no part of the Union. To say that the phraseology of this amendment was due to the fact that it was intended to prohibit slavery in the seceded States, under a possible interpretation that those States were no longer a part of the Union, is to confess the very point in issue, since it involves an admission that, if these States were not a part of the Union they were still subject to the jurisdiction of the United States. ${ }^{285}$

Justice White, joined by two others, concurred in the result reached by the lead opinion, though differing significantly in his approach to the uniform taxation question. On the significance of the Thirteenth Amendment, however, White was in agreement:

In concluding my appreciation of the history of the government attention is called to the Thirteenth Amendment to the Constitution, which to my mind seems to be conclusive. The first section of the amendment, the italics being mine, reads as follows: "Sec. 1. Neither slavery nor involuntary servitude, except as a punishment for crime, whereof the party shall have been duly convicted, shall exist within the United States, or any place subject to their jurisdiction." Obviously this provision recognized that there may be places subject to the jurisdiction of the United States but which are not incorporated into it, and hence are not 
within the United States in the completest sense of those words. ${ }^{286}$

Lastly, the four dissenters were of the view that the Thirteenth Amendment would have applied to U.S. territories without the addition of that phrase, and they concluded that it had merely been added "out of abundant caution" and was entitled to "little weight." 287

I have reproduced these passages at length because they are the only treatment that the Court has given to the Thirteenth Amendment's reference to "jurisdiction," but they seem to me to have little bearing on the present question. The slavery doctrine explored in this Article embraces a clear territorial nexus-it is U.S. entities, exploiting slave labor in their foreign operations, that the doctrine reaches. It is an "extraterritorial" doctrine in that it may be triggered by abuses occurring abroad, but it is the participation of U.S. entities in the practice of slavery that offends the Amendment's substantive prohibition. The dicta in Downes v. Bidwell simply make it clear that a corporation cannot shield its slave activities from Thirteenth Amendment scrutiny by relocating to the Commonwealth of Puerto Rico; they do not purport to speak to the range of activities that the Amendment reaches when undertaken by U.S. entities. Thus, the Amendment's reference to "jurisdiction" neither confines it absolutely to domestic territory in all its applications-a result already foreclosed by the slave trade issue-nor expands the Amendment's reach to the fullest extent of prescriptive jurisdiction allowable. Rather, it is cases like Verdugo-Urquidez that provide the textual approach to addressing this question. Those cases indicate that the choice of language in the Thirteenth Amendment firmly supports the slavery doctrine explored above.

2. Multilateral Considerations. - When domestic law regulates the activities of private actors operating outside its territorial borders, we must ordinarily ask whether such regulation runs afoul of limitations embodied in private international law or principles of comity. In some respects, those inquiries do not fit neatly into an examination of a constitutional provision. Rules of international law enter American disputes as federal common law. ${ }^{288}$ When federal statutes are analyzed in light of international law principles, the relevant inquiry is whether the general presumption that Congress legislates consistently with these common law principles is overcome in a particular case. ${ }^{289}$ While one could, in theory,

286. Id. at 336-37 (White, J., concurring).

287. Id. at 358 (Fuller, J., dissenting).

288. See, e.g., Restatement (Third) of Foreign Relations, supra note 257, at $\S 111$ cmt. d (noting that international law enters as federal common law); Lea Brilmayer, Federalism, State Authority, and the Preemptive Power of International Law, 1994 Sup. Ct. Rev. 295, 295, 302-04 (1994) (discussing post-Erie consensus that international law enters America as federal common law). But see Curtis A. Bradley \& Jack L. Goldsmith, Customary International Law as Federal Common Law: A Critique of the Modern Position, 110 Harv. L. Rev. 815, 816-21 (1997) (challenging received view that international law enters American legal system as federal common law).

289. Chief Justice Marshall's early statement of the doctrine remains canonical: 
ask the same type of question about the scope of a constitutional provision, the Constitution does not generally bow to inconsistent common law principles. Even so, it may be useful to ask whether a proposed application of a constitutional provision is consistent with such principles.

Broadly speaking, once a domestic court has determined that its laws were intended to have extraterritorial effect, international limitations call upon the court to address two sets of concerns: the private interests of the regulated parties, and the potentially competing public policies of sovereign entities and the international community. The private interests of regulated parties primarily entail the existence of justified party expectations. ${ }^{290}$ Thus, for example, if the legitimate business planning efforts of a corporation would be frustrated by legal regulations that the company could not reasonably have anticipated would apply, this might militate against extraterritoriality. ${ }^{291}$ The potentially competing public policies of sovereigns come into play when extraterritoriality might subject a private entity to inconsistent or conflicting legal regulations. ${ }^{292}$ In a typical case, a sovereign might find that its regulatory policies have been effectively displaced by the threat that another sovereign will give extraterritorial effect to its own, stricter set of standards, causing a "race to the top" as companies seek to avoid liability. Once again, this is a signature issue in antitrust, where the broad application of comparatively restrictive American laws to multinational corporations threatens to displace local business regulations in other markets. ${ }^{293}$ In rare cases, multinational actors might actually find themselves subject to irresolvable conflicts, in which the laws of one state command them to take actions that are forbidden by the laws of another. In this narrow range of cases, the Supreme Court has suggested that principles of comity might call for an

[A]n act of congress ought never to be construed to violate the law of nations if any other possible construction remains, and consequently can never be construed to violate neutral rights, or to affect neutral commerce, further than is warranted by the law of nations as understood in this country.

Murray v. Schooner Charming Betsy, 6 U.S. (2 Cranch) 64, 118 (1804) (Marshall, C.J.).

290. See, e.g., Restatement (Third) of Foreign Relations, supra note 257, § 403(2) (d) (looking to "the existence of justified expectations that might be protected or hurt by the regulation").

291. See Timberlane Lumber Co. v. Bank of Am., N.T. \& S.A., 549 F.2d 597, 611-13 (9th Cir. 1977) (describing range of interests to consider in defining extraterritorial scope of federal antitrust statute).

292. See, e.g., Restatement (Third) of Foreign Relations, supra note 257, § 403(2) (g) (looking to "the extent to which another state may have an interest in regulating the activity"); id. § 403(2) (h) (looking to "the likelihood of conflict with regulation by another state").

293. See, e.g., Foreign Trade Antitrust Improvements Act of 1982, 15 U.S.C. $§ 6$ a (1994) (limiting application of antitrust laws to conduct that "has a direct, substantial, and reasonably foreseeable effect" on domestic or export commerce); Den Norske Stats Oljeselskap AS v. HeereMac Vof, 241 F.3d 420, 428-29 (5th Cir. 2001) (holding that FTAIA is intended to exempt "purely foreign transactions" from U.S. antitrust laws). 
extraterritorial application of U.S. law to bow to foreign policies. ${ }^{294}$ While approaches to the question vary considerably, ${ }^{295}$ most courts and commentators agree that extraterritorial analysis should proceed with these multilateral policy concerns in mind. ${ }^{296}$

Both the private and the public interests associated with avoiding potential conflicts with competing sources of foreign law are considerably reduced in the slavery doctrine explored in this Article. The prohibition of slavery has been recognized as a peremptory norm of international law. ${ }^{297}$ The basic policy prohibiting the exploitation of slave labor is thus universally applicable, governing both states and private actors, and local municipal laws in conflict with that policy are presumptively invalid. In effect, when a nation gives extraterritorial effect to a provision like the Thirteenth Amendment, it is providing an enforcement mechanism for a principle of international law that already underlies all multinational transactions. That being so, the danger of a conflict with legitimate private or sovereign interests is greatly reduced. Indeed, as Professor Joel Paul has explained, the doctrine of comity arose in large part as a response to legalized slavery, as a means of permitting free jurisdictions to resist the intrusion of slavery into their territory. ${ }^{298}$ It would constitute a significant reversal to apply the doctrine in a fashion that would facilitate such an intrusion. One can imagine conflicts in the particular schemes chosen by different sovereigns to enforce the abolitionist norm. If such conflicts arise, they may warrant further examination. But a nation's policy seeking to tolerate or promote local slave practices would receive no solicitude in multinational disputes, whether considered under international law or principles of comity.

294. See Hartford Fire Ins. Co. v. California, 509 U.S. 764, 799 (1993) (holding by implication that deference to foreign law under comity principles may be appropriate "where a person subject to regulation by two states [cannot] comply with the laws of both" (quoting Restatement (Third) of Foreign Relations, supra note 257, § $403 \mathrm{cmt}$. e)).

295. Compare id. at 794-99 (looking to direct and substantial domestic effects), and United States v. Aluminum Co. of Am., 148 F.2d 416, 443-45 (2d Cir. 1945) (Hand, J.) (same), with Timberlane Lumber, 549 F.2d at 613-15 (looking to totality of factors and interests of competing sovereigns).

296. Most, but not all. Professor Dodge, for example, has argued that courts should determine the extraterritorial effect of domestic laws without reference to any such concerns: "I argue that a court should apply a statute extraterritorially whenever doing so appears to advance the purposes of the statute and should not worry about resolving conflicts of jurisdiction with other nations." William S. Dodge, Extraterritoriality and Conflict-of-Laws Theory: An Argument for Judicial Unilateralism, 39 Harv. Int'l L.J. 101, 104-05 (1998).

297. See supra note 31.

298. Joel R. Paul, Comity in International Law, 32 Harv. Int'l L.J. 1, 12 (1991) ("[Lord] Mansfield and especially [Justice] Story saw comity as a principle that allowed free and slave states to coexist without requiring the courts of free states to apply the laws of slavery.”) 


\section{B. Early Evidence?}

There is one tantalizing piece of early evidence concerning the impact that the drafters intended the Thirteenth Amendment to have upon the foreign slave practices of U.S. citizens. In 1871, six years after the ratification of the Amendment, Congressman Nathaniel Banks of Massachusetts introduced a bill into the House of Representatives. ${ }^{299}$ It was entitled "A bill to carry into effect article thirteen of [the amendments to] the Constitution of the United States, and to prohibit the owning or dealing in slaves by American citizens in foreign countries." 300 Like most other statutes passed under the Thirteenth Amendment's enforcement clause (before and since), it was a criminal statute. ${ }^{301}$ Banks presented the bill to the Committee on Foreign Affairs, where it was read twice, ordered to be printed, ${ }^{302}$ and then, apparently, died in committee. The New York Times contemporaneously noted its introduction, without further discussion, as one entry on a list detailing recent legislative activity. ${ }^{303}$ The proposed bill reads, in its entirety, as follows:

Be it enacted by the Senate and the House of Representatives of the United States of America in Congress assembled, That if any citizen of the United States shall own or be directly or indirectly, as lessor or lessee, as mortgagor or mortgagee, as assignor or assignee, or otherwise, interested in slaves, or in persons held in involuntary servitude, except as a punishment for crime, whereof the party shall have been duly convicted, he shall be deemed guilty of a high misdemeanor, and shall be liable to be prosecuted therefor before any circuit or district court of the United States, and being convicted thereof shall be fined not exceeding thousand dollars, and be imprisoned for not less than nor more than years.

Sec. 2. That no citizen of the United States who shall own, or be directly or indirectly, as lessor or lessee, as mortgagor or mortgagee, as assignor or assignee, or otherwise, interested in slaves, or in persons held in involuntary servitude, except as punishment for crime, whereof the party shall have been duly convicted, shall receive, or be entitled to receive, any protection whatever from the Government of the United States, or from

299. Cong. Globe, 42d Cong., 2d Sess. 55 (1871).

300. H.R. 490, 42d Cong. (1871).

301. See supra note 30. The Federal Anti-Peonage Act, 42 U.S.C. $§ 1994$ (1994), is the exception. As mentioned earlier, that statute abolishes all peonage schemes and was aimed at the state-sanctioned practices discussed in Part I. See supra notes 39-50 and accompanying text.

While it is possible that an individual could maintain a private right of action for damages under $\$ 1994$, there does not appear to be a reported case in which an individual has successfully done so. Cf. Whitner v. Davis, 410 F.2d 24, 30 (9th Cir. 1969) (assuming possibility of private right of action for peonage but dismissing for failure to state a claim); Bryant v. Donnell, 239 F. Supp. 681, 684-85 (W.D. Tenn. 1965) (same).

302. Cong. Globe, 42d Cong., 2d Sess. 55 (1871).

303. House of Representatives, N.Y. Times, Dec. 12, 1871, at 5. 


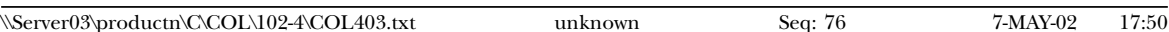

any officer thereof, against, or on account of, any act or acts committed against him, or against his property of any kind, without and beyond the jurisdiction of the United States.

Sec. 3. That before any alien shall be admitted to become a citizen of the United States, he shall declare on oath or affirmation before the supreme, superior, district, or circuit court of some one of the States, or of the territorial districts of the United States, or before any court of record in any individual State having common-law jurisdiction and a seal and clerk or prothonotary, or before a circuit or district court of the United States, that he does not own and is not directly or indirectly, as lessor or lessee, as mortgagor or mortgagee, as assignor or assignee, or otherwise, interested in slaves, or in persons held in involuntary servitude, except as a punishment for crime of which the party shall have been duly convicted. ${ }^{304}$

In this bill may be seen much of the American experience with slavery examined throughout this Article. The bill proposes to carry into effect the elimination of the entire social relation of slavery by criminalizing the status of "master," irrespective of the physical location of the enslaved individual. It recognizes the role of "indirect" offenders in supporting the institution of slavery and imposes criminal sanctions of sweeping breadth to catch them within its net, reaching anyone who is "directly or indirectly . . . interested in slaves, or in persons held in involuntary servitude." And it provides a reminder of the worldwide industry in slave labor that continued to thrive in Africa, Latin America, and parts of Europe even following its official eradication in the United Statesand that continues to thrive today. ${ }^{305}$

The value of this proposed statute in determining the content of a modern Thirteenth Amendment jurisprudence is unavoidably ambiguous. A skeptic might argue that we should interpret the Committee on Foreign Affairs' failure to act on the bill as evidence that the bill exceeded the substantive scope intended for the Amendment, though there appears to be no evidence to support that conclusion. I take the bill as further confirmation that the drafters of the Amendment, steeped in the multilayered practice of slavery, understood that slavery could not be eradicated from American society and industry without reaching all the slave activities of U.S. citizens, both at home and abroad. For me, the failure of the bill to gain passage is best explained as a failure of political will. In the case of the foreign slave trade, criminal sanctions were already in place when the Thirteenth Amendment was ratified that prohibited any form of American participation in the practice here or abroad, and the country had already had over fifty years of official proscription and ten years of active prohibition in which to become accustomed to those sanctions. ${ }^{306}$ "Slave traders" had long since become the designated

304. H.R. 490, 42d Cong. (1871).

305. See supra Part I.B.

306. See supra Part II.A.2. 
bugbears of the unstable practice of American slavery. ${ }^{307}$ But even following the Civil War, significant economic interests in both the North and the South continued to be intimately intertwined with slave labor around the world, and recent slave owners, far from being prosecuted or vilified, were being invited back as full participants in the national political community. Banks's sweeping antislavery bill-subjecting a transgressing U.S. citizen to criminal sanction and dramatically denying him "any protection whatever from the Government of the United States . . . [for] any act or acts committed against him, or against his property of any kind, without and beyond the jurisdiction of the United States"-was too much, too soon. America may have been prepared to acknowledge that the newly enacted Amendment forbade foreign slave practices in principle, but not to back that principle with the threat of criminal sanctions.

Thus, the bill stands as an artifact. It is a point of articulation that reveals, even if it does not alone embody, the vocabulary of principles that characterize its time. The bill aids therefore in discerning "the essential feature $[\mathrm{s}]$ of the slavery that the Thirteenth Amendment commands us to disestablish." 308

\section{ConClusion}

Any attempt to articulate a modern Thirteenth Amendment jurisprudence that is both coherent and relevant to modern industrial conditions must grapple with history. The drafters of the Reconstruction Amendments employed broad language, untethered to the historical moment in which they wrote. That very open-endedness demands clear statements of principle to guide our interpretation, and the search for those principles must be informed by the full measure of America's experience with slavery. The Court has traveled this road, if slowly and imperfectly, in the development of its Fourteenth Amendment jurisprudence. One of the great triumphs of Brown was its transformation of the American history of state sanctioned racial oppression from a tool of subjugation, as it had been in Plessy, into one of liberation. Recent retrenchments in the Court's equality jurisprudence have dimmed the luster of this triumph, 309 but they will not reverse it.

The time has come for the Thirteenth Amendment to travel a similar path. The experience of slavery in America was an institutionalized af-

307. See, e.g., Peter Kolchin, American Slavery 1619-1877, at 98 (1994) ("Although the slave trade was extremely lucrative . . . it was never entirely respectable."); George Shepperson, Comment, in Stanley L. Engerman \& Eugene D. Genovese, Race and Slavery in the Western Hemisphere: Quantitative Studies 99, 103 (1975) (describing low social status of those involved in slave trade).

308. Binder, supra note 5, at 2068.

309. See Adarand Constructors, Inc. v. Pena, 515 U.S. 200, 235 (1995) (holding that federal government must satisfy strict scrutiny when enacting race conscious remedial legislation); City of Richmond v. J.A. Croson Co., 488 U.S. 469, 498-506 (1989) (adopting strict evidentiary standards for race conscious remedial legislation). 
[Vol. 102:973

front that was multiple in its modes of operation and unimaginable in the harm that it caused. We would commit an unworthy mistake if we were to insist upon a fancied simplicity in construing the constitutional provision that sought to end that institution and prevent it from reappearing. The Supreme Court avoided that mistake once in the peonage cases of the early twentieth century. Now that the tragedy of slavery is again playing out with American participants, this time on an international stage, we must demonstrate a similar courage and vision when called upon to translate the principles embodied in the Amendment to the global industrial context. 